

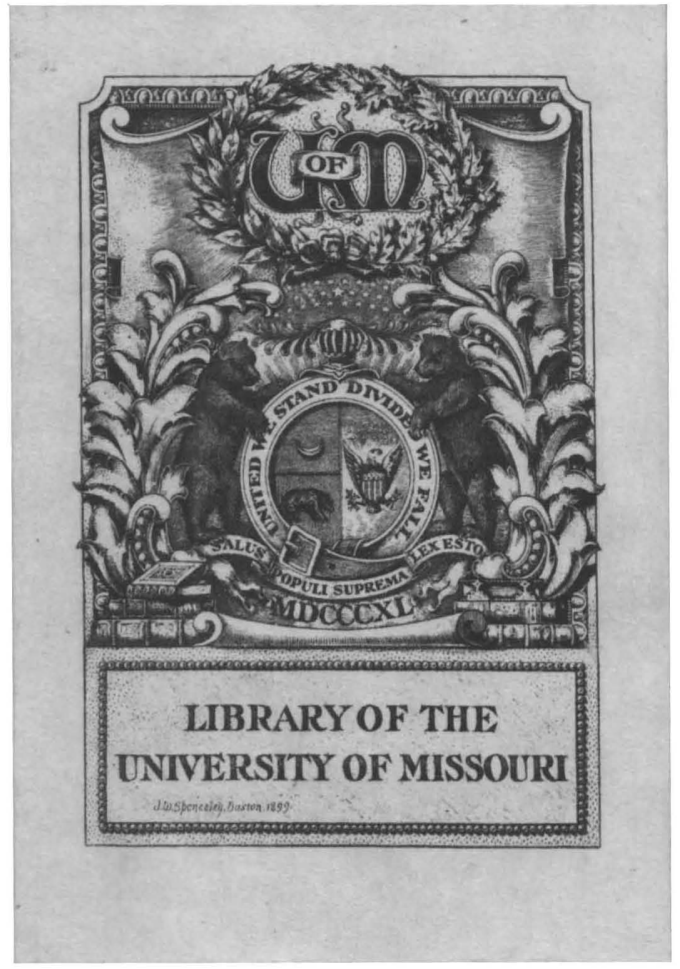

This Thesis Has Been

MICROFILMED

Negative No. T. $\quad 310$

Form 26 



\section{CONCRETES AND ABSTRACTS IN THE OLD \\ ENGLISH EPIC BEOWULF.}

by

Estella Faye Cratty, B.S. In Education

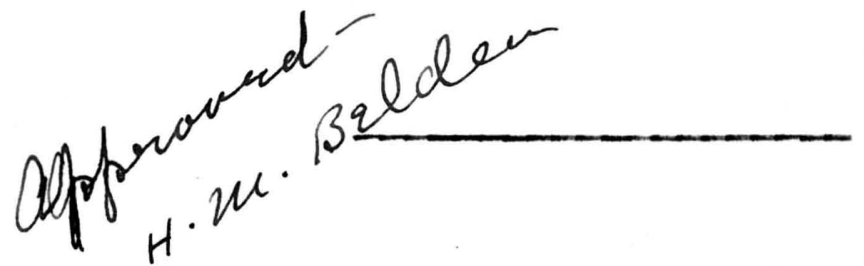

SUBMITTED IN PARTIAL FULFILMENT

OF THE REQUIREMENTS FOR THE

DEGREF OF MASTER OF ARTS

in the

GRADUATE SCHOOL

of the

UNIVERSITY OF MISSOURI. 
Table of Contents.

I. Introduction.

1. Definition of the Subject.

2. Statement of the Thesis.

II. Note on Subject Matter and Arrangement.

III. Presentation of the Various Groups of Terms.

A. Terms Denoting Persons.

B. Terms Denoting Groups of Persons.

C. Names of Living Creatures Other than Human Beings.

D. The Land, the Sea, and the Sky.

I. Review of Dr. Clark Hall'g Index of Things Mentioned in Beowlle.

F. Some Terms and Accounts of Action Which Give objectivity fo the Poem.

G. A few Very Vague Concretes and Some Abstrăcts of which the Beowulf Poet Seens Fond.

If. Conclusion.

v. Bibliography . 


\section{INTRODUCTION}

The terms concrete and abstract as used in this paper are largely terms of convenience. Where logicians are at daggers drawn the ordinary thinker may be pardoned if he goes his own way, riding his own choice of definitions. The concrete, here, then, is the sensible, the physical, the objective; the abstract is the spiritual, that which cannot be conceived as having physical existence. A concrete term is an electric button which flashes before the thousand eyes of the mind a full and rounded image; an abstract term calls up no image, but is the symbol of emotion or reflection, of a arawing away from physical limits. Mr. West* would refer the word "friendships" to the class concrete because "an abstract noun, so long as it remains abstract, cannot be used in the plural;" quality, which an abstract noun denotes, is "always one and the same, and therefore singular." But friendship, singular or plural, has no physical existence; one may perform friendly offices, which take on solid, substantial form, but one's friendship must always remain a thing of spirit.

The proof of the quality of the words is in the effect apon the mind. Goodness and whiteness and tallness may be

\footnotetext{
* English Grammar for Beginners p.23
} 
equally abstract, but their corresponding concretes are not equally concrete. We do not see a good man; we see a white man, a tall man. We cannot call up an image of a gentleman, but we can easily summon before our imagination an Indian chief, whom we may, when our admiration is aroused, declare to be a gentleman. In so naming him, our image is made no whit the clearer, we have simply changed our evaluation or our feeling attitude. The more individual, the more presentive the vocabulary is, the more deeply it pencils the exact outlines and limits of the figures, and the more it fills in and colors the outlines given, the more concrete is the effect. In proportion as the diction is general, vague, indeterminate, expressive and productive of emotion and reflection, is it abstract. Mr. Sidgwick says, * "It follows ... that all of them (general names) suffer from abstractness, however concrete be the things they denote. Indeed, the extent to which they suffer from it is wholly independent of the question whether the things denoted are concrete or not."

That poem may surely be said to be abstract in character in which the motive is more real than the deed, in which the thoughts of a man's heart are given more dramatic prominence than the facts of his appearance, in which few figures appear on the stage of action and little or no setting is provided, in which a wealth of terms results in

The Use of Words in Reasoning p 253-4 
comparatively little pictorial effect. It is my thesis that the foregoing description fits the Anglo-saxon epic, Beowulf.

With the delightfully expressive word "Innerlichkeit," Brandl* touches at once upon the chief characteristic of Beowulf.

"Wenig Anschauung, wie in aller Iiedepik der Germanen, aber zugleich viel Innerlichkeit, wie sie dort nicht entfernt entwickelt wurde, ist bezeichnend fur die Auffassungsweise in Beowulf and buch in den Walderefragmenten. Wie Beowulf aussieht, horen wir niemals; nur dass ihm die starke von areissig Mannern, innewohnte, wie keinem anderen sterblichen .... Das ist eine germanische Einseitigkeit, die auch der ags. Iyrik and der ganzen altn. Poesie eigen ist, im Gegensatz zu Homer, der die Köp̌per, Mienen, and Geberden seiner Helden plastisch ausbildet, und za Chaucer, der zuerst die Kleider und kleinsten Lebensgewohnheiten seiner Gestalten studierte. Aber mit einer weder in skandinavischer noch in griechischer Epik erfinabaren Warme werden die seelischen Empfindungen and stimmungen, die $A b-u n d ~ R t h c k s i c h t e n$, die Erinnerungen und Gebete des Gautenhelden behandelt; er wird umstandich gewarnt vor dem 'tbermut, den er gar nie hat; es wird ihm die klugheit and die Trosterkroft geweissagt, die er schon hat. Ebenso

\footnotetext{
* Geschichte der englischen Iiteratur p. 72
} 
wenig Husseres erfahren wir von Hrothgar, dem blondharigen und altersweisen, aber desto mehr von seinem Gemtlt ....... Selbst der zorn des Brachen, dem ein Becher vom Schatze weggestohlen wird, und die Untreua des berthmten Schwertes, das dem Herrn versagt ( $1525 \mathrm{ff})$, milssen uns nahe gehen."

The very beginning of the poem strikes the keynote:

"Hwaet! we Gar-dena in gear-dagum

peod-cyninga prym gefrunon

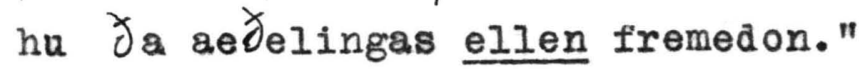

Two abstract terms in those three lines, bearing

the weight of emphasis in stress and significance! As it is in the beginning, so it is until the end. This paper will close with a long list covering only some of the abstract terms of which the Beowulf poet seems fond. Many of these ideas were so vivid and real to the poet as to become almost concrete and to necessitate free translation. Thus we say "they performed valorous deeds" because we feel that "ellen," as it stands, has assumed more force and definiteness than the abstract usually enjoys. But the "Innerlichkeit" is still evident; the poet has simply hit upon a device for saving it from loss of effect and suggestiveness in transmission. We see little of Grendel's raids, but we hear much of the trouble and anguish they entailed, of Hrodgar's "sorrow for his thegns." Even in warfare, terror and wrath are as much present as spears and shields. 
When men address each other they speak "a stately speech, such as grave Iivers ...... use," and large and solemn abstract terms are often in their mouths. When they tell each other stories, they dwell quite as much upon the thoughtful, the emotional aspects of the tale, as upon the details of the action. Hrodgar, telling Beowulf the story of Grendel's persecution, says, "It is a grief to me in my soul to tell any man what Grendel with his thoughts of hate has tramed for me in Heorot of harm and sudeen harassings. My chamber-guard, my warband is diminished. Wyrd swept them off into the fearsome toils of Grendel. Still God can easily restrain the wild ravager from his deeds."* Suddenly, however, as the memory of the past becomes cruelly vivia to him, he breaks out in a bit of concrete recollection, as an old man might, "Then at the morning time, when day shone forth, was this mead-hall, the chamber for retainers, stained with gore -- all the bench-boards deluged with blood, the hall with the gore of swords." That said, he recovers himself, to become general and vague again, as though he felt a dignity and restraint in the suppression of details. His speech to Beowulf after the successful issue of the fight with Grendel's mother is surprising to a degree. Where we look for congratulation

* Clark Hall's translation. 
and detailed planning for the tuture, we meet with one of the most extended reflective passages of the poem. These were a thoughtful people.

As Professor Brandl says, in the passage quoted before, the details of outward appearance are the least of the poet's concern. How Beowulf appeared to those who saw him we can guess only from the favorable impression which he immediately made upon Wulfgar. We surmise that he was a personable young man, but we do not know. only once is a woman called beautiful (3016). Of the beasts who are men's foes, little is shown, the point of interest being that they are creatures who hate, who plan crime, who are at enmity with God. Of the 433 different adjectives in Beowulf, only 129 could possibly be construed as physical in nature. Scheinert* shows 6 adjectives expressive of physical attributes of the hero, Beowulf, beside 28 of character and 21 of ability, tüchtigkeit. Not many clear physical realities appear on the scene of the narrative. To the end that it may appear how limited a view of this world is vouchsafed us in the poem, the following pages will present these groups of concrete terms as found in Beowulf:

A. Terms denoting persons

B. Terms denoting groups of persons

c. Nouns denoting living creatures, other than human beings

* DIe Adjektiva im Beowalf- epos als Darstellangsmittel 
D. The land, the sea, and the sky

E. A review of Clark Hall's Index of Things mentioned in Beowulf

F. Terms and accounts of action giving objectivity to the poem.

G. A few very vague concretes and some abstracts of which the Beowulf poet seems fond.

Much the longest list of those indicated above is the list of terms denoting persons. Here occur, especially, the kennings, the Germanic poetical device for securing variety and alliteration. From such a wealth of terms one expects to find many human figures, clearly pictured. But they do not appear. Most of these nouns are, as it were, adjective substitutes, noble names applying, for the most part, to a little group. They are usually very vague and general, very loosely applied, often mere occasional formations, intended to convey a compliment, to show the esteem in which a leader is held or the relation of a man to his fellows. Above all, the words are, I think, chosen as intensives, as re-inforcing an idea by repeating it in a new combination of vocables, to arouse in the hearts of the hearers that ardent hero-worship which the poet felt for his hero.

My country, the land of my fathers - Napoleon, gallant commander, bold leader of men in gattle - "Friends, 
Romans, Countrymen"--"ruler of the Bright-Danes, protector of the scyldings" (427-8)--in all of these is it not the emotional effect of the cumulation of terms which is sought? Only an outburt of stately-seeming. names can satisfy the pent-up aftection and rapturous admiration in the heart of the narrator of Beowult's story. There is no denying that he loved his hero. Conversely, he hated Grendel with all his heart, and bestowed upon him approbious terms,--not childish epithets of hate, but words of solemn and awful generality, which fill one with loathing toward the evil spirit, while hiding forever the beast from view. The concrete terms, then, I have chosen to consider as they actually occur in Beowulf that it may appear how vague and general they are and how few true concretes the poet shows us. 
Note on subject Matter and Arrangement

The study here is of nouns. The adjectives Mr. Scheinert has already discussed, from a different point of view but with substantially the same result, in his dissertation Die Adjectiva im Beowulfepos als Darstellungsmittel. Some consideration of the verbs, so far fruitless, was cut short because the limits of the present study would not admit of including them.

One group of nouns in Beowulf has already been fully cataloged by Dr. John K. Clark Hall. His Index of Things Mentioned in Beowulf I have simply summarized to show its bearing upon the problem betore me. No attempt has been made here to rehearse all the items of his lists, since such rehearsal seemed quite futile.

For clearness' sake I want to make the following notes on arrangement:

1. The word 'only' placed in parenthesis atter a citation indicates that this is the only occurrence of the given word in Anglo-Saxon literature. The assumption is based on the quotations of Grein and Bosworth-Toller. For Section E., The Index of Things, however, no attempt has been made to ascertain whether the words occur elsewhere; hence the absence of the parenthetic 'only' there means nothing more than a lack of knowledge. 
2. The abbreviations of names of Anglo-Saxon poems follows the use in Grein's Sprach-schatz der angel+s dachsischen Dichter.

3. Gr. $=$ Grein, B. T. $=$ Bosworth-Toller (referring to the dictionaries prepared by these men), T.=Torp i. e. his Wortschatz der germanischen Spracheinheit; the latter is followed by the Primitive Germanic base given by Torp for the word in question.

4. The definition of the word is for the most part, a translation of that given by Grein. Iiberty has been taken to omit such definitions (where Grein gives two or three) as seem to have no significance for the word in Beowulf. Bosworth-Toller has served to show how the word has been used in prose.

5. After a dash or included within parentheses following a citation, the person or thing referred to is often indicated.

6. Citations are-made from Holder's edition of Beowulf, unless another editor is definitely named.

7. The abbreviation B. is omitted before a line number where an earlier citation has made it clear that the lines are quoted from the poem Beowulf. 


\section{A. Names of Persong.}

Khuge (Nominale Stam bieldungglehre der Altgermanisehen Dialekte) rates as "persenliche konkreta" old participles, nouns with a (0) - suffix as rinc, with 1- suffix as byre, with u suffix as Bote, with the oulfixes -ja, -jan, -an, -ila, -ana, -inga, - $p$, -mann, etc., as in feda, frea, scea fa, engel, peoden, cyning, haeled, gleoman, respecitvely. On the basis of his study, every is word in the lists to follow dou btless concreta.

Granting that, on the ground of logical classif1cation, they are concrete, one is surprised to discover how very few figures result from this rich vocabulaty of terms and how little one can vigualize the figures that do appear. To show this lack of concrete result, the words of this section have been divided on two principles: (1) class distinctions (2) descriptive character. Accordingly Group 1 contains the names of leaders; 2, dese criptive characters, telling some characteristic or duty of a chlef; (3) names of common men; (4) of warriors; of men of occupation other than warfare; (6) general names indicating nobility; (7) descriptive nouns indicating the character of men or their relation to others;
(8) nouns of kinship;
(9) terms for women. 


\section{Names for Persons.}

Before submitting the numerous groups of common nouns, which in Beowulf serve at once to furnish initial rhyme and to supply variation, to designate the actor in his action and to crown him with noble names, before these, it seems convenient to note turee special points: the apparent avoldance of the proper name, the use of adjectives, andy nouns, resembling participles, which have been called end-nouns.

It is particularly noteworthy that the common nouns occur almost to the exclusion of proper nouns. The name of Beowulf himself appears only 53 times; 8 of those instances are in address and 13 in formal phrase Beomulf madelode. From 1. 1474 to 1651 - the account of the fight with Grendel's mother - Beowulf is not mentioned once by name; he is Weder - Geata leod (1492), hilde-rince (1495), gumena sum (1499), gud-rinc (1501) se lool (1512), se goda (1518), se gist (1522). Contrast with such a passage the famous duel of Bk. 22 ot the Iliad where Hector and Achilles appear in their own proper name: "After Hector sped fleet $\mathrm{A}^{\mathrm{C}}$ illes." "For the life of horse-taming Hector was their race." Phoebus Apo110, bright-eyed Athene are named. It is an epic of individuals, the naming of whom focuses the light upon them as individuals. Beside them "the earl", "the good man", "the stranger" is a shadowy being. 
Horeover, before the common nouns, in giving an abstract character to the whole poem, stand a list of adjectives used as nouns which is given by Scheinert, * and an additional list of end-nouns which I have made.

Adjectives Used as Nouns.

Gruppe I: saemepe 325, deadfaeges 850, unlyfigendes 744, umborwesendum 1187, geong manig 854, geongun 7,ealdum 72. Gruppe II: beornas on blancum 856, hriagedstefna 32b. 1131, wunde *ैatefna 220; goldhodrê 614. - GruppeIII: hwaet... searohaebendra byrnum werede 237, cenra gehwylcum 768 b, se heard 401 b, heardra nan 888 , wiges heard 886 , heard under helme 342 , 405, heardhicgende 394, swit hicgende 1016, swid ferhdum 173, swidferhd e 493, swidferhdes sid 908, drydswid 131. 736b, headodeor 688, heactodeorum 772, hili edeor 312. 834, hof modigra 312b, modge 855, grim 555, w1sfoest 626. - Guppe IV: se aelnihtiga 92, se rica 3100 . 899, rice 1237, se yldesta 258, pone yldestan 363, holdra py laes 487b, p aes ladan 132, lap es 841, lađum 440.550, la pra naenig 242b, grames 765, $p$ a graman 777b, gramum 424.1034, weapum 660.78b, fara 578, unou $p$ es 660, ne leof ne lad 511, fela lap es 929 b, fela... leofes and lapes 1061. Gruppe v: se goda 205.355 .675 1190b,

* Die Adjectiva im Beowulfs Eposals Darstellungs mittel p.69 
paem godan 384 b, pa selestan 416, god mid Beatum 195, bealohydig 723, inwitdancum 749, haepenes 986 , hae penra 179. Gruppe VI: se maera 762, paem maeran 270, maerne 36, ellenrof 340,358, headorofe 864, higerofne 204, blaedagende 1013 b, widcup es 1042, prydum dealle 493, sigehrepig 94, t1x-leases 843. Gruppe VII XI: dreama leas $850 \mathrm{~b}$, dream healdende 1237b, for laessan (ntr) 951, ge feorbuend 254b, ge feorbuend 254b, uncup es fela (ntr.) $876 \mathrm{~b}$. of course, a large number of these adjectives are not here used of persons, but most of them are so used. Surely it is remarkable that they are so numerous (85 in all, in Sheinert's 11st); and that not more than 10 can be considered physical in nature. It is to be remembered, too, that se goda is not, as in our translation, "the good one", vague as that being 1s; it is really "the good", a comple te anninilation of personality + the ending for gender, which is very formal, compared with out natural gender. $-0-$

* It should be saidhere that gold-hroden and hringedstefna quoted by Scheinert seem, aftex all, not to belong to the list. 
End- Nouns.

It will be observed that scheinert has included in his list of adjectives 7 participles or participial phrases: umborwesendum, searo-haebbendra, heardhicgenda, swidhicgende, blasd-agenda, dream healdende, and ge feorbuend. As one reads these, one recalls that there are other nouns of apparently participlal formation which, It would seem, should be mentioned. Of these Kärrehas made a study for his dissertation Nomina Agentis in Old English.* Professor Bloomsbur, reviewing this for t he Journal of English and Germanic Philology **, thus sums up Mre. Karre's conclusion:

"There evidently existed in Old English two strata of end- nouns: one old group inherited from primitive teutonic times and one group of new formations, made at different times during the Anglo-Saxon period. Even at the beginning of the old English period there existed some few end-nouns, in prose chiefly lawterms (agend, buend, teond, semend, wealdend), in poetry chiefly formations only used as the last elements of cpp. and early assuming the character of kennings (ealodrincende, heall sittende). The latter type was at once turned to extensive use, and a very large number of agential kennings in end, chiefly cp. words developed in $\mathrm{E}$ poetry. But in prose, too, especially in those texts translated from

*Upgala 1915

** V. 15,143 . 
the Latin a number of end nouns made their appearance The suffix became a frequently employed means for the formation of words designating the Deity, and also of words denoting the perforance of an action of a more abstract kind .... Yet it is a characteristic feature of almost all OE end nouns that they were never words for every day e (colloquial characters), but were exclusively literary words ... The end-nouns clearly bear the stamp of being occasional formations. The forms with adjectival endings belong especially to the poetic words alnost all compounds, and used in the plural 'e.g. salid epde sg. saelida); the genuine substantives used in prose rarely receive the adjectival inflection."

The following from Beowilf (rated by Kluge as old participles) are called nouns by Bosworth-Toller and are found in An̈glo Saxon prose. agend

Possessor, lord - God usually in Ags, poetry; wuldes agend Cri. 1198, An. 210; sigores agend Cri. 420; possibly; too, in B. 3075 . fold - b uend

Earth dwellers, terrestrials; cf. Cri. 868, Gu. I. 1014 . In Beowulf: hyne (dragon) fold buend swide ondraed 2a74; paet waes fore-maerost fold-buendum receda under roderum 309. 
landbuend

Native, inhabitants: ic paet land-buend

leode leode mine sele-raedende secgen hyrde

B. 1345; leoman to leohte land-buendum

wigend

Warriors - a much used word in poetry;

Wigend weord fullost wide geond eordan B 3599-

Beowlf; Gewiton him da wigend wica neosian

B 1125 - Hnaef's men; cf. also 1813, 3144

$3024,429,889,1972,2337$.

Very general words these.

The second group of end-nouns found in Beowulf

are found only in Ags. poetry and are thus only literary

words of a more adjectival nature. Ten of these occur only in Beowilf. They are alphabetted from the second element of the compound. bold-agend

one possessing a house: The word is used

in B 3112 of the castle-owing notables to whom Wiglaf appeals for aid (in 3111 haeleda monegum refers to the same).

folc-agend

One possessing people (i.e. having control

over ?) In B. 3113: hie bael wudu

feorran feredon folc-agende - Beowulf.

maegan-agend

One possessing power; in Beowulf only: 
lyt manna dah maegan-agendra 2837 - in a reflective passage.

helm-berend

One wearing a helmet. In Beowulf: he usic gar-wigend gode tealde, nwate helmberend 2642 (Wiglaf is rebuking his comrades); Gegrette da gumena gehwylone hwate helm-berend 2517. 
sawol-berend

One possessing a soul; in Beowulf only: gesecan sceal sawl-berendra......gearkve stowe 1004 .

god-fremmend

One who does good; in Beowulf only; godfremmendra sw.ylcum gife $p$ e bid paet $p$ one hilde-raes hal gediged--299.

guà-fremmend

One fighting, making war: ne ge leatneswora gud-fremmenara geariw e ne-wisson $B$. 246 .

bord-haebbende

$$
\begin{aligned}
& \text { Shield bearer:- paet eorl-werod...mod- } \\
& \text { giomor saet, bord-haebbende B. } 2895 \text { (only). }
\end{aligned}
$$

Iind-naebbende

$$
\begin{aligned}
& \text { Shieldbearer: No her cudlicor cuman on- } \\
& \text { gunnon lind-haebbende } 245 \text {--the coast } \\
& \text { guard is speaking of Beowulf's band; } \\
& \text { gumfeda stop lind-haebbendra } 1402 \text {. The } \\
& \text { word occurs only in Beowult. }
\end{aligned}
$$

rand-haebbend

$$
\text { One having or holaing a snield. In }
$$


Beowulf (only): naenig under swegles begarg rices iw yratra cand-niuvidenorid 681.

searo-haebbena

One wearing armor: hwaet syndon ge searo-haebbendra byrnum werede B.237.

hettend

Enemy, one hating: swa fec hetende hurt Ium dydon 1828; pone-de aer beheold wit hettendum hord ond rice 3004.

brim-lidend

Sea-sailing, sea-traversing, sailor (T. Iip to gol syap an na ymb brontne ford brim-lidende lade ne letton B. 568 .

heado-liđend

Sailor (T. derives the first part of the compound from hap, to fight. A warrior who sails the sea?) In Beowulf: sw ylce $P \mathrm{y}$ dogore heado-lidende habban scoldon 1798; ing55 the term is used ot Hygelac and hisband. 
mere-lidend

Sea-traversing, sailor: ne ge feor-buena mere-lidende B. 255.

sae-lidend

Sea-traversing, sailor. In Beowulf: saegdon paet sae-lidende 377--a general report, similarly 411, 2806; nu we saelidenà secgan wyllad, tiorran cumene 1818.

waeg-lidend

Wave-traversing, sailor: se (beorh) wals heah ond brad, waeg-lidendum wde gesyne B. 3158 .

sele-raedena

One governing (T. red to advise) or possessing a hall; in Beowult only: fien ne-cunnon secgan to sope seleraedende haeled under heofenum hwa $p$ aem hlaeste onfeng bl; Ic paet land-buend, leode mine sele-raedenảe secgan hyrde 1346.

ridend

Horseman; ridend swefad haeled in hodman B. 2457 (only)--no definite person is referred to. 
sceotend

Thrower, shooter, archer. In Beowulf:

sceotend swaefon 703--B.'s band; sceotend

Scyldinga to scypon feredon 1154--after

the overthrow of Finn.

heal-sittende

Those sitting in the the hall. In Beowulf

only: ne geseah ic widan feoch under heofones hwealf, heall-sittendra meduaream maran 2015; heal-sittendum 2868-Beowulf's men ( pegnum 2869)

Jmb-sittena

Neighbor: pec ymb-sittend egesan pywad B. 1827; him aeghwylc para jmbsittenara ofer hronrade hyran scolde B. 9; se folccyning ymb-sittendra 2734

weriend

Defender, protector, used in speaking of the Egyptians Exod.588. In Beowulf: wergenara to lyt prong ymb peoden 2882 .

gar-wigend

One fighting with a spear. In Beowulf (only): he usic gar-wigend gode tealde 2641 . 
The resemblance to participles and the adjectival inflection of these terms makes them especially vague, in my opinion. The verbal idea is surely uppermost, with few limiting lines set. waegen-agend, godfremmend, sawol-berend leave us groping for the vision of them because might and goodness and mortality are broad abstract ideas; but all the other terms, as well as these just mentioned, after all, fail to raise images in our minds chiefly because they abstract and present some one large simple aspect of a concrete, which is difficult to grasp just in porportion as it is large and simple. We visualize complex wholes and reflect about single features afterward. The words listed above give few more defining lines to the mental image than one adjective does, and hence we do not get concreteness of effect. Since they are poetic inventions, many occurring in Beowulf alone, the Anglo-Saxon audience could have filled in the picture little from edinary association. 


\section{Names of Leaders.}

bealdor

Chief, princeps (T. bel, to be strong), hero; the word occurs only in petry. In Beowulf: stid mod gestod wid steapne rand, winia bealdor (Beowulf) 2567; Sinca baldor, freawine folca 2428 - Hredel . brego

Chief (T. breh, to light up suddenly, to move quickly; ON bragr, the most noble one); B.T. says that the word is used chiefly by poets:- Used of God or Christ lengla, mancjnnes, heah-engla, gumena, - bregol cf. An 540, Gen. 1289, 191, etc. In Beowulf: brego beorht-Dena 427 - spoken of Hrodgar by Beownlf; His called eodor Scyldinga 428, wigendra hleo 429, freowine folca 430; brego Beorht-Dena 609 - again of $\mathrm{H}$. , who is called sinces brytta in 607; 3. haeled a brego - Offa 1. 1954 ( 0 . is not called a king, but the details given here suggest that he was); a difference of opinion exists about 1. 1925, but Hygelac is meant.

cyning

Chadwick' considers it probable that "the word cyning was once equivalent to cyneborn mon and applied to all members of the royal family. It is in form a patrongmic and perhaps originally meant "son of

\footnotetext{
'Origin of ENg. Nation Ch. 12, p. 315.
} 
the family". Later, he says ${ }^{I}$, "Perhaps the simplest definition is that he was a member of a royal family invested with some degree of authority, while the claim to royalty on the part of the family was derived from time beyond record and based, at least in England and the North, on divine descent."

In Beowrif, used:

1.) Of Sceaf 1.11

2.) Of Hrodgar 863, 920, 1010, 1306, 1890, 1885 , $2110,2191,619,867$.

3.) Of Beowulf, all after his coming into Hyoelac's place upon the death of his son - 2209, 2390 (?), 2417, 2702, 3171, 2912, 3121, 3093.

4.) Of Hyelac 1925, 2356, 1210

5.) of Fin 1153

6.) Of Heorogar 2158

7. Of Onela 2396

8. Of Hredel 2430

9.) Of Ongendrow 2950. In all 26 instances. In 1851, there is mention of choosing a king.

1. Origin of the Eng. Nation p. 315 
Here note in the references to Hrodgar as king that in 863 (see 2 above) he is god eyning, but in 862 he is wine-arihten, a name given to Beowulf before the death of Higelac and his son; in 1306 Hrodgar is frod oyning and in 1307 har hilderine; in 1870 oyning aebelum god is followed by pooden Soyldinga; rum heart cynxing 2110 against gomel gudwiga 2112 (Here be it noted that the king is not a warriod); sigrof cyning 619 stands over against edelwearde 6160 Similarly of Beowulf: in 2417 he is designated by nid-heard eyning, 2418 hallo, 2419 gold-wine Geata, 2421 done gomelan, 2424 gedelinged; in 2702 Beowulf is cyning, in 2709 peodne, 2722 wine-dryhten, 2733 se fole-cyning.

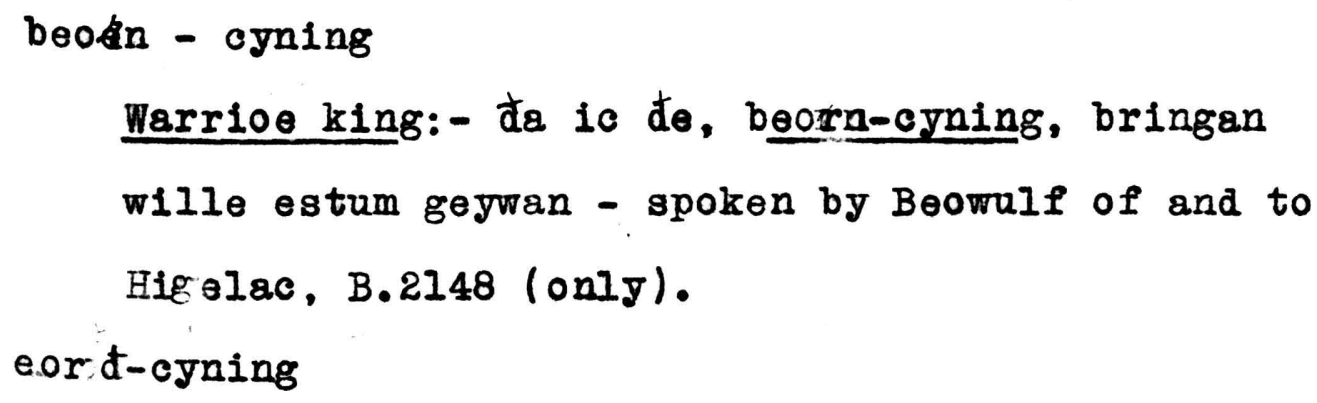

King of the people:- naes se folc-cyning gmb $(\theta)$ sittendra.... pe mec gud - winium gretan dorste; nealles folc-cyning fyed-gesteallan gylpan porfte 
2873-Beowulf.

heah-cyning

Most exalted king:- Christ, the king of Heaven, in the religious poemoe.g. . 628, Cri. 1340, An.6, Gen. 124; only once does it mean a man, B. 1039: paet waed hilde-setl heah-cyninges.

gud-cyning

Pighting or warlike king; only in poetry:- of Hrodgar B.199; of Hiqelac 1969 - he is spoken of as bonan Ongendea:es: 1968 and as hringas daelan 1970; of Beowalf 2335, when he is preparing to fight the dragon; also of him in the fight $2677,3036,2563$, however, whereas he is gud-cyning 2563, he is winia bealdor 2567 .

leod-cyning

King of the people:- Beowulf Scyldinga leof leod-cyning B.54 (only).

see - oyning

Maritine king:- helm Scylfinga pone selestan saecyninga - Onela, B. 2382 (only).

teod-cyning

King of people; said by $B$. T. to be used of an independent sovereign. In Beowrlf: Ongendeo 2963, 2970, Beowrif 3008, 3086, 2694, 2579; Hrodgar 2144. 
dryhten (drihten)

(T, drug, to work, perfowm druhti, following). According to Chadwick, "an old word which hlaford displaced. It is used to designate not only personal lordship, but also (in early poetry) the relationship of a king to his people." Later he says "It would appear that eyning was originally not a title of authority but rather equivalent to the modern word 'prince'. The title of authority was in all probability - hlaford or (in earlier times) dryhten". 2

Förster (Anglia Beiblatt p.167) says "00. dryhten ist nicht einfach 'kriegsherr, herr', sondern besser allgemeiner, und doch pregnanter, gefolgsherr."

In Beownlf: 1. worldly lord, 1484, 2560, 2991, 2402, 2901, 2338, 2789, eoela-- 2338, 2753, 2483, 1831; 2. More frequently used in poetry of God or Christ, B.686, 696, 187, 1554, 181, 441, 1692, 1779, 2330, 2796, 1398. These are Grein's citations. Instances of use in Beo. not cited by Grein:

Meaning worldly lord-2000, 2576, 1050, 2186 Meaning God-108, 1554, 1841, 940.

1. Studies in Ags. Institutions Ch.4, p.131 note. 2. 
Used 7 times of Beowulf, all after he is called king of the Geats, 5 times of Hygelac, 1 of Hrodgar, 1 of Hae tcyn.

frea-dryhten

Lord:-B.796, referring to Beowulf, who was not then king (deoden substituted 797).

freodryhten

Lord well -, or free-born; only in poetry. In Beowulf: 1. 1169 - spoken by Wealhdeo in addressing Hrodgar; 1. 2627, of Beowulf in his last fight. gum-aryhten

Iord of men; only in B. 1642:- gum-dryhten mid, modig on gemonge meodo - wangas tra - spoken of Beownlf who is called ealdor degna 1644, daedcene man 1645, and haele hilde-deor 1646. He was not then king.

mann-dryhten

Chief, lord; only in poetry:- syddan man-dryhten I. . holdne gegrette B.1978 - Hygelac; Beowulf calls Hygelac min man-aryhten 436; swa hira man - dryhtne pearf gesaelde 1249 - Beo, before the fight with Grendel; her si aeghwylc eorl odrum getrywe, modes milde man -drihtne hold - Hrodgar. Referring to Beowulf, after he has been made king, 2647 , 2849; referring to God 2865; to some unknown 
2281, who is also called hlaford.

sigedryhten

Lord of victory or victorious lord; only in poetry:Eow het secgan sigedrihten min aldor East - Dena, 391 referring to Hrodgar, spoken by wulfgar.

winedryhten

Friendly lord; only in poetry:- hie hur wine - drihten wiht ne-logan I glaedne Hrođ-gar B.862; Hrodgar again 360; wiston and ne-wendon paet hie heore wine-drihten selfne gesawon 1604 - Beowulf who has descended to the haunted mere; Beowulf again 2722, swa hit gedefe bid paet mon his wine -aryhten wordum herge 3175.ealdor

Elder, hence chief of the family, prince; means the chief butler Gen.409; is used in prose too:paet unriht poet his ealdras aer gefremedon (the iniquity of his fathers) Ps.108.

Beowalf 1. 1644 refers to the hero B.; 1848 to Hrodgar. 2920 to Hygelac; 56 to Scyld; 369 to B.; 392 to Hrodgar; likewise 568, 346, 592.

fengel (T. figh, to make fast)

Chief, lord; in Beowulf only:- Wisa fengel 1400 Hrodgar; likewise 1475 thus Gedenc un se maera maga Healfdenes snottra fengel; of also 2156; hringe fengel 2345 (Beo).- No indication of a special meaning in the word. 
folc-toga

Leader of people, chief ( $T$. tuh, to draw; ags. tiegan to bind); used only in poetry:- ferdon folctogan feorran and mena geond wid wegas wundor sceawian B. 839 .

frea

Lord - Chadw1ck* sayø, "The names Frey(e) and Freyia seem ariginally to have been titles 'lord' and'lady' respectively. The name (Freyle is perhapg an abbreviation of Yngvi-frey(e)...... But these may also have been titles of Swedish kings, for they are clearly related in some way to frea Ingwina, the titile borne by the king of the Danes in Beowulf."

In Beowulf:- In 1. 2285 it is not clear just who is meant, the same person is mandryhytne in 2281; used of God 1.8 7 and 2794 (wuldur-oyning, ecum dryhtne 2795-6); of Hrodgar (frea Scyldinga, Dena) 359, 500, 1166, 1680, 271, 291, 351, 1319; of Beowulf in his last fight 2853 (mandryhtnes 2849), 2662 (peodnes 2656), 3002 ( peod-cyning 3008, herewisa 3021) 3007 (haele hildedeor 3111), 2537. The word mean husband 1. 641:- eode to hire freacittan.

sin-frea

Everlasting lord, wedded husband (sen, old): faet dorste deor genep an swaesrá gesida nefne sin- 
frea B. 1934 (only)

hildf ruma

War*like chief (T. frufa, first); only in poetry:used of imperatorMaximianus Jul, 7 of Constantine in E1. 10 and 101. In Beowulf: Ba waes Gyldenhilt gamelum rince harum hildfruman on hand gyfen 1678 - of Hrodgar; wutun gongan to hedpan hildfruman 2649 - of Beowulf; similarly 3835.

land-fruma

Prince of the land; Beowulf only:- wine Scyldinga, leof land-frumä B. 31 - Scyld.

leod-fruma

Chief:- paet waes Hrodgare hreowa tornost fare pe leod-fruman lang begeate B. 2130 ( peoden 2131); (leod-fruma instead of land-fruma in 31, according to Libke). The word is found only in poetry •

ord-fruma

(T. usda, point place).

1. Author, creator: in religious poems.

2. Supreme one, chief:- waes min faeder folcum gecyded addele ord-fruma Esgdeow haten B. 263. wig-f ruma

War-lord; only in Beowulf. - wolde wig-fruma Wealhdec secan 664 - Hrodgar; ne maeg byrnan hring aefter wig-fruman wide feran 2261. hlaford

Lord; as indicated under dryhten, ohadwick consiers 
thisalater term, displacing dryhten; it is used of God or Christ as well as worldly lord: dryhten eallra engla and elda El. 475; of. also By. 135. In Beowulf: noldyber feasdeafte findan meahtan ..... paet he Heardrede hlaford waere 2375; Wiglaf uses the word in speaking of $B$. in 2642 ; used of Hrodgar 267; an unnamed lord 2282 (Hall translates it 'overlord'); used of Beowulf 3142 (maerne peoden 3141); similarly 3179 (wyruld, oyning 3180) 2634 .

leod

Chief, prince (poetical word):- wlanc Wedera leod B. 341; Weder geata leod 2551 - Beowulf. It is to be noted here that $B$. was not a king in 1. 625, but he was in 2551, and still we have the word leod. ff. also B. 669, 829, 1432, 1492, $1538,1612,2159,2551,2603,1653$.

raeswa

Forseer, provider, manager, prefect, chief Icel. raesir chief, captain, king); B.T. says thig word is used only in poetry, that it means a counsellor, one who takes thought for the public good - a ki ng. Citations: đoola raeswan (God) An. 1624, folces raeswan An. 619. In Beowulf: in worold wocun weorda raeswa ( $n$ ) Heorogor and Hrodgarond Halga til B. 60 .

dengel

Chief, lord:- Baer pa seobrim-wyl(f) .... hringa 
pengel B. 1508 (Beowulf in flght with Grendel's mother); manna pengel Exod. 173 - God? called segn-cyning 172. Only in poetry.

deoden

1. Worldy lord; so used 39 times in Beowulf, also in Exod. onee fud. (3 times) EI. (onee) An. (3) By. (4)

2. Of God and Christ - cormon in An., El., and Gen. (14 times in this last; not in Boowulf Chadwick* says "These are words peodon and dryhten are clearly derived from peod and dryht, and neither of them contains any notion of hereditary qualifications.

In Beorulf:

In 1. 129 it is used of Hrodgar (In the same place he is aedeling aergod); 1.2338 indefinite, altho spoken of Beo., who is then king; peoden min 365 (Wulfgar addresses Hrodgar); peoden Hrodgar 417; maere peoden 1715 -- Heremod; gud-cyning Wedera peoden 2336 (Beowulf);

* Origin of the Eng. Nation ch. 12, p. 316. 
Hredric . . peodnes bearn 183\%; (Heremod) " " 910;

Wealhdeo "dohtor 2174;

Swa hit . . diope benemdon deodnas maere so70; used of Hrodgar 1046, 1871, 2131, 301, 345, 1992; of Beowulf (before he is king) 1598, 797, 1525, 1627; (after h由 is king) 3860, 2810, 2721, 2786, 2883, 3079, 3141, 2788, 2656, 2572, 2709; of Higelac 1211 (on the Frisian expedition); Scyld 34; deoden Heado-beardna 2032; Onela 2384; Hnaef 1085; doubtful 2219.- The word is used 5 times in address. 
2. Descriptive Terms Denoting a Chief.

brytta

Digpenser, giver ( $T$. brut to break); the word is found only in poetry. In Beowulf:- a term applied to Hrodgar 607 (brego Beorht-Dena 608); Hrodgar again 1170 (so addressed by Wealhdeo, who also calls him freo-dryhten); Higelac 2071, 1922; beaga brytta 1.35 - Scyld;

" 352 - Hrodgar; similarly 1489.

eodor

1. Enclogure (Tedura fence, hedge). In Beowult heht mearas on flet teon in under eoderas 1037 (only instance in Ags. Iiterature.)

2. Chief, protector. In Beomilf: eodor scyldinga 428, 663; eodor Ingwina 1044 . The word occurs only in poetry.

frumgat

Leader, chief, more precisely first spear; a word appearing only in poetry: cf. Jul 685 ( Satan ). In Beowulf: ne meahte he on eordan ..... on dam frum-gare feorh gehealdan 2856 - spoken of Beowulf who lay dead.

gebyrga -- occuring only in the compound leod-gebyrga. leod-gebyrga

Drotector of the people ( $T$. berg to hide); only in poetry:- Beowulf speaks of Hrodgar as leod-gebyrga in 269 . (He called him hlaford 267). 
gifa, giver, occurring in Beomilf only in compounds. Beag-gilfa

Giver of ringe; the word is a favorite in poetry. Beowilf: đeah hie hira beag-gyfan banan folgedon 1102 - Hnaef: "Though they were following the slayer of the man who had given them rings, had treated them generouslyn. The shame of it! gold-giefa

Giver of gold. In Beowulf: me is micle leofre paet minne lic-hama mid minne gold-gyfan gled faedmie 2652 - of Beowulf.

sincglefa

Give: of jewels; a poetic word:- meaning Christ in Cri. 460. In Beowulf:- hyra sincgifan 2311

- Beowilf; ne gercaegen ic pa maegde maran worode ymb hira sincgyfan 1012 - Hrodgar; se-de sefter sinc-gyfan on sefan greoted 1342 Hrodgar? Aeschere? Usually used of king's. wilgiefa

Joy giver, king (in poetry, alone):* weorada willEiefa El. 816 - In Beomulf: nu is wil-geofa Wedera leoda, dryhten Geata, dead-bedde faest B. 2900.

helm

Gr. says the word means first 'protector', then "helmet"; it is not then a metaphor. Meaning protector and then king it is found only in poetry; (aectelinga, haligra, haeleđa, duguda, dryht-folca, engla, gasta, heofena, wuldres,-helm). In Beowulf: Hrodgar .... helm Scylding B. 456, 371, 1321); 
cf. also no heo on helm losap, ne on foldan fae $p$ m 1392.

hierde (hyrde)

Protector, custodian, lord, shepherd:- used of God in Dan. 11, Gm. 761, Gen. 2315, 164, Dan. 199, etc. In Beowilf: Ofoloh da aet paere saecee fa me sael ageald huses hurdas B. 1666; of Hrodgar - byrde folces 610, rices hyrde 2029; of Higelac-folces hyrde 1832, 1849; of Beowulf 2644 and 3080; Grendel,-fyrena hyrde 750; of the dragon, beorges hyrde 2304; fraetwa hyrde 3133; Daeghrefn 2505; Onqend eo 2981; some unknown chlef 2245; some monster sigmund killed 887; God, wuldres hyrde 931; consclence? - Sawele hyrde :742.

hleo

Protection covering ( $T$ to be warm), protector:Beorna hleo ece aelmihtig Jul. 272. In Beowulf: wigendra hleo, eorla hleo etc. -

Hrodgar 429, 1035, 1866, 2142, 2190 (heado rof cyning 2191); Beowulf 791, 2337; Sigmund 899; Higelac 1967, 1972.

munabora

Protector ( $T$ mundo hand, and ber, to bear, car ry) According to chadwick * the mund represented a mants guardianship over his followers, and the guardian was entitled to recompense for any violation of his "mund". In Beorvilf:- wes dh mund-bora minum 
mago-degnum, hond-geselz um B. 1480. B. is asking Hrodgar's protection for his men; dara madna mund-bora waes 2799 - referring to the dragon.

strengel

Leader, one who strengthens and emboldens:-

B. 3115 only - wigena strengel; perhaps, too, 1 . 1548 - wigena strengel (or strengest?)

wine

Friend, especially beloved lord or hugband:most often found inpoetry. In Beowulf: wine Scyldinga B. 30 - Hrodgar (leof land-fruma 31); similarly 148, 1183, 2101, 350, 2026, 170; wine min Beomilf 457, 1704; Unferth 530; winigea leasum 1664; bealdor winia 2567; winium Scyldinga 1418 - Hrodgar's men; Cf. also 3096, 376, 2047. freo-wine

Noble friend, or friendly chief; in Beowilf only:1. 430 of Hrodgar, who is calied brego 427. frea-wine

Dear lord,; in Beowilf only:- frea-wine folcas (folca) 2357, 2429; his (Haedcyn's) frea-wine (Herebeald) 2438. -

gold-wine

Friend who gives gold, king; a word found only in poetry. In Beowulf, gold-wine gumena 1171 - Hrodgar (einces brytta 1170); similarly 1476, 1602; of Beowulf, 2419,2584 .

gud-wine

Ally in War; in Beowulf only: he done gup-wine 
godne tealde 1810 - the sword; similarly, 2735. maegwine, s. Nouns indication kinship. wisa

Leader ( $T$. Vit to know). In Beowilf:- werodes wisa word-hord onleac 259 .

brim-wisa

Leader through the waves of the sea. In Beowulf only; abreot brim-wisam (Haedcyn) 2930.

here-wisa

Leader of the army. In Beowulf nu se here-wisa hleahtor alegde 3020 - Beowulf.

hildewisa

War leader. In Beowulf: fore Healfdenes hilaewisan 1064 (only). All four (wisa and ita compoundsl are terms of poetry only.

Noteworthy points:-

1.. There is a very general interchange of terms here. More of that later.

2. Wore $t$ an half of these terms are purely, poetic. Only 19 out of 53 ever occur in prose, and four of those 19 are recognized as more common in poetry.

3. The use of compounds tends to increase the vague descriptive effect. What is the difference between cyning and folc-cyning, or leod*cyning or feod cyning? For that matter, what is the difference so far as use shows, between eord-cyning and sae-cyning? 
4. The fact that the poet almost never uses one term without strengthening it, in the next Iine or half line, with another of almost the same meaning for the tranglator, would naturally lead to the conoluoion that these words had some special idea value, some quality coloring for him. But Group 1. will not bear out this 1dea. It is fairly clear what is meant by cyning, but in the rest neither the root meaning nor the exact limitation of the word appears. To be sure, ten of these terms - bealdor, brego, cyning (the compounds of cying have not been counted here), dryhten, freodryhten sigedryhten, hildgruma, landfruma, leodfrumma, hlaford are used only of kings; but one doubts whether it may not be therefore prope rly assumed that these terms may not be used of leaders who are not kings. For instance, ereadryhten, gum-dryhten, mann-dryhten, wine-dryhten are used of Beowulf wien he is merely the commander of a band of fifteen, whereas dryhten, freodryhten and sigedryhten name only kings. The difference in use was simply fortuitous, one fees. At any rate, why ten terms for king ?

5. There are 6 pleonistic compounds among these names for leaders and 4 compounds which serve to pay a graceful little compliment, e.g• sigedryhten, heah-cyning.

6. The second group does not merely name the king, it tells someting about the king, offers comment on his power, or his attitude toward his people. Beag- 
gifa and gold-gifa give opportunity for vigualizing sinc-oifa is a bit more vague and brytta still more. However, these words are concrete additions; wine and wiga show again the "innerlichkeit" of the poem. 
3. Names for Common lien: Terms of Very General Meaning.

ceor 1

Wan, hero (T. ker to become mature). In Beowulf: ealdam ceorle 2972; gomelum ceorle 2444; snotere ceorle 202, 4I6; smoter ceorl monig 908 (referring to the people of Heremond, who lament his evil ways); cf. 1591, where Ongendeow is meant - a king, not a common man. Cha divick has this to say of the crorl: The crorl was an or dinary freeman (1); the corl class from the loth century included all free ersons of tnglish blood. The distinction between thegn and crorl is from the time of Aethelstan (925) the broad line of demarcation between classes of society 773. But he is describing the ceorl of a later time; as we have seen, a king could be called a ceorl in Beowulf.

firas

Men, homines (T. ferhva, body life; Ig. rt. perk; fehrvia, living being):- fira cynn An. 590, rl. 898. In Beowulf:- frumsceaft fira B. 91; moneoum fira 2001; fyrngeweorc fira 2886; waldend fira 2741; 2250 doubtful.

guma

Homo, man ( Ig. ghzm, ghzom (?), earth; the word

CHADWICK; Studies in Ags. Institutions p. 161. 
occurs in Beowulf 34 times:- Swa sceal geong guma gode gewyrcean 20; feasceaft guma (Grendel) 973; also in 1682; swa guman gefrungon 666; very indefinite 878; metod eallum weold gumena cynnes 1058; spoken of Hrodgar and Beowulf 65:; of king's pegn 868; Beowulf is called guma gudum cup 2178 and bearn agdeowes 2177; used by Beowulf in adaressing Hrodgar 1384; gutsearo gumena 328.

driht-guma

Wan of the people, noble, man (a. druhti, troop, following); the word appears onld in Beowulf:-dec, dryht-guma, dead ferswyded 1768 -- spoken by H. to B.jpaet bid drihtguman unlifigendum aefter selest 5388 (in a bit of general moralizing); Swa đa ariht-guman areamum lifon 99 (in an account of early joy after the creation.). used as parallel to pegna in 12.1; niht helm ge-swearc deorc ofer dryht-gumum 1790 .

Considering its origin, one should translate 'the word man of a troop', but neither Gr. nor B. so translate it. For does its use seem to call for such a translation.

haelet

Man, hero, human being ( $T$. haled man hero; $0 . N$.

(2) Studies in Ags. Institutions p. 86 :

(3) " " " p. $7 \%$. 
halr man. Of uncertain etymologyl:-- haeleda cyn (human Find) An. 545, 567, 909, 11. 188, 1204; haeleda wealdena (cyning etc.) God, Christ. An. 396, 1465, 3. 852. In Beowulf:-- haele hilde-deor (Hrođgar? or Beowulf?) 1815; ne minte snotor haeled wean onwendan 191; wlonc haeled 331 -- spoken of Frodgar's ar ond ombiht (336); men ne-cunn on . . . haeled under heofenum hwa faem hlaeste onfeng 52; Heold pu nu, hruse, nu haelet ne-moston 2847; ridend swefad, haeled in hodman 2458 (in a bit of general reflection); hordburgh haelepa 467; haelepa hleahtor 6Il; haelepa rice edel scyldinga 912; Hredric ond Hrotmund ond haelepa bearn 1189; pegn nathwylces haeleda bearna 22:4; spoken of nnaef 1069; Hrodgar's haelepa gedryht 662; a very general term in all other cases of its use $(1047,1198,1296,1830,1852,1954,2052$, $497,2072,3005,3056,3111,1709,1961,2024,22621$. Used 29 times in Beowulf. It is a work found only in poetry.

ielde

Homines, human beings, men ( $T$. al to nourish); it is a poetical term. In Beowulf:-- ylda bearnum 150; ylda waldend 1661; Him on fyrste gelomp aedre mid yldum 77; cf. also 605, 705, 2117, 2214, 2514, 2611, 3168. (10 times in the poem). 
man

Vir, homo, man (1. men to think?). The worth appears 78 times in Beowulf:

waepned-man

Nasculine being, man; used, in prose, of the male plant once. In Beowulf: swa bid maegpa craeft wig-gryre wifes be waepnedmen 1284 .

rinc

Man. B. . cites Icel rekkr and says that rinc is a poetical term. In Beowulf: $\mathrm{ymb}$ hine rinc manig prydlic pegna heap 399; referring to Grendel 720 ; to Efor 2985; slaepenane rinc 741 -- Hondscio; hnahran rince saemran aet saecce 952; gamelum rince 1677 -- Hrodgar: cf. also 747 .

magu-rinc

lian (foung only in poetry).

swefan sibbe-gedryht samod aetgaedere mago-rinca heap 730 -- Beowulf's band.

The other compounds with rinc are found under other headings.

scealc

Servant, minister, man; the word certainly has the notion of servant in its root, but man best translates it in Beowulf:-- Eode scealc monig. swid- 
hicgende to sele dam hean 918 -- the men who came to the hall to see Grendel's arm; nu scealc hafad purh drihtne mint daed gefremede 989 -- Beowulf; Beorscealca sum fus and faege flet-raeste gebeag 1240. B. Th. translates this last as 'beer-server', 'butler'. One wonders how that can be when the line is foretelling the doom of Aeschere, high favorite with Hrodgar, his runwita and raedbora. The word, however, is a term of reproach in By. 18I, and means the ship's crew in Wal. 31. Hence, perhaps, we must concluae that the general sense 'man' is confined to Beowulf.

$\sec g$

Man (T. Sehv to follow; sag(v)ja, attendant); a word used only in poetry. In Beowulf:-- secg wisade, lagu-craeftig mon 208; secg on searwum 249 (called seld-guma in the same line); secg weorce gefeh 1569 -- Beowulf; paet waes modig secg 1912; sigor-eadig secg B. 2362; se secg waere synnum scildig se done wong strude 3071; secga gedriht 633; Beowulf -secga betsta 947 , 1759. Very loose in use -Wulfgar, Hunferth, Beowulf, Wiglaf, Hrodgar's men, Scyld's, Beowulf's. It is not in any place used of a king, however. 
đegn

Servant, man, warrior, knight. B. T. offers the following list of meanings: 1) a servant, 2) an officer, or minister; 3) a soldier, 4) a disciple (Johannes, se deora pegn Blickl Hom. 67, 22); 5) one engaged in the king's service; 6) in poetry, a complimentary term for man or warrior.

From Chadwick * we learn that before the time of Aethelstan (925) the word pegn occurs in the laws only in the expression syninges pegn. Latin equivalents are minister and miles. Pegn is used for servant both in the early and late texts. $0 . \mathbb{N}$. pegn liegeman. "The sense of subordination was inherent in the word from very early times. The sense of rank must originally have been due to the dignity of the person to whom the fegn was subordinate."

In Beowulf:-- pegn nytte beheola se-đepn handa baer hroden ealo-waege 4949; cyninges pegn . • gidala gemyndig 868; se faemnan peng 2059; pegn nathwolces haeleda bearna 2223 (Clark Hall translates degn here 'slave'); swylce sceolde secg wesan pegn aet dearfe 2709; (called sib-aedelingas 2708); ealle beweotode pegnes pearfe 1797-- Beowulf; (Grendel)

* Studies in Ags. Institutions p. 85. 
genam pritig pena 125; Ic de pusenda pegna bringe haelepa ta helpe 1829; pegna gehwam para leoda 2033; ea.loor đegna 1644; đegna betstan 1971 -- Beowulf; Beowulf, Higelaces đegn: 194, 1574;

Beowulf's men:3121, 1627, 2869;

Hrodgar's men: 1341, 1419, 400, 1673;

Hengest, peodnes degne 1085;

Wiglaf: 2721, 2810;

Eofor: 2977;

Finnes pegnas: 1081;

Coast guard: 235;

pegnas syn(don) ge waere peod eal-gearo 1230 -Wealhdeo is speaking of the men in Hrodgar's hall (She speaks of aegnurido eorl 1228).

ealdor-pegn

Chief minister, chief (elder pegn?): found only in poetry:-- sydfan he aldor-pegn unlifigendne pone deorestan deadne wisse 1308 -- refers to Aeschere, high favorite with Hrodgar. This same word is used in speaking of Satan, Sat. 66 .

heal-đegn

Vir qui in aula versatur: a man who dwells in a hall; in Beowulf only:-- heal-degnes hete 142 - or hellđegnes? naefre he on aldor-aggum aer ne sipdan 
hearäran haele heal-đegnas fand: 719.

A suggestion here that not all men dwelt in a hall?

magopegn

Servant, man, vassal. In Beowulf: ic eom Higelaces maeg and magopegn 408; magupegnas mine 293; magopegna pone selestan 1405 -- Aeschere; mago-pegn modig 2757 -- Wiglaf; cf. also 2079, 1480.

ombiht and sele-degn appear easewhere.

wer

Latin vir, man; used 16 times in Beowulf. wonsaeli wer 105 -- Grendel; similarly 1351; wonsceaft wera(s) 120 -- mortals(?); Beowulf and his men 216 (guman 215, secgas 213); men in Hrodgar's hall 1233 (pegns 1230, peod 1230, dryhtguman 1231; eorlas 1235 seems to refer to the same people); wera and wifa 993; cf. also 1650, 1731, 3003, 2947, 1256, 1222,1440 . 


\section{Nouns heaning Warrior}

beom

Strong man, soldier, man (this word is used only by the poets); the last meaning man is really the first one, according to B. T. In Beowulf: maere mađdum-sweord manige gesawon beforan beorn beran 1024; blaed-faestne beorn 1299--Aeschere (he is called haeleda leofest 1896, rice ranäwiga 1298, runwita, raedbora 1325); naes ic him to life ladra owihte beorn in burgum 2433--translated by Clark Hall 'page'; Biorn under beorge $2559--$ Beowulf; seo herepad . . brosnad aefter beorne 2260; cf. also 2220 and 2404, where the word is very general in meaning. guđ-beorn

Warlike man; only in Beowulf:-gud-beorna sum wicg gewende, word aefter cwaed 314 (spoken of the coast-guard).

cernpa

Warrior [Ety:-Germ. kampf, Latin campus. Is it built out of the Latin word? Kluge seems to suggest that origin for Kampf (Etymol. WOrterbuch der deutschen Sprache)]. The word is used as a name given to christ in Gen. 530. In Beowulf: ae pele cempa 
self mid gesid um 1312; he him daeslean forgeald repe cempa 1584-- of Beowulf in the Grendel fight; he fyrmest laeg, gyrded cempa 2078--Hondscio, just before his death; Haefde da forsidod sunu Ecg peowes under gynne grund Geata cempa 1551; onginned geomormod geong(um) Eempan purh hredra gehygd higes cunnian wigbealu weccean 2044--of Ingeld?); 7 a waes forma sid geongum cempan 2626,--ci. also 2b02, $1761,1948$.

fepa and fedecempa Foot-soldier, infantry; the word fede-cempa appears only in Beowulf:--oferwearp pa werig-mod wigena strengest fepe-cempa 1544; He gewergad saet fede-cempa frean eaxlum neah 2853; naes him aenig dearf....odde in Swiorice secean $p$ urfe wyrsan wigfrecan weorde gecypan; symle ic him on fedan beforan wolde 2497 .

Apparently all warriors were footsoldiers. They dismounted upon arriving at the place of the fight.

freca

A wolf, also, a hero (Torp--freka fresh, en- 
ergetic, eager, bolä); a word found only in poetry. In Beowulf:--He gefeng $p$ a fetelhilt, freca Scyldinga 1563.

gud-freca

One bold in battle (only in poetry):- gearo gud-freca (aragon) gola mađmas heold 2414. Translated 'warrior' by B. T.

hild-freca

One bold in battle (in Beo. and An. only) In Beowulf:--ly 4 eft becwom from $p$ am hild-frecan hames niosan 2366; hearde hild-frecan-the Scildings 2205.

scield-freca

Fighter with a shield; in Beowulf only:ponne scyld-freca ongean gramum gangan scolde 1033.

sweord-freca Warrior with a sword:- pa he paes waepnes
onlah, selran sweord-frecan B. 1468 (only). wig-freca War hero, war-wulf(?):-naes him aenig dearf 
............ - secean purfe wyrsan wig-frecan. B. 2496; wyrsan wigfrecan naetre wael reafedon 1212. In Beowulf only.

Ierhd-frec

$$
\begin{aligned}
& \text { (adj) Full of life, animated, bold:-Swylce } \\
& \text { ferhd-frecan Finn eit begeat sweord-bealo } \\
& \text { sliden B.Il46 (only). }
\end{aligned}
$$

(oret-maecg

loretta

Combatant, champion, warrior; the second (oretta) is tound only in poetry. In Beowulf:- pone yldestan oret-mecgas Beowult nemnad 363 (they are callea heaporincum 370); gebeotedon . . oret mecgas paet hie in beorsele bidan woldon Grendles gu pe 481; wlonc haeled oretmecgas aefter ae $p$ elum fraegn 332 ; yore oretta 1532-Grendel; Aras da bi ronde rot oretta $2538--B e o w u l f$. Anareas:-used ot the disciples 664; eadig oretta (st. Andrew) 463.

rine--s. Group 3 . beado-rinc Warlike man; in Beowulf and Judith only. betst beado-rinca waes on bael gearu $B$. 


\section{9--Hnaref.}

gud-rinc

Warlike man; (a worá chiefly poetical.) In Beowalf:- ymb pa git-healle gud-rinc monig 838; gud-rinc gold-wlanc graes-moldan traed 1881--of Beowulf; Beowulf again 1501; wie manaryhten maegenes behofad godra gudrinca 2648; cf. also 1118 .

heado-rinc

Warlike man (T. had, to fight); a word found only in poetry. In Beowulf:- he pone headorinc hatian ne-meante 2466--referring to Haedcyn, who had slain his brother by mistake; se paem heado-rincum hider wisade 370--Beowulf's men.

here-rinc tharja, army)

Warrior (A word found only in poetry). Ne man saegde paet $p u$ de for sunu wolde hererine habban B. 1176. (The manuscript has hereric).

hilae-rinc Warlike man ( $\mathrm{T}$. hel, to beat). In Beowulf: 
Pa waes frod cyning har hilde-rinc 1307-Hrodgar; brim-wylm onfeng hilde-rince Beowulf) 1495; Beowulf 1. 3136, 1576; one of Beowlu''s band 3124; Grendel 986.

wiga

Warrior (T. vih, to fight). In Beowulf:He paet ful gedeah wael-reow wiga 629-Beowulf (called eorl 627); wigena strengest, fede-cempa 1544; wigena weord-mynd 1559 (speaking of a sword); wigena strengel 3115--Beowllf; ofer sae side sunu Otheres wigum ond waepum 2395.

aesc-wiga

(Ashen) spear-bearing warrior (in poetry only). In Beowulf:- eald aescwiga se de eall geman gar-cwealm gumena 2042; waeron a.eswigan, secgas ymb sigecwen sides gefysde El. 259.

by $-w i g a$

A fighter in armor (one wearing a bytre). Liss Keller* says that only nobles wore

*Ags. Weapon Names, Ax glistische Forschungen 14-17, p. 95. 
the by me. In Beowulf:- se by rn-wiga bugan sceolde 2918--Higelac. The word is found only in poetry.

gar-wiga

Fighter with a spear. In Beowulf:- byrne ne-meahte geongum garwigan gece gefremman B. 2674; pegne gesealde geongum gar-wigan 2811. (The word is not found outside of Beowulf.)

guđ-wiga

Warrior:- gomel gud-wiga giogude cwiđan B. 2112 (only)--spoken of Hrodgar.

lind-wiga

shield-bearing fighter:- leoflic lindwiga B. 2603 (only) -- wiglof.

randwiga

Warrior with a shield (found only in poetry.)

In Beowulf:- se waes Hropgare haelep, a

leofost on gesides had be saem twoonum, rice rand-wiga 1298--Beowulf who has just slain Grendel; rofne randwiga restan lyste 1793. 
scyla-wiga

Shield-bearing fighter:-scearp scyld-wiga gescad witen worda and worca B. $288--$ Hrodgar. Phe word is found only in poetry).

$\mathrm{He}$ is a man of arms, a man of war, a fighter of battles--proudly the narrator rehearses his tale. The hero is a shield-warrior, a spear-fighter, a sword-fighter, i.e., he is a fighter in good truth. He is no seldguma, no man who stays at home. The compounds of the foregoing list are not used to give concreteness. Wiglaf is gar-wiga although he fights with a sword. It is the valor, the bold spirit of the man which the poet would have his audience feel, and he contrives by the long roll of the kennings to secure the emotional response he desires. 


\section{Terms for Men Having an Occupation Other than Warfare.}

\section{Sailor, seaman}
a) lidman (a word appearing only in poetryl. com pa to lande lidmanna helm 1623-Beowulf.
b) merefara: waes him Beowulfes sid modges mere-faran micel aef-punca B. 502.
c) saeman:- garas stodon saemanna searo B. 329; paet he saemannum onsacan mihte heado-lidendum hord forstandan 2954.
d) saerinc (only in poetry)..- ond hine ymb monig snellic sae-rinc sele-raeste gebeah B. 690 .

Men on special guarà duty?

a) bat-weard, guardian of the ships:-He paem bat-wearde bunden golde swurd gesealde B1900.

b) hyd-weard, port guard:- Hra pe waes aet holme hyd-weard gean se $p$ e aer lange tid leofra manna fus aet farode feor wlatode B. 1914 (only).

c) Iand-weard, Guardian of the land:- landweard onfand eftsid eorla swa he aer dyde B. 1890 (only). 
d) sele-weard aseted B.667--a sentry.

e) endesaeta, coast guard:-- Ic hivile

Io waes ende-saeta aeg-wearde heold

B. 241 .

Not one of these words occurs outside of Beowulf.

\section{Counsellor}

a) raedbowa (T. red to advise, ber to bear): se waes min renwita and min raedbora (referring to Aeschere) B. 1325.

b) runwita (T $\underline{\text { ru }}$ to whisper; runo whispering, secret) In addition to its occurrence in Beowulf 1325, this word occurs in Gn. 1068, tmeaning"one acquainted with mysteries, a sage."

Messenger

ar:- Ic eom Hrođgares ar ond ombint B. 336; Ar waes on ofoste eft-sides georn 2783.

Entertainer

a) gleoman, singer:- Leod waes asungen, gleomannes gyd B. 1160 
b) scop, poet, singer:- Scop hivilum sang hador on Heorot B. 496; ef also 1066, 90.

c) łyle, orator; one who leads the conversation about the court (Heyne):- Swylce paer Unfer $p$ pyle aet fotum saet frean scyldinga B. 1165; cf also 1456.

Artificer

smid:--swa hine fyr-dagum worhte waepna smid B. 1452; searo-net seowed smipes or- pancum 406.

Servant, Menial?

a) feormynd; Grein translates the word as first meaning 'one who receives hospitality' (ct. Vy 30), then meaning polisher.' In Beowulf:feormyna swefad pa pe beadogriman bywan sceoldon 2256 .

b) lombint (ombint-đegn

Servant: Weard ma pelode daer on wicge saet ombeht unforht B. 287; cf. 336; sealde his hyrsted sweord irenna cyst ombint-pegne 673.

c) seledegn, hall attendant:- sona him sele-đegn siđes wergum feorran-cundum ford wisade B. 1794 (only). 
6. Terms Implying a Certain Nobility of Rank.

aedeling

Nobleman (used of God, Christ, king, man). Chadwick (1) says, "In Beowulf the word aedeling seems to have a somewhat indefinite meaning. It is applied not only to members of the royal family, including kings, but also to king's degns and prince's degns, whom we have no reason for believing to be of royal blood." (T. adala, kind, inner being). In Beowulf: Maere peoden aepeling aer-god unblide saet 130 -- Hrodgar; aepeling manig wundum awyrled 1112 -- degns of Huaef(?); Wes pendenfu lifige aepeling eadig 1225 (Wealhdeo thus speaks to Beowulf); of Beorulf 2342 after calling him gud-cyning 2335, and Wedera pioden 2336, wigendrahlee 2337, eorla dryhten 2338; Beowulf again 1815 and 3135; aepeling on elne 2506 (in an adjectival sense?); of Beowulf 2188, when the sons of the Geats and even the "drihten wereda" held a mean opinion of hirm; Beowulf again 2667, 2424, 1596, 2374; he is aepelingabearn (?) 1408; of Heoroweard 2443; Sceaf 33; Sigmund, aepelinges bearn 888; Hrodtar's men 982; Beowulf's men 1804, called scaton 1803;

(1) Ags. Institutions, Addenda p 416-17. 
they are aedelinga bearn 2597 (hand-gesteallan 2596); of men in the hall 118 and 1294; the twelve chieftains 3170;molear reference 1. 1244 and 1. 3; aepelinga gestreon 1920 .

sibb-aedeling

A man related, kinaman;- hi hyne pa begen abroten haefdon sib-aedelingas: swylc sceolde secg wesan pegn aet dearfe B. 2708 (only).

$20 \times 1$

Nobleman, courtier, man, human being (T. suggests that perhaps the word comes from the dg. rt. er, $\operatorname{man})$.

Chadwick (1) points out that the word does not occur before the time of Aethelred (978), except in poetry, and there only in the sense of 'noble'.

Förster (2) says, "Fur eorl passt die ursprüng\$iche bedeutung edelgeborener Mann, Mann des hoheren adels nicht mehr auf den kulturzustand der uns vorliegenden Beowulf redaktion; denn hier findet sich eorlas sowohl fur den geburts= wie fur den dienstadel gebraucht. Auch aedeling

(1) Studies in Ags. Institutions p. 162 and 163.

(2) Anglia Beiblatt 13, p. 166. 
erscheint im Beowulf meist bereits auf angehörige des herrschenden königsgeschlechtes beschrankt wenn daneben auch noch die ältere weniger exklusive bedeutung adeliger vorkommt, freilich gleichfalls vom geburtsadel auf dienstadel ubertragen".

In Beowulf:- Egsode eorl 1.6; her si aeghwylc eorl oprum getrywe 1228; swylc scolde eorl wesan, aepeling aer-god 1328; nalles eorl wegan mad dum to gemyndum 3015; Wundur hwar donne eorl ellenrof ende gefere 3063 ; oft sceal eorl monig anes willan wraec adreogan 3077; a similar general statement, in which eorl means little more than 'man', 'follower of a chief', 573, 627, 1757, 248, 369, 2448, 2891, 791; eorla hleo, $1035,1050,1866,1967,2142,2190,2338$; eorla gestreon 3166 .

Spoken of Beowulf in the dragon fight 761; in the fight with Grendel's mother 1512 (he is also called pengel 1507); paet des eorl waere geboren betera 1702; cf. also 982 .

of a noble in Beowulf's company 795; Wiglaf 2908, 2695; eorl Ongendeow 2951 (he is a king); followers of Beowulf or Hrođgar $689,35 \%, 431$, $1235,1238,1312,1420,1891,769,1281,1649$, 676, 2021,2816 . 


\section{Descriptive Nouns Denoting Men.}

bana (bona)

Slayer. In Beowli: fa ic on morgne gefraegn maeg oderne billes ecgum on bonan staelan 2485 ; dupinum brodrurn to banan wurde 587; hie hira beaggyan banan folgedon; bonan ongenpeoes 1968; para banena byre 2053. Bana will be included in another list where it applies to Grendel and his kind.

feorh-bana

Homicide. In Beowulf: winte ne-meahte on dam feoth-bonan faeghde gebetan 2465 -- Haedcyn. hand-bana

One who kills with the hand. In Beowulf: weard him to handbonan 460 ; of. also 1330,2502 . The word occurs only in Beowulf.

geselda

A tent companion, comrade. (T. salqz dwelling:). In Beowulf: Higelac ongan sinne geseldan in sele pam hean faegere fricgean 1984 -- Beomulf. geneat ally, vassal; only in compounds in Beowulf. beod-geneat

Table companion.. In Beowulf: we synd Higelaces 
beodgeneatas 343 ; beodgeneatas, eaxlgesteallan 1713. (In Beomulf only).

heord-geneat

House companion, sharer of the hearth. In Beowulf: We synt gumcynnes Geata leode ond Higelaces heord-geneatas 261; he Hrodgares heordgeneatas sloh on sweofote 1580; nealles drunone slog heord-geneatas 2180; in 3178 the word is used as parallel with Geata leode 3178; in 2418 the word refers to Beowulf's band, whom he is addressing as they sit upon the headland.

geselda

A companion, comrade in hall. In Beowulf: Higelac ongan sinne geseldan in sele fam hean faegere fricgean 1984 -- Beowulf.

gesella s. hand-gesella hand-gesella

One who stands at one's hand, close at hand. In Beomlf: Wes pu mundbora minum mago-pegum, hordgesellum 1481.

gesid

Comrade. Chadwick (1) says that the "term was originally used of a man who was connectedith

"Studies in Ags. Institutions p. 375. 
another man by a personal bond." Later it denoted a man with some kind of authority over others. The word is found in prose.

In Beowulf:- haelepa leofost on gesid-es had 1297 (Beowulf is so regardedby Hrodgar); swaese gesipas 29-men of scyld; the same term applied to the Headobards 2040; Beowulf's men, 2518; men of Đryd's husband, 1934; eode eorla sum...self mid gesidum 1313 -- Beowulf with his band; similarly 1924; (Wiglof) saegde gesidum 2632 -- Beowulf's men (called medu-pegnum 2633). eald-gesid

old comrade: eald-gesidas, swylce geong manig B. 853 .

wil-geaid

familiar companion, dear:-- hine on ylde eft gemunigen wil-gesipas B. 23--his men, warriors. gestealla comrade, only in compounds in Beowulf. eaxl-gestealla

Familiar comrade (Tahslo > eaxl, shoulder); one standing very close, right hand man. In Beowulf:

Dead is Aeschere.... min run-wita ond min raedbora, eaxl-gestealla 1326; breat bolgen-mod beod-geneatas, eaxl-gesteallan 1714. 
hand-gestealla

One whose place is close at hand, an intimate companion, associate. In Beomulf: deat renian hand-gesteallan 2169; Nealles him on heape $h(e)$ handgesteallan aedelinga bearn ymbe gestodon 2596 . lind-gestealla

Shield-bearling comrade. In Beowulf: wigendra hleo lind-gestealla, liflgende cwom 1973. nied-gestealla

Comrade in need. In Beowulf (only): swa hie

a waeron aet nida gehwam nyd-gesteallan 882 . glest (gaest)

Guest, stranger. In Beowulf:- gaest inne swaef 1800 (meaning Beomulf in Hrodgar's court); of 1522-- Beowulf in the den of Grendel's mother, 1138-- Hengest in the home of Finn; 2227 -- a runaway slave; 1602--Beowulf's men who are watching for his return; 1893--Beowulf's party departing from Heorot.

fede-giest

Stranger on foot. In Beowulf: (H) rade waes gerymed swa se rica bebead fede-gesturn flet innanweard 1976 (only). 
sele-giest

Visitor in the hall. In Beowulf: Ofsaet pa pone sele-giest ond hyre seaxe geteah 1545. Beowulf

is in the den of the Grendel kin.

guma, Given under 3 .

seldguma.

A man who always remains in the house. In Beowulf only: nis paet seld-guma waepnum geweordad

249. The word is used by the coast-guard, who is praising Beowulf.

--haga, dwelling, inhabiting. See anhaga

anhaga

A solitary, one living or wandering alone:--enge anhaga, wiga waelgifre (death) Gu.970. In Beowulf: oferswam da sioleda bigong sunu Ecgdeowes, earm anhaga 2368 .

łoga, Iying. See treowloga

treowloga

Compact-breaker. In Beowulf only: holt ofgeafon tydre treow-logan 2847 -- Beowulf's cowardly followers.

scada

One hurt-ful and destructive, a foe (used especialIy of the devil in religious poetry). In Beowulf:-- 
scatan onetton waeron aedelingas fuse to fare(n)ne 1803; cwaed, paet wil-cuman wedera leodum scapan scirhame to scipe faron; cf. also 1. 4, 274 . The word seems equivalent to hero, hardy fighter, who injures his foes.

weard

Guard, protector, lord (Wwer to give attention to). In Beowulf:--se weard swefed sawele hyede 1741-conscience; used of the coast-guard 229, 286; Hrodgar is beah-hordes weard 921, rices weard 1390; Beowulf, folces weard 2513; the dragon, weard unhiore 2415, beorges weard $2580,2524,3066$; cf. a.so 306 and 2841 .

Grein cites the following various uses of weard in OE. poetry: rodera, heofenes, heofena, heofonrices, wuldres, folces, folca, middangeardes. daere burge, rices, brytenrices, gumrices, moncynnes, swegles, gumena, gasta, engla, upengla, lifes, leohtẹs, weredes, mereflodes, wigena, sigores, sigora, worula gesceafta, Babilone, beorges; beaga, beahhorda, hordes, wudubearwes, weges, waeges-weard. The word also appears in prose. eoton-weard Guard against giants:-- sundor-nytte beheold) Jmb 
aldor Dena eoton-weard abead 3.668 (only). Here, the office, not the person, is meant.

edel-weard

Iord of ancestral territory:-- feor eal gemon eald edel-weard 3. 1702--Hrodgar; waes da frod cyning eald epel-weard 2210--Beowulf; pa freolic wif ful gesealde aerest hast-Dena epel-wearde 6I6-Hrodgar.

gold-weara

Guardian of the gold: Ne-meahton we ge-laeran leofne peoden.. paet he ne-grette gold-weardfone

B. 3081--the dragon(the only instance in Ags. Iiterature).

hord-weard

Guardian of treasure, lord. In Beowulf:-- The word refers to the dragon in 1. 2293, 2302, 2554, 2593; hord-weard haelepa B. 1047 -- a king; similarlyl852. ren-weard

Excellent or strong guard:-- Yrre waeron begen refe ren-weardas B. 770 (only) -- reference to Beowulf and Grendel.

vrfe-weard

Hereditary lord; the word is used to mean 'legal heir' in prose. In Beowulf:-- paer me gifede 
swa aenig jre-weard aefter wurde 2731; odres ne-gymed to gebidanne burgum in innan yrfe-weardas 2453 .

wita

Wise man, counsellor; meaning counsellor, leader in affairs of state, the word appears in the chronicle 868. In Beowulf:--Đaes ne-wendon aer witan scyldinga taet a mid gemete manna aenig ...... tobrecan meahte 778 ; ne paer naenig witena wenan forfte beorhtre bote to ban(an) folmum 157; hine gearwe geman witena wel-hwylc 266; witena gehwylcne 936; he fa wea-lafe weotena dome arum heolde 1098-indefinite reference to the sage men of Hrodgar's hall.

wraecca

Exile (wraec an $>$ wrek to drive). In Beowulf:-fundode wrecca gist of geardum 1137--Hengest; wraeccan wine-leasum 3613 -. Eanmund; Se waes wreccena wide maerost ofer wer-deode 898--sigemund. The word is found in prose, too.

wraecmaecg:

Exile, miserable man:-- Hyne wraecmaecgas ofer sae sohtan suna Otheres. B. 2379. 
wundor-smid

A smith who does wonderful work; wundorsmipa geweorc B. 1680 (only).

The following are concrete in so far as they point to somethingexternal and call up images in connection with the name: beod-geneat, heord-geneat, handbana, scada, edelweard, gold-weard, hord-weard, yrfe-weard.

The other words are either so loosely used that the mind does not find for them very difinite defining lines (e.g. weard ), or else the term designates, not the man, but his inner attitude, or his relation to others. The word giest, for instance, does not give rise in the mind to a particular image; it is merely an indication of the relationship between the man and his environment. 


\section{Nouns Indicating Kinship and Family Relations.}

bearn

Son, child, descendant. In Beowulf:--wolde hire bearn wrecan 1546 -. Grendel; similarly 2I21; he his brodor bearn abreāwade 2619 -- Onela's nephew; hord forstandan bearn ond bryde 2956; flem feower bearn .... in worold wocun 59; yldo bearn aefre gefrunon 70; gumena bearn 877; cf. also 878; haelepa bearn 1189; nipta bearna, grund-brepndra 1005; gumena bearna 1367; pegn nat hwylces haeleda bearna 2224; ylda bearnum 150; similarly 605 .

Beowulf-bearn of Ecgdeow 529, 631, 957, 1383, 1473, 1651, 1817, 1999, 2177, 2425; Beowulf-aedelinga bearn 1408; Geata bearn 2184; Beowulf's band: aedelinga bearn $\measuredangle 597$, aepelinga bearn 3170; the same phrase refers to Sigmund 888; Heremod: peodnes bearn 960; Lotena bearn 1088, 1141 -- the Danes? Definite meaning of son 1020, 2387, 1074, 2370, 2433, 467, 499 .

dryht-bearn

Youth of the people, noble:-- ponne he mid faemnan on flett gaed aryht-bearn Dena B. 2035 (only). It is not clear here whether Freawaru or her attendant is meant. ('Braut-führer', Förster says in Anglia Bei. 13, p. 171.)

byre

Son (a word found only in poetry). In Beowulf:-- 
dara banena byre nat-hwylces 2053; (maeru cwen) baedde byre geonge 2018; the word clearly means son in the usual definite sense in 2445, 2621, 2907, $3110,1188$.

eafora

Descendant, son; effsoring, heir, successor, according to B. T. (af from, afar after, abaran, aburan descendant.) The word is found only in poetry. In Beowulf:-- Đaem eafera waes aefter cenned $\$ 2$; Scyldes eafera 19; Waelses eafera 897; Hredles -2357, 2992, 847; cf. also 1547, 2475, 1068, 2520, $1185,1710$.

gaedeling

Comrade, mate, fellow, relative ( 1. gad to hold together). It is a word found only in poetry. In Beowulf:-- him Onela forgeaf his gaedelinges gudgewaedu 2617; Gewat him da se goda mid his gaedelingum 2949 (tribesmen).

maeg

Kinsman: son, cousin, uncle, nephew, brother (descendant, too, e.g., cyninges Cri. 165). In Beowulf: ic eom Higelaces meeg 
ond magodegn 408; min ylara maeg 468 (reference to Heorogar by Hroatgar); maeg wid maege 1978 -- Beowulf and Higelac; swa sceal maeg don 2166; 2628 not clear; ne ge leafnes-word gud-fremmendra gearwe ne-wisson maga gemedu 247 (Thus parallel with warriors, fighting members of the tribe?). Similarly maga rice 1853 -- meaning nephew: 137, 758, 813, $914,1530,1178 .--$

Brother: 2439, 2484, 2982, 2436.-Son: 1339 -. Grendel

Mother: 2006, 2353 -- Grendel's mother Hrodgar and Hroulf 1015 Relationship between Wiglaf and onela 2675 " " and Beowulf 2698, 2879. Son and brother of Hildeburh 1079. iiglaf, maeg Aelfheres 2604 Hemminges maeg 1944(?), 1961 -- Eomer In general 2815, 2742, 1167, 2614, 3065. wine-maeg

Beloved relative. The word appears only in poetry. him his wine-magas georne hyrdon B. 65 -- tribesmen?

maeg-wine

Friendly kinsman (in poetry only). 
paet maegwine mine gewraecan faehde ond fyrene B. 2479 .

maga

Son, boy, man:-- maga Healfdenes (Ecgleowes) B. 189 , 2143, 2587; se maere -- Healfdenes B. 1474; sva pone magan cende 943; se maga geonga 2675 -- Wiglaf; paer àbidan sceal maga mane fah miclan domes 978 magu

Son:-- mago Ecglafes 1467; mago Healfdenes 1867; 2001; ne ge leafneswora gud-fremmendra gearwe ne wisson mago gemedu 247. (Holder regards maga in this last sentence as genitive plural of maeg.)

Sib-aedeling and sin-frea, mentioned in other lists, also convey the idea of kinship.

The word faeder occurs 16 times, modor, 8 times, dohtor 6 times. The nouns of relationship seem to play a rather important part. However the comprehensive term maeg is, of course, the favorite. 


\section{Names for Women}

ewen

1. Woman: cwena selost, Maria, Men.168

2. Wile: B.62, 613, 923, 665 .

In every case here, however, it is the wife

of a king or princeof whom the word is used. Abrahames cwen Gen.2259.

3. Queen: paet hio Beowulfe beaghroden civen mode ge $p$ ungen medo-ful aetbaer B.623; maeru cwen, fridu-sibb folca 2016; seo owen numen 1153. (Why not wife here?)

faemne

Woman, virgin, also one recently married. In Beowulf: se faeman pegn 2059; he mid faeman on flett gaed 2034. The word designates Freawaru.

Freolicu faemne Gen.998 - Eve in the garden; the Virgin Mary in Cri.35.

ides

Female, woman (T.aipi(n), mother?) In Beowulf;

ides Helminga 620 (she is cwen Hrodgares 613); Jaet waes geomuru ides 1075 - Hildeburh; similarly 1117; ides Scyldinga 1168 - Nealhdeo; similarly 1649; ides, aglaec-wif 1259 - Grendel's mother; similarly 1351; ne-bid swylc cwenlic $p$ eaw idese to efnanne 1941.

maegđ

Virgin, woman. In Beowalf: - his cwen mid him... maegda hose 924; swa hwylc maeg pa 943 - referring 
to the mother of Beowulf; swa bia maeg pa craeft) wig-gryre wifes 1283 - the mother of Grendel; ne maegd scyne habban on healse hring-weordunge 3016.

(meowle, woman; S.geomeowle)

geomeowle (jumeowle)

One who was a maiden long ago; an old woman. In Beowulf: sio geo-meowle aefter Biowulfe $\ldots$... song sorgcearig 3150 .

(sib peace; s.fridusibb)

fridusibb (T.frid > fri to love and $\mathrm{sibb}>$ sebjo relationship)

Kinswoman, feminine peacemaker, queen. maerucwen friđusibb folca fleteall geondhwearf B. 2017 (only). wif

Woman, wife. In Beowulf; - freolic wif ful gesealde 615 - Wealndeo; wif unhryre 2120 - Grendel's mother; Hie on sae-lade drihtlice wif to Denum feredon 1158; wig-gryre wifes 1284; fela taera wes wera ond wife 993; cf. Elso 936, 2028. 
By way of commentary, one might list the terms used of Beowulf, alone, always bearing in mind that this is a story of aritocratic society. Thus,

Terms used of Beowulf

Before his kingship

$\frac{\text { After he has succeeded Higelac's }}{\text { son }}$

Jegna betstan

folces weard

gud-beorne sum

edel-weard

rinc (also used of Hrodgar)

wilgiefa

gudrine

hierde

here-rinc

wine

wiga

goldwine

randwiga

gud-wine

merefara

herewisa

giest

sincgiefa

selegiest

folcagend

scealc

wigend

wisa

maga Ecgđeowes

lindges tealla

anhaga

scyldereca

handbana

sweordfreca

winia bealdor

grumarihten

ealdor lalso used

of Hrodgar)

cyning (folc; gud-leod-

fengel

freodryhten

frea

freadryhten

hlaford 


\begin{tabular}{ll} 
Before & \multicolumn{1}{c}{ After } \\
fengel & frumgar \\
geseldat & hildfruma \\
eorl & goldgiefa
\end{tabular}

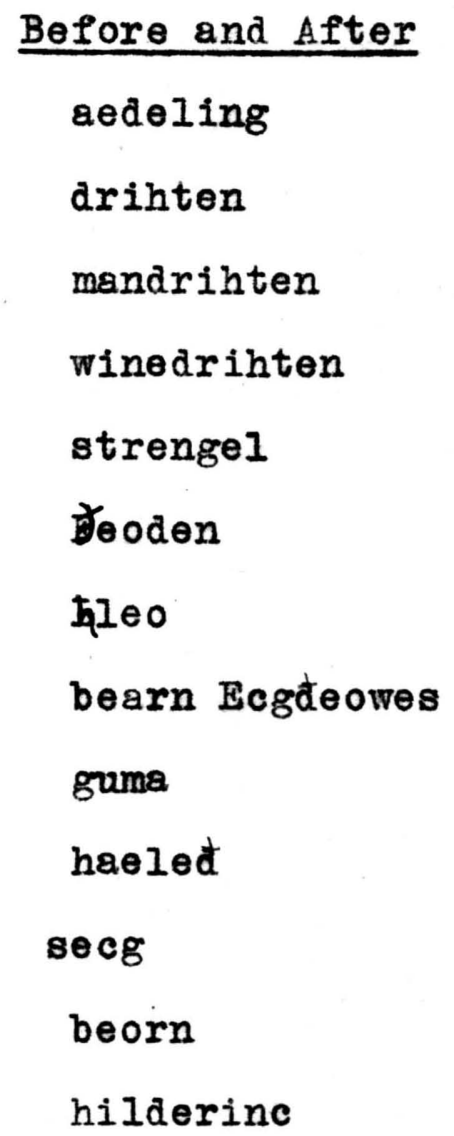

Beside the aristocratic "hero", for which almost every one of the terms in this whole section is, in some sense, a descriptive epithet, the only other classes of society mentioned are those which, in Beowulf, include the names geoman, scop, and 应le, and the smid.

There are, to be sure, the bat-weard, the landweard, the endesaeta, and the ombiht, who seem to be doing some specialized form of military service. But the bat-weard sat on the mead-bench with the others. The endesaeta is 
called weard and ombint, whereas Wulfgar is also ar and ombiht, who is Wendla leod. Bat-weard and landweard mean practically the same thing in 1. 1890 and 1900. Neither of the words appears anywhere else.

"Hyd-weard gearu se pe langetid leofra mannal fus aet farode feor wlatode" might as well mean that one of his men had long been watching for Beowulf. This word, too, occurs here alone.

The seledegn and ombiht degn, as already mentioned, do seem to be names for body or house servants, but the use is too vague for us to decide the question. Sele-degn is not found elsewhere. Ombeht, according to B.T., is translated by the Latin words minister, servus, nuntius, legatus. The sense of menial is not evident. It is surely conceivable that almost any one of the degns would have delighted in offering his services to an admired hero.

Runwita and raedbora are an adition to the concrete vocabulary of the poem in that they do suggest some other function of a warrior than that of fighting. But within their te they serve chiefly to give part of the inner history, of the character, of the man. In his evlogy of Aeschere Hrodgar uses them: Min rind wita and min raedbora eexlgestealla. - - swylc scolde eorl wesan, aedeling aergod. "He was the man who shared my secrets, who gave me counsel, who stood by my side in the fight, who was what an eorl should be, an excellent aedeling."

To the foregoing we must add the nine different words 
which mean "sailor". (This includes nouns in-end). Howover, the sailors are the same men who are called warriors. Beowulf is called fepe-cempa once during the fight with Grendel's mother; as he is returning from the same fight he is spoken of as lidmanna helm. These were men who sailed the seas; the implication is that they were bold men, who were seeking daring enterprises.

Thus we have the warrior set forth in many handsome terms against a shadowy background of society, from which these figures, only, emerge, - the scop, the gleoman, the dyle (and they belong to, or perhaps constitute, a single class), and the smid.

of the scop and gleoman, Merbot ${ }^{1}$ says that the gleoman must entertain his hearer as his name promised; the scop was a man known among the people for exalted work of the intellect and the spirit (hence the original significance of the word - creator, framer). The gleoman was gidda gemyndig; before all things he was versed in music, but his name was used for the poet who went about and sang his own songs and for the singer who sang the songs of others. The scop was a poet and then a singer of his own poetry. The dyle was an orator; Heyne says that he led the conversation about the court. Of the smid we have mention twice, and then once more in the term wundor-smid, where the poet in his admiration for the golden sword calls the man who fashioned it "a maker of wonders."

${ }^{1}$ Aesthetische Studien Zur. Agr. Poesie. 
After reading Beowulf for the mere enjoyment of the epic narrative, without any desire to account for it all, one finds it hard to agree with the critic that a large number of the words have been introduced merely to please one's ear with recurring sounds and changes of sound. Still it is manifest that those 54 names for chief or king and the 19 different terms which must be translated warrior have added no figures to the picture, nor has the variation, so far as the root meanings show, made the person of whom the term is used, always more concrete and clear - even to the AngloSaxon audience, we must think. One has a strange feeling that a very real person is sailing for Heorot, is fighting with Grendel, is dying finally after a noble struggle, but that a veil has in some way been drawn over it all. The narrator, in the rapture of paying honor to his hero, has avoided that hero's name in order to lavish upon him stately epithets. The sonorous procession of the kennings is devised to give us pause that we may appreciate the truly heroic nature of these heroes.

Of the absence of other concrete figures, one might say with Howell $I^{1}$ that the poem is "full of Absences", the absences of the men who set the bounteous table of Heorot and prepare the mead that the warrias might know "hall-joy", the absence of the men who tilled the soil (Chadwick ${ }^{2}$ says that there was early a highly developed agriculture here), 
indeed the absence of the whole life of the men when they laid aside the spear. Contrast with this world, the gay variety of figures which move through a small part of a single book of the Iliad, the minstrels, the herdsmen of kine, the herald, the daysmen, the scouts, the hinds reaping, the sheaf binders, the henchmen who are making ready the feast, the vintagers, the boy playing a viol, the potter, the tumblers, the men and women dancing of Bk XVIII (Iang-Leaf-Meyer translation. We feel that many of these characters are present in Beowulf, but we cannot see them. Beyond the little group of the heroes with their vague setting of heord-genedtas, the picture of society fades quickly out into the dim regions of the fold-buend and the sawol-berend. 


\section{B. Group Terms}

This section is divided again on the basis of size intolithe more comprehensive terms, coinciding fairly with the names for family or tribe, and (2) the narrower terms, designating military bands. However, it is not to be forgotien that most of these groups grew first out of the family. Stjerna*, even, in his discussion of Beowulf's band of twelve, says that "the number twelve often refers in the older Northern poetry to brothers or foster-brothers who go on warlike expeditions in company."

cyn

Genus, the number of all beings of one kind, race, people, nation, tribe, family, progeny. In Boowulf:- Wedera cyn 461; Fresena cyn 1093; eotena cyn 421, 883; giganta cyn 1690; manna cynnes 701; similarly 810, 712, 914, 1725, 735; gumena cynnes 1058; maeran cynnes 1729; ladan cynnes 2354, 2008; ae $p$ elan cynnas 2234; usses cynnes 2813; Caines cynne 107; Eowrum cynne 2885; (god) lif eac gesceap cynna gehwylcum 98 . 


\begin{abstract}
feorh-cyn
Race of the living (a word found only in poetry.) In Beowulf:- Bealo-cwealm hafad fela feorh-cynna f(e)ord onsended 2265.
\end{abstract}

fifel-cyn

Race of sea monsters: fifelcynne eard wonsaeli wer weardode hwile B. 104 (only).

frum-cyn

Origin, race, tribe: nu ic eower sceal frum-cyn witan B. 252. (The word is found only in poetry.) This is rather an abstract than a group name, in Beowulf.

gum-cyn

Race of men, folk (it juetry only). In Beowulf:- We synt gumcynnes Geota leode 260; Sinc ead'e maeg ....gum cynnes gehwone oferhigian 2765; cf. also 944.

mon-cyn

Man-kind. In Beowulf, the word occurs six times (196, 1955, 164, 1276, 2181, 110), eg., se waes moncynnes maegenes strengest 196. 
wyrm-cyn

Race of serpents: gesawonta aefter waetere wyrm-cynnes fela B. 1425.

folc

People, race, nation, men (homines): the Heyne-Schllcking glossary translates the word "Volk im Sinne der Gesamtheit der streitbaren Manner einer Nation." In Beowulf:- Sud-Dena folc 463; similarly 465, 1583; he gesishte swaesne edel leof his leodum lond Brondinga freodo-burh faegere paer he folc ahte 522; Flod blode weol (folc to saegon) 1425; hu da folc mid him faehde towehton 2948; similarly 55, 262, 1856; wine folca 430, 2358,2430 ; folc ond rice 1180; 28 instances of use in the poem.

sige-folc

Victorious people (a word found only in poetry): đeod on saelum sige-folc sweg B. 644. 
leod

People, men: Fbrsterl says, "Ebenso
sollte leode nicht mit unbestimmten
ausdrucken wie'die einzelnen eines
volkes, leute, stammgeonossen'
wiedergegeben, sondern deutlich als
standesbegrift (gemeinfreie) ge-
kennzeichnet werden."
\[ \text { In Beowulf: leode Deniga } 599 \text {; } \]
Wedera leode 225 ; Geata leode 260 , etc;
the word occurs fifty-eight times in
the poem.

maegburg

Family, tribe, stock, race: maegburge ........ mine (my children) Rid. 1620; Gieldan siđdan his maegas đone wer gif he maegburg haebbe I. In. 74. In Beowulf:- lond-rihtes mot paere maegburge monna aeghwylc idel hwearfan $288 \%$.

maegd

Tribe, nation, race, family. Chadwick says, "We may infer, no doubt, that the 1. Anglia Beiblatt $\nabla .13$, p. 166. 2. Origin of the Eng. Nation p. 155. 
word originally conveyed the idea of blood-relationship ....... Either the word may have lost its original significance in this sense--with which we may compare the use of gens in Latin--or it may have denoted primarily the royal family."

Försterl: "Unter maegd sollte man sich nicht mit einem blossen "stamm, volk" begntlqen sondern angeben dass technisch maegd die 'gesamtheit der agnatischen blutsverwandten, ' oder 'die Sippe' bedeutet .........". The word is a law term.

In Beowulf:- ne gefraegen ic pa maeg pe maran weorode jmb-hyra sinc-gytan sel gebaeran 1011; lofdaedum sceol in maeg $p a$ gehwaere man ge peon 25; scea pena preatum monegum maeg $p$ um 5; hig wigge beleac manigum maeg $p$ a 1771 .

deod

Folc, race, nation: on peode (among men) Gn. 1204; peoda gehwam (every one 1. Anglia Beiblatt, v. 13, p. 165 . 
on earth) Gen. 64l; pioda aldor Ps. C. 26. In Beowulf:- jegnas $\operatorname{syn}(d \circ n)$ ge $p$ waere peod eal-gearo; druncne dryhtguman dot swa ic bidde 1230 (aeghwylc eorl 1228); waes seo feod tilu 1250 (Beowulf's band of 15?); paet waes fremde peod ecean dryhtne 1691 (giganta cyn 1690); peod on saelum sige-folca sweg 643; Blaed is araered geond wid wegas . . . ofer feoda gehwylce $170 b$. Chadwick ${ }^{1}$ describes the feod as a boay of warriors, young and old, attached by personal service to the king. It meant not only 'people,' 'nation; but also in particular the court or council of the king. Chadwick cites $B$. $644,1231,1251$ (643, 1230, 1250 according to Holder's numbering).

sige-peod

Victorious people; the wor appears only in poetry. da hyne gesohtan on sige- peode. hearde hilde-frecan B. 2204 .

1. Origin of the Eng. Nation p. 311 and 157. 
wer- peod

Nation, people (another word used only in poetry.) Se waes wreccena wide maerost ofer wer-peode B. 899.

cordor

Troop, company, cohort (T. Kar to turn, direct, kur(ara troop). The word appears

once in the Chronicle 973: Her Eadgar

waes Engla waldend cor 7 re micelre ("in

this year wagar became ruler of the

Angles with much pomp".) In Beowulf, swilce

Fin slaegen cyning on cor pre 1153; Huru

se snotra sunu Wihstanes acigde of cordre

cyninges pegnas 3121. (The term appears

to be only poetic.)

(aryht, people, family, multitude; the

simplex is not in Beownlf.)

maguariht

Multitude of jouths (T. magu son, boy).

In Beowulf: od paet seo geogud geweox, magodriht micel 67 (only).

Förster* says, "Ae. dryht be-

zeichnet im Beowult in erster linie

*Anglia Beiblatt, v. 13, p. 167. 
'die gesamtheit der gefolgsmannen die inrem herrn eidlich treue und gehorsam sowie kriegsfolge versprochen haben." The word here discussed appears only in compound in Beowlit but gedryht is doubtless closely related in meaning. According to wright, ge- (meaning originally 'together') was especially used in forming collective nouns. See gedriht.

dugud

I) Nanhood and those who have reached that age.

2) Men, army, people.

3) Heavenly bands.

seo hea dugud and se engla drym Cri. 1063; cf. also Exod. 546, Gen. 81. Chambers in his introduction to the Wyat and Chambers edition of Beowulf ${ }^{2}$ says of dugup "Thus dugupsignifies doughtiness, excellence; again it signifies that body ofretired veterans from whom the quality of dugup is particularly to be expected. We can hardy translate dugup simply as

1. Ola English Grammar p. 290, sec. 574. 2. p. XXXIV. 
warriors; for the abstract meaning reacts upon the concrete; they must be doughty warriors. A very close parallel is supplied by the English word 'chivalry' though here the original sense is concrete." Chadwick ${ }^{1}$ writes that the court, it is clear from Bede's writings, consisted roughly of two classes, which we may perhaps describe as 'seniors' and. 'juniors' (dugut and geogod).

$$
\text { In Beowulf:- Ealle hie dead }
$$

fornam aerran maelum and se an đa-gen leoda dugude se daer lengest hweart 2238; paet naeron eald-gewjrht paet he ana scyle Geate dugude gnorn prowian 2658; nalles fraetwe geaf ealdor dugude 2920; Hwilum for dugude dohtor Hrodgares eorlum on ende ealu-waege baer 2020; se goda com leoda dugoda on last faran 2945 (called earmre teohhe 2938 and flot-herge 2915); dryht-bearn Dena duguda bi-we(r)ede 2035 ; dugudelior scoc 2254. Add to the foregoing the three ocm 1. Origin of the Eng. Nation, p. 157. 
casions in Beowult where the word has its abstract character: sydđan ic for dugedum Daegrefne weard to hand-bonan 2501; cude dugude peaw 359; his ellenweorc dugudum demdon B. 317b.--It should be noted here that there is some doubt about the meaning of for dugudum in 1. 2501. Chambers ${ }^{1}$ says, "It is not clear whether for dugudum means 'by reason of my valor' (cf. 1. 1206 for wlencol, or whether it means 'in the presence of the doughty (cf. 1. 2020 for dugude)" Sedgefield expresses the same doubt. Gummere and clark Hall in their translations declare for the-abstract sense; Schllcking and Grein give the more concrete meaning.

gedrint

Company, troop (in poetry only). In

Beowulf: minra eorla gedryht (and) pes hearda heap 431; Fand pa daer inne aepelinga gedriht 118; paer Hrodgar saet eald ond unhar mid his

1. Wyatt Chambers Beowulf, note to 1. 2501. 
eorla gedriht 357; pa ic on holm gestah sae-bat gesaet mid minra secga gedriht 633; Đa him Hropgar gewat mid his haele $p$ a gedrght 662; secga gedryht ond pegna gehwylc pinra leoda augude ond iogo pe 1672

sibbgearyht

A troop of one mina, peaceable (according to Grein). B. T. translates the word 'a band of kinsmen' and then, 'a peaceful band." Fbrster says 1 " (Ich glaube) dass ae sib(be) gedryht nicht 'eine in freundschaft verburdene kriegerschar' bedeutet, sondern die technische bezeichnung fur jene 'durch blutsverwandschaft verbundene heeresabteilung' war, wenn auch in den beiden stellen im Beowulf (v. 387 u. 729) der urspr. verwandtschaftiche begriff auf das verhaltnis der gefolgschaft tbertragen erscheint."

In Beowulf: Beo du on ofeste, hat in gan seon sibbe-gedriht 387--Beowulf's band; Geseah he in recede rinca manige swefan sibbe-gedriht samod aet-gaedere mago-rinca heap 729 .

1. Anglia Beiblatt, v. 13, p. 166. 
In $\mathrm{Ph} .618$ the word is used of the spirits in heaven.

geogud

Youth, goung age, young men. In Beowulf:fa waes Hradgare here-sped gyfen wiges weord-mynd paet him his wine-magas georne hyrdon odd- paet seo geogod geweox 66; Hređric ond Hrodmund ond haele $p$ a bearn giogod aetgaedere 1190; dugupe ond geogope 160, 621, 1674; faet he fa geogode wile arum healdan 1181; gomel gud-wiga giogudecwidan 2112 (lamented over his youthful days); similarly 409, 466, $2512,2426$.

getrum

Army, troop (T. tru to be firm):- he gewat mycle getrume An. 707; under tungla getrumum sol. 142. In Beowulf: tryddode getrume micle 922.

heap

1. Multitude or abundance of things. waelnota heap (many fatal signs) Sal. 161 . 
2. Multitude, troop, army: halgan heap (apostles) Ap. 9; meaning"his chosen ones" Ps. $104^{38}$. In Beowult:- ymb hine rine manig prydlic pegna heap B. 400; similarly 1627, minra eorla gearyht (ond) pes hearda heap 432; swefan sibbe-gedryht . . magorinca heap 730; HengesTes heap 1091; nealles him on heape $h(e)$ andgesteallan aedelinga bearn ymb-gestodon 2596; heresceafta heap 335 (not of persons but of things.)

wig-heap

War troop;-Is min flet-werod wig-heap gewanod B. 477 (only).

here

Multitude, troop, army. According to B. T. it is a word which in the chronicle is always used of the Danish force in England, while the English troops are always the fyrd. Forster" says, "Bei ae, here pflegen *Anglia Beiblatt, v. 13, p. 166. 
wir uns mit der Hbersetzetzung 'heer, kriegsvolk' zu begntlgen, was gdnzlich falsche vorstellungen her vorrufen muss. Vielmehr bezeichnet das wort 'die gesamtheit aller waffentghigen wanner eines volkes."

In Beowulf:- fone wid-flogan weorode gesohte sidan herge; anwig-gearwe ge aet ham ge on herge 1248 ("on an expedition"?); he usic on herge geceas 2638. Forster poinus to this last sentence.

flothere.

Naval force. In Beowuli: Hygelac cwom faran tlot-herge 2915.

sin-here

An immense army. In Beowulf: Besaet sinherge sweorda lafe 2936 (only).

hos

Crowd, troop. In Beowulf: und his cwen mid him medo-stig gemaet, maegda hose 924 (only). (troop. Whe simplex does not appear in Beowult.) 
hand-scolu

Turma amanuensis: troop, retinue, men who

fought with their hands. In Beowulf (only):Gang da aefter flore fyrd-wyrde man mid his hand scale 1317 (self mid gesidum 1313); Gewat him da se hearda mid his hond-scole 1963.

teohh

Social intercourse, society, troop, multitude:- eallum fam teohhe, fe nu toweard is ("to all the generations which are to come")

Ps. 70. The word looks back to the prim. Ger. teh to order. In Beowulf:- besaet da sinherge sweorda lafe wundum werge, wean oft gehet earmre teohhe 2938 .

đreat

Congeries, multitude, troop. (T.prut to press, burden) on preatum (in chorus) Ps. 149; wuldres preat (angels) An.872. In Beowulf:Se waes on đam dreate preotteoda secg 2406; oft scyld sceting sceapena preatum mongeum maeg $p$ um meodo-setla ofteah 4. 
iren preat

Armed troop:- waes se iren freat waepnum gewurfad B. 330 (only)

werod

Troog, folk, throng:- engla weoruide El.

1280; fore weorodum ("before the multitudes")

An. 737. In Beowult:- werod eall aras 651

(the company in Hrodgar's hall: deod on

saelum 643); Ic paet gehyre paet pis

is hold weorod frean scylainga 290 (Beowulf's

band); weorod waes on wynne, ne-seah ic widan

Ieorh under hoofones nwealf heal-sittendra mudedream maran

2014; weorod eall aras eodon unblide 3030

(called eorl-weorod 2893); Ic to sae wille

wid wrod werod wearde healdan 319; werodes

wisa zby; Ne-getraegen ic $p a$ maeg $p$ e maran

weorode ymo hyra sinc-gytan sel gebaeran

1011; he fone wid-flogan weorode gesohte

sidan herge 2346; Wealhdeo mapelode, heo

Iore faem werede spraec 1215. (the company

in the hall?); drinten wereda 2186 ; weoroda

raeswa $\langle n\rangle$ Heorogar onä Hrođgar ond Halga

til 60 . 
eorl-werod

$$
\begin{aligned}
& \text { Milidur troop:- oter e } \bar{c} \text {-cili faer } \\
& \text { faet eorl-weorod morgen-longne daeg } \\
& \text { mod-giomor saet B. } 2893 \text { (only). Here is } \\
& \text { meant that part of Beowulf's men that } \\
& \text { were not among the number chosen for the } \\
& \text { fight with the tire arake. }
\end{aligned}
$$

flet-werod

Court-host, court retainers:- Is min fletwerod wig-heap gewanod B. 476 (only)

$$
\text { For the sake of comparison I sub- }
$$

join the following arrangement of the words in this section.

The band of fifteen which accompanied Beowulf to Heorot is called

Geata leode

secga geâribt

eorla gedrint

sibbe-gedriht

handscoln

pegna heap

irendreat

weorod

seo peod tilu 
Those who make up the party of twelve in which Beowulf went against the fire arake are

dreat

cordor (?)

eorl-weorod

In references to the men in Hrodgar's hall are found the terms

maeg

$p$ eod ? $)$

eorla gedriht

magodriht

geogeduat

augud

flet-werod

wig-heap

getrum

werod.

Between the two very common words,

fole and leod there seems to me this faint

distinction, that in the word fole the

collective sense is stronger. Only a

survey of the whole poem eould establish 
this with true clearness, but one may point out that such combinations as folc and rice (1180) folc opde freo-buch, (693), folces hyrde (610) are common, whereas leod is used more loosely as "Ic pa leode wat ge wid Geond ge wid freond faeste geworhte" (1863). However, one may easily push the distinction too far here, for, as I have just said, it is of the faintest. The meaning of feod is more vague than that of either of the foregoing because as has already appeared, it may denote the "giganta cyn."

In conclusion, it is worth noting that cyn, (and consequently all its compounds), maegd, dugud, and googud are abstract formations. 


\section{Iiving Creatures, Other Than Human Beings}

$$
\text { Division of the section: 1) animals, 2) birds, 3) }
$$

beings having supernatural powers, 4) general descriptive terms by which these creatures are often designatea.

\section{$\underline{I}$}

deor

Wild animals (as distinguished from domestic animals and birds). The simplex does not amnear in Beomulf. mere-deor and sae-deor

Sea beast or monster. In Beowulf only haedo-raes fornam mihtig mere-deor purh mine hand 558; saedeor monig hilde-tuxum here-syrcan braec 1510. wil-deor

Monster. In Beowulf: oft bewitigad sorhfulne sia on segl-rade wymas ond wildeor 1430 .

eofor

Boar; mentioned only as an image ornamenting the crest of the helmet: eofor irenheard B. III2; cf. also 303 and 1328. An eofor-spreot, boarspear, is named in 1437 . heorot

Hart: Deah- pe haed-stapa hundum geswenced, heorot hornum trum, holt-wudu sece 1369. hrom-fix

Whale: wit une wid hron-fixas werian pohton $B 540$. 
hund

Dog: haed-stapa huridum geswenced B 1368.

swin

Boar; again merely the image on the helmet; swyn eal-gylden eofer iren-heard 1III; swin ofer helme 1286.

wicg

Horse; Bosworth-Toller's dic tionary asserts that this is a poetical word - to be translated 'steed'. In Beowulf:- fa wes Hrodgare hors gebaeted wicg wundenfeax 1400; gud-beorna sum wicg gewende 315; cfalso $234,286,2174,1045$.

wulf

Wolf:- he (hrefn) wid wulf wael reafode B 3027 . wyrm

Serpent, dragon; this word in Beowulf denotes the firedrake. The single exception is that of 1. 1430: wyrmas ond wildeor (nicros 1427, wyrm-cynnes fela, sellice sae-dracan 1425). Meaning the fire-drakewyrm hat gemealt 897; Đa waes daeg sceacen wyrme on willann; wyrmes wig wide gesyne 2316 (lad lyft-floga 2315); he wid pam wyrme gewegan sceolde; 2519 wyrme, as against aglaecan 2520; wyrmes denn, ealdes uht-flogan 2759; wyrm irre cwom atol inwit-gaest 2669 ; wyrm onwoc ... stearc-heort onfand feondes fotlast 2287. The word occurs 22 times in Beowulf. In prose it has a very loose use, signifying in one place 
reptile, serpent, and in another creeping insect, worm, even book-worm.

II

earn

Eagle:- Earna-naes B. 3031 (a proper name); se wonna hrefn ........ earne secgan hu him aet aete spe ow 3026 .

fugol

Bird:- flota famiheals fugle gelicost B. 218; sum(eł on galg-treowu(m) fulgum to gamene 2941 (Thorpe)-.. An emended passage.

ganot

Gannet: ofer ganotes baed B. 1861 - the sea. The phrase 'ganotes baed' is used for the sea in Chron. 975 (Edgar 46). It is a poetical phrase. The word is also translated sea-fowl, water-fowl, fen-duck.

hafuc

Hawk:- he god hafoc geond sael swinged B. 2263. hrefn

Raven:- op-paet hrefn blaca heotones wynne blidheort bodode B 0801; ac se wonna hrefu fus ofer faegum fela reordian 3024; ponne his sunu hangad hretine to hrođre 2448 .

\section{III}

deoful

Devil; Grimm ${ }^{1}$ says, "Der name teufel is undeutsch...

1. "Deutsche Mythologie", Vol. 2, pp 824-825. 
das diabolus der vulg. lautet aber bald tiubil, tieval, bald diuval diufal (ago. deofol) und wird zugleich fur da daemonium der vulg. verwende $\ldots$... Nach sei nem innern princip heisst der teufel der böse, feindliche, unholde." He evidently regards not only the word but the idea as properly for ei gn: "Die vorstellung des teufels und teuflischer geister, welche allmählich auch in dem volksqglauben so grossen umfang gewonnen und sofeste wurzel geochlagen hat war unserm heidenthum fremd .... Einen durch-dringenden idealistischen unterschied zwischen gutem und bösem geist... kennt weder die indische und griechische, noch die deutsche Götterlehre"! In Beowulf:- (he) wolde in heolster fleon secan deofla gedraeg B. 755; aefter deofla hryre 1680; sio wais ordoncum eall gegyrwed deofles craeftum 2087.

araca

Dragon: Grimm2 says, "Die schlange kriecht oder ringelt sich auf dem Boden, stehn ihr flügel zu gebot, so heisst sie drache, was ei $n$ undeutsches, aus dem lat. stammendes schon früh eingefuhrtes wort ist. die Saem. edda hat nur einmal dreki .. sonst steht dafür

$$
\begin{aligned}
& \text { 1. "Deutsche Mythologie", Vol. 2, p 822. } \\
& \text { 2. "Deutsche Hythologie", Vol. 2, p 573-575. }
\end{aligned}
$$


ormr, ago. wyrm, welches allgemeiner auch di e schlange mit-begreift." "Von den drachen war nun die herrschende vorstellung des altertums ...... Wie die Romer gigas so ent-lehnten sie auch draco von den Griechen, da für den begriff weder serpent noch vermis ausreichten". He goes on to show that the sense of "shining Iight" exists in the Greek word.

In Beowulf:- draca mortre sweatt 892 (the one killed by Sigmund); draca ricsian se de on heaure haep e hord beweotode 2211; dracan fellum 2088; ne-meahte horde neah $\cdots .$. deop gedygan for dracan lege 2549 ; dracan ec scufun, wyrm ofer weall-clif, leton weg: niman ..... fraetwa gyrde 3131 ; 1. 2290, 2402 contain a mere mention of the word without descriptive details.

eord-araa

Dragon dwelling in the depths of the earth:- sio wand ongon him se eord-draca aer geworhte swelan ond swellan 2712; egeslic Tord-draca B 2825 (only).

fyr-draca

Pire-drake:- pa waes peod-sceada .... frecne fyrdraca, faehta gemyndig: B 2689 (only).

leg-araca

Iig-draca

Dragon vomiting flames:- Haefae lig-araca leoda faesten .... eord-weard done gladum forgrunden B. 
2333; wae se leg-draca grimlic gryre gledum be\$swaeled 3040. In Beowulf only.

nid-draca

Molesting dragon:- se-đe byrnende biorgas seced nacod nid-draca nihtes fleoged fyre befangen B. 2273 (only)

sae-draca

Dragon, or serpent of the sea:- wyrm-cynnes fela sellice sae-dracan sund cunnian B. 1426 (only). ent

Giant:- $\boxplus a$ waes Gyldenhilt $\cdots \cdots \cdots$ on hand gyfen, enta geweorc B. 1679; seah on enta geweorc B. 2717; $\boxplus a$ ic on hlaewe gefraegn hord reafian eald enta geveorc B. 2774 .

That use of the word in connection with building is common, witness, - stapulas standan storme bedrifene, eald enta geweorc An. 1475; paet burg-wara ....... eald enta geweorc idlu stodon Wand. 87; enta aergeweorc innan burgum An. 1235.

Grimm ${ }^{1}$ coments thus: "Ein ags, ausdruck fur riese ist ent, pl. entas, Aelfred im Orosius p. 48 uberträgt Hercules gigas durch 'Ercòlse ent'. die dichter setzen das Wort gern, wenn von alten bauten und arbeiten die rede ist".

1. "Deut sche Mythologie", Vol. 1, p 434. 
In Paul's Grundriss der Germanischen Philologie (V. 3, p. 300) appear this statement: "Ferner erscheint im ags. die Bezeichnung ent, to welchem Worte sich das baierische enzerisch, enzionisch 'ungeheuer gross' geselit."

eoton

Giant Tet to eat; etuna giant--really man-eater?)

In Beowulf(only):- eoten waes ut-weard eorl furdur stop 761; ealle onwocon eotenas ond ylfe ond orcneas, swylce gigantas pa mid Gode wunnon 112; ydde eotena cyn 421; haefaon eatfela eotena cynnes sweordum gesaeged 883. Where the word is capitalized it is not included here. of giants Grimm says", "Die riesen sind von allen die ältesten geschöpfe und gehören dem steinalter an. Hier muss der satz weiter ausgefuhrt werden das die riesen und titanen die alten natur-götter sind".

gigant

Giant (cf. gigas):- eotenas dond ylfe ond orcneas, surylce gigantas B. 113; giganta geweorc 1562; giganta cyn 1690 .

ielfe (ylfe)

Elf:- panon untyaras ealle onwocon eotenas ond ylfe B. 112 .

Golther"says of elves: "Die Elbe golten meist als schön und licht, besonders die Elbinnen sind stets 
von strahlender Schönheit. . . Die Elbe sind wohlgebilaet, ebenmäs $₫ i g$, nur gewöhnlich klein und winzig gedacht. . Das ags. Eigenschaftswort aelfsciene, elbschön. . . bezeichnet die vollkommenste weibliche Schönheit". The singular is aelf; aryades--wadu-elfen; naiades--sae-elfen, in $\mathrm{Wr} . \mathrm{gI}$.

nicor Sea-monster; Grimm ${ }^{2}$ says (of niceras), "es werden ungeheuer geister verstanden die im Meer hausen; Golther" Das wort findet ebenso auf elbische (besonders im Feminimum Nixe") wie auf riesische Wesen Anwendung." In Beowulf:- (Grendel) on nicera mere faege ond geflymed feorhlastas baer 845; ydde eotena cyn ond on yđum slog niceras nihtes 422; ic mid sweorde ofsloh niceras nigene 575; nicras licgean da on undernmael 1427. Murray says in the "New English Dictionary" that nicker in I. E. meant mermaid.

orcne Larva (translated by Harper hobgoblin or monster) (T. urka monster). eotenas ond ylfe ond ornceas B. 112 (only). All these are represented as born of Cain. scinna Demon, one who injures (synonymous with sceada) hie leoda langeweorc la $p$ um beweredon scinnum ond scurceum B. 939. 
spucear

Devil, demon (T. sknh to terrify). cf. B. 939. pyrs

Giant (R. prer to turn about, move): wid parn aglaecan ana gehegan, ding wid pyrse B. 426.

wif

s. Names for Vomen

mere-wif

Giant woman awelling in the lake: Ongeat se goda grundwryrgenne, mere-wif michtig B. 1519(only) aglaeca iv

Monster, huge fighter, author of evil (T. agla, aglu painful, offensive): the word is also used of hero as we have seen. In Beowulf:- atolkglaeca 732 and 592 (manscata 738, feond 725); selaglaeca 159 (deorc deat-scua 160); paer him aglaeca aetgraepe weard 1269; das ahlaecan blodge beadufolme 989 ; the term denotes both Grendel and the dragon; cf. also 433, 592, 816, 1512, 2557, 646, $2520,2534,2905,556,2492$.

andsaca

Adversary (T. and againct, sak to contend). In

Beowulf:- pa pas worold ofgeaf gromheort guma godespanasaca 1682-Grendel; gryre leot galan godes ondsacan 786 . 
dead-scua

Shadow of death or death-bringing spirit, or one surrounded by the shalow of death:-deorc deap scua dugute ond geogope seomode ond syrede B. I60 (only) Grendel.

ealdor-gewinna

One who mennaces life, deadly foe (T. ven to fight against):-him on efn liged ealdor-gewinna siexbennum seoc B. 2903.

feond

Enemy, foe; ased especially often of the devil. In Becwulf: od-daet an ongan fyrene fremman, feond on helle IOI; feond man-cynnes I64 -Grendel; referring to Grendel also in 725, 748, 970, I276, 279, 962, I273 (called helle-gast I274), 984, I43, 439; Grendel's tribe 698, I669, 808, Grendel's mother 2I28; the dragon 2706; in a general sense: Ic da leode wat ge wid feond ge wid freond, faeste geworhte I864; ic magu- pegnas mine hate wid feonda gehwone....arum healdan 294; he (Heremod) weart on feonda geweald ford forlacan 903; stearcheort onfand feondes fot-last 2289; similarly II52, $267 I$.

feorh-genidla

One who seeks his enemy's life, a deadly foe (T. ferhvu body, life, nif envy, malicel. In 
Beowelf (only); no ic him faes georne aet-fealh feorh-genidlan 969; pa he gebolgen waes, feorhgenidlan I540; ond pa folgode feorh-genidlan 2933. Cf. also 288I.

(floga, only in compounds).

gud-floga

Flying warrior, dragon:-Ic eom on mode from aet ic wid pone gud-flogan gylp ofer-sitte $B$. 2528 (only).

lyft-floga

One flying in the air:- no daer aht curices lad lyft-floga laefan wolde B. 23 I5 (only) - the dragon.

uht-floga

Twilight flyer ( $T$. unhtj early morning):paes wyrmes denn ealdes uht-flogan B. 2760 (only). wid-floga

Far-flyer. In Beovelf (only):- se wid-flogan wundum stille hreas on hrusan 2830; Oferhogode da hringa fengel paet he fone wid-flogan weorode gesohte 2346 .

gast

Spirit (T. gis to stir within). In Beowulfsyd $p$ an hie paes ladan last sceapedon, wergan gastes I33; similarly I747; no hie faeder cunnon, hwarder him aenig waes ... dyrura gasta I357; he fone feond ofercwom, gehnaegde hellegast I274; 
Iig ealle forswealg, gaesta gifrost II23. ellor-gast

Alien spirit, one dwelling elsewhere. In Beowalf:se ellor-gast on feonda geweald fear sidian 807; se ellor-gast oflet lif-dagas (Grendel* I62I; similarly I6I7; swylce twegen micle mearc-stapan moras healdan, ellor-gastas I349-Grendel and his mother. (In Beowulf only). (genge(adj) going s. an-genga and sceaden-genga) angenga

Lone-goer. In Beowelf, eted angenga unmurnlice mearcad morhopu 448; atol angengea I65 (feond man-cynnes I64). The word appearsonly in Beowelf.

sceadu-genga

One who walks in the shadows:- Com on wanre niht scridan sceadu-genga B. 703 (only).

giest

The word means 'guest' in the first place, as we have seen; then it comes to mean 'hostile comer', 'enemy'. In Beowelf; gryrelicne gist I44I; se grimma gaest IO2; gaest yrre cwom 2073; se gaest ongan gledum spiwan 23I2. gryre-gist

Horrible comer, foe:- Bicm under beorge bordrand onswaf wid dam gryre-gieste B. 2560 (only). 
inwit-giest

Malicious stranger:- wyrm yrre cwom, atol inwitgaest B. 2670 (only) - the dragon.

nid-giest

Wolesting stranger:- he done nid-gaest niodor hwene sioh B. 2099 - dragon.

Wre 1 -giest

Death-br nging stranger. In Beowulf(only):Weard him on Heorote to hand-banan, waelgaest waefre 1351: ic de lange bald, paet du pone wael-gaest wihte ne-grette 1995.

(gramheart) guma

One who is hostile in heart:- a pas worold ofgeaf gromheort guma, rodes ondsaca B. 1682. The general word guma is thus qualified by an adjective. grund-wiergen(wyrgen).

Female wolf dwelling in the depths (T. very Ig. vergh to blind, throttle, choke). Ongeat pa se goda grund-wyrgenne, mere-wif mintig B. 1518 (only). hellrune

Hellish devil? Grimm ${ }^{2}$ says that helrune signifies "personlich furia, parca, todes-botin". (T. ru to murmur, whisper). In Beowulf(ony): aeglaca deorc dead-scua sinnihte heold, mistige moras; men ne curnon hwaer helrunan hwyrftum

1. "Deutsche Mythologie", p 1025, Vol.2. 
scridad I63.

heortwearh

Blood-thirsty wolf (T heru sword, and verg to blind: varja, wolf). (Grendel heorowearh hetelic B. I267. Warg, wolf, I hiess der Geächtete in der germanischen Rechtosprache".

lat

(As already shown, Mr. Scheinert includes this word in his lists of adjectives used as nouns. It is repeated here because it appears in this connection). Hateful, inimical; an enemy. In Beowalf:- ic mid grape sceal fon mid feonde ..... lat mid ladum 440 (in the general sense of foe); hie daes ladan last sceawedon I32; similarly 84I; wrecemed pa-gyt lidfe aefter Iadum I257-Grendel; Wyrm on wonge. . Iat ne Iicgean 3040 - the dragon; on Iand Dena ladra naenig mid scip-herge scedtan ne-meahte 242; similarly 550, 938.

lad-geteona

Anthor of injury (T. tua to draw (?); an enemy. In Beowrif (only):- no py leng leofad lat-getteone syn-num geswenced 974 (Grendel, who had been killed by B. ); Swa mec geloma lategeteonan preatedon pearle 559.

(I) Golther, Handbuch der Germ. Mythologic p.IO2 
manfordaedia

Destrejer (cf. fordon to destroy):- Naes hie daere fylle gelean haefdon manfordaedla B. 563 (only)sea-monsters.

mearc-stapa

One who wanders over the boundary lands. In Beowulf (only):- waes se grimma gaest Grendel haten, maere mearcstapa I03: daet hi gesawon swylce twegen, maere mearc-stapan moras healdan, ellorgastas I348.

scada

Enemy, warrior (Tskat to injure); the word seems to mean also 'fighter' and then 'hero'. In Beowulf: mid scyldingum sceatena ic nat hwylc deogol dead-hata 274-Grendel. The passages in which the wordl is applied to warriors have been quoted in another section.

ator-scada

Poisonous foe:- He wit attor-sceatan orede geraesde B. 2839 (only).

dolscada

Desperate foe (T. duel to be confused, mad). God ea fie maeg tone dolsceadan daeda getwaefan $B$. 479 (only). 
feond-scada

Destructive foe:- Me to grunde teah fah feondscata

B. 554

gud-scada

Noxious, harmful fighter (gudrgen to fight). se gutsceada Geata leode hatode ond hynde B. 23 I8 (only)the dragon.

hearm-scada

Destmuctive foe:- paet waes geocor sid paet se hearm-scada to Heorote ateah B. 766 (only).

leod-scata

Destroyer of the people:- ic dam leod-sceatan yfla gehwylces ( $h$ ) ond-lean forgeald B. 2093. manscada

Ciminal enemy (T. mi, mai to change or falsify; maina, evil, falseness). In Beowulf:- se manscada manna eynnes 7I2; again 737; mihtig manscata wolde hyre maeg wrecan I339 (Grendel's mother); gif mese man-sceada of eort-sele ut gesecet 25I4- the aragon.

syscata

One who offends against the right. In Beowulf:hie ne-moste. . . se syn-scada under sceadu bregaan 707; pone syn-scadass . . . gudbilla nan gretan dorste $80 I$. 
đeod-scada

one molesting, or injuring, the people. In Beowulf:- Swa se deod-sceada preo-hund wintra heold on hru zan hord-aerna sum 2278; pa waes peodsceada pridan side, frecne fy $r$-draca, faenda gemyrdig 2688 .

uht-scada

One who does evil before daylight. Hord wynne fond eald uht-sceada B. 227 I (onlyl.

untyder

An evil race (T. tu to injure):- panon untydras ealle onwocon, eotenas ond ylfe and orcneas, swylce gigantas B.III (only).

waeg-bora

Wave-bearer, a creature that lives beneath the waves:- on naes togen wundorlic waegbora B. I440 (one of the "wyrmes and wildeor" of I430). The word appears only in Beowulf.

wiht

Creature,thing: anything (in negative sentences). Grimm: I "Der sinnfist: arme, krumme geschöpfe, so dass wiht (abuleiten von wiham facere, creare) uberhaupt gleichbedentend mit wesen, creatur, persona erscheint, und auf menschen oder geister gehen kann".

(I) Deutsche Mythologie V.I p. 364 
In Beowulf:- wint unhaelo grim ond graedig I20Grendel; aer hie đaer gesegan syllicran wilt 3038 (Wyrm on wonge 3039); sibb aefre ne-maeg wiht onvendan 260I; no hine wiht dweled; no ic wiht from de swylcra searo-nida secgan hyede 58I; a use similar to these last three is found in 2854, $54 I, 862, I 083, I 660,2348,285 I, I 86, I 5 I 4$, I99 I, I995, 2277, 2464, 2687, 2923.

For the sake of clearness, it scems best to set down the results of the foregoing in the barest manner possible. Thus:

Of the eight animals in the first group, six get only one mention, and that of the slightest.

There are five terms for bird but two of those should, properly, be counted out. Thru the phrase fugle gelicost, it is the ship, not the bird, which is visurized. Then, as we have seen, the wod genet appears only in the evidently poetical phrase ganotes baed.

In the third groupe, the words all denote malevolent beings; the concrete element is comparatively negligible. There are six variations for the word draca, all of which, except one, serve as names for the one fire-drake; these compounds contribute to the concreteness by dwelling on the 
fact that the dragon dwelt in the earth and spewed forth fire when angered. Of the eighteen words in the whole grou $p$, twelve occur only once, and only four of these are accompanied by any descriptive details which would call up a clear picture. Scanning the fourth group reveals that there are forty-eight terms here, but that all but eight of these are descriptive terms applied to one of the three chief monsters of the poem, Grendel, his mother, or the fire-drake. Out of this last I have selected those words which seem to me comparatively concrete, and submit them here, placing the more concrete ones first:

lyft-floga, wid-floga, gud-floga, waeg-bora, angenga, sceadu-genga, mearc-stapa, grund-wiergen, heoru-wearh, muđ-bana, manfardaedla, bana, daed-fruma, giest waelgiest, scada with its compounds, ator-scada and uht-scada. have mentioned these three last, because I wanted to state in connection with them that after all scada does not seem much more concrete than feond, and that out of the ten variations of the word, only the two above named seem to add to the concreteness).

Seymour ${ }^{1}$ devotes a chapter to the animals, fishes, birds and insects in Homer. To quote only a part of his discussion, he says, "The domesticated animals and fowl of which Homer speaks are the horse, the ass (once), mules, the dog, kine, sheep, goats, swine, and geose. The horse is mentioned more than 450 times, lions 62 times. Of 
wild animals, Horer mentions lions, leopards, wolves, jackals, wild boars, wild goats, deer, and hares....... Of birds, the poet names the eagle, the osprey, the falcon, the goshawk, the vulture, the gull, the crane, the swan, the heron, the diver, the halcyon, the wild goose, the crow, the jackdaw, the starling, the nightingale, the thrush, the sparrow, the swallow, and the pigeon".

To point out that Beowulf is much shorter than either the Iliad or the Odyssey, or to suggest that animals were not numerous in this far northern country seems to me beside the point. The Beowulf poet did not reject the mention of animal life or bird life because of lack of space, or through ignorance of such life, but because his interest was not in the concrete. That the people of the world here portrayed were interested in and acquainted with animal life, the art remains bear witness. Muller in his I'Europe.

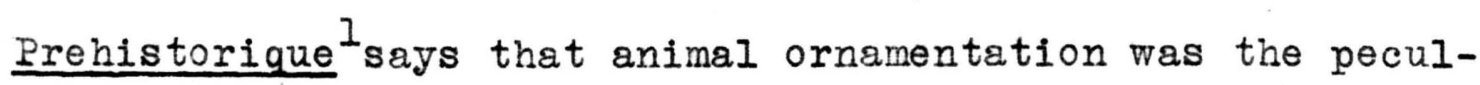
iar mark of the early art of the North. It is not so remarkable that few concretes of this sort find a place in the old A poem --- indeed, the list is fairly long -- as that the mention of them is so slight and so incidental to 
something else that one has to re-read the poem carefully to discover that a dog or a hart or a hawk has been named at al1.

of Grendel we are told that he had a long arm with claws; this appears in the first account. In the second nar ation of the same event a pouch shich he wore, fastened with curious clasps, is mentioned. Once he is called eoton, which may be interpreted giant man-eater. Beyond this, the poet delights to designate this adversary of Beowulf as "Ione-goer","destructive foe", "the mighty spirit who dwelt in darkmess", "the death-shadow". He is the more awful that one cannot draw from the poem a full picture of him.

of the dragon is the picture more complete.

Still a comparisoon of the concrete and abstract elements in the story of the dragon fight is worth considering. All the details have been given in the foregoing lists, but I re-arrange them here, giving them in the order in which they ctually appear in the story and placing first the objective details relating to appearance and action and second those which refer to the mood or nature of the monster.

(a) He watched over a hord, he was old, he was naked, wrapped in flames, he flew by night, he was old in winters, three hundred winters old, he sniffed the rock, he was glowing, furnished with fire, vomiting live 
coals, he surrounded the land folk with fire and wasted the land, he was venomous, had a hot breath, he cólied together and advanced twisting, he threw out a murderous fire and his breast heaved with breathing, he belched forth bright fire; he enclosed Beowulf's neck between his cutting jaws.

(b) His ire was aroused, he was a grisly horror, he was vengeful, enraged in heart, he was valiant-hearted, fierce at heart, he had gleeful thoughts of fighting, he was impatient, bursting with rage, he was loathly, a gruesome stranger, his heart impelled him to seek the contest, he was mad in spirit, was a fell spiteful spirit, he was a vengeful stranger. 


\section{The Iand, The Sea, And The Sky}

The heading is here stretched to cover words denoting 1) places, 2) details of landscape, 3) the sea, 4) the sky and light. To the terms for lights of the sky I have added names for fire, as it seemed that these should be mentioned.

\section{I}

be gang

Course, way:- under swegles begang B. 860, 1773; ofer floda begang B. 362, 1826.

ede1

Fatherland, ancestral seat, land, home (T ap ala nature, kina; 아 ala inheritance). In Beowulf: đonon he gesohte swasne eđel 520; haelepa rice, edel Scyldinga 913; wisdome heold eđel sinne 1960; seled him on eple eorpan wynne 1730; if also 1774. fresten

1) The firmanent: e.g. roderas faesten Gen. 148;

2) any guarded place: the prison in An. 1036, the grave in sat. 521; 3) stronghold, fortress. In Beowulf:- se-pe moras heold, fen and faesten 104; Haefae lig-draca leoda faesten ea-lona utan eordweard to ne gledum forgriknden 2333; Gewat him da 
se goda .... faesten secean 2950 .

feorcyd

Remote land, country of aliens:- cyđd kun $p i p 0$. OHG. cundida race, kinship; an abstract formation). In Beowulf (only): feor-cy pde beod selran gesohte paem pe him selfa deah 1838.

folc-scare

ivation, province, division of the people, folk-land:eall gedaelan geongum ond ealdum swylc him god sealde buton folc-scare B. 73. Klaeber ${ }^{l}$ and Holtthausen ${ }^{2}$ both translate the word, as found here in Beowulf, 'land'.

fold

The earth, the firm land. In Beowulf: gefraetwade foldan sceatos leomum ond leafum 96; Đa waes winter scacen faeger foldan bearm 1137; healobeaga maest para- pelic on foldan gefraegen habbe 1196; flod under foldan 1361; cf. also 1393, 2975.

geard

Dwelling-place ( $I$. gerd, to girdle, hedge in). In Beowulf:- nodaes frod leofad gumena bearna paet pone grund wite 1367 (the "dygel land" where Grendel

1. Mod. Phil. 3, p 447 .

2. Anglia Bei. 4, p 34 . 
dwelt); on gyfenes grund 1394; under gynne grund 1551; me to grunde teah 553; Hord-weard sohte georne aefter grunde 2294; gold glitinian grunde getenge 2758; gold on grunde 2765; Iastas waeron ....... wide gesyne, gang ofer grundas 1404; Sydđan heofones gim glad ofer grundas 2074.

eormen-grund

Terra immensa, the wide world:- ofer eormen-grund be saem tweonum 859 (only).

mere-grund

Bottom of the mere. In Beowulf (only):- he hean donan modes geomor mere-grund gefeoll 2100; se pe mere-grundas mengan scolde, secan sund-gebland 1449. sae-grund

Sea-bottom: paet hie me pegon symbel ymbsaeton sae-grunde neah B. 564.

hruse

Earth (T. hrus to become hard, rough; hruson crust). In Beowulf:- Heold pu nu, hruse, nu haeled nemoston eorla aehte 2247; hruse dynede 2558; He gesecan sceall hord on hrusan 2276; hlaew under hrusan hohnewylme neh 24ll; he on hrusan ne-feol faeger fold-bold 772; se wid-floga .... hreas on hrusan 2831 .

land

Iand. In Beowulf:- Him waes bam samod on dam leodscipe land gecynde, eard eđel-riht 2197; fret da 
lidende land gesawon 221; pe on land Dena lađra naenig mid scip-herge scedpan ne-meahte 242; on Finna land 580; con him land geare 2062; Hie dygel land warigead, walf-hleodu 1357. These citations illustrate the loose use of the word; it occurs 19 times in Beowulf.

rice

Kingdom (T. rika, rikia mighty, sbst. ruler; rikia power, rule, kingdom); an abstract word. In Beowulf:- Monig oft gesaet rice to rune 172; side rice 2199; Syddan Beowulfe brade rice on hand gehwearf 2207; haele pa rice edel scyldinga 912; folc ond rice 1179; gyf $p u$ healdan wylt maga rice 1853 ; cf. also $2369,3004,861,1390,1859,2027$, 3080 .

sceat

1) Angle, projecting corner; 2) part of the earth, region (T. skut to shoot out, project). In Beowulf:- (he) gefraetwade foldan sceatas leomum ond leafum 96; he ne-mette middan-geardes eor $p$ an sceatta on el a ran men mundgripe maran 752 .

stede

Place. Given asthe reading in 985 by Thorpe, whereas Sievers gives stidra.

baelstede

To be given under Disposal of the Dead. burh-stede

Place of the citadel, state. In Beowulf:ne se swifta mearh burh-stede beated 2265 . 
folc-stede

Dwelling place, earth, city, fortress:- eall paet mearc-land,folc-stede gumena An. 20. In Beowulf: weorc gebannan ... folc-stede fraetwan 76---Heorot; se-đe gryre-sidas gegan dorste, folostede fara 1462.

heah-s tede

High place. In Beowulf: paer wunad on heahstede husa selest 285 (only).

medel-stede

Place of assembly, for discourse. (Battlefield in By. 199, An. 658, 697). In Beowulf: he ne-pehte

on paem medel-stede wig Hengeste wiht gefeohtan 1082 .

wic-stede

Dwelling-place. In Beowulf: Gemunde da da are pe he him aer afgeaf wic-stede weligne Waegrandings 2607; puhte him eall to rum wongas ond wicstede 2462 .

wong-s tede

Flat place, place: in dam wong-stede B. 2786 - place of the fight with the dragon.

stow

Place. In Beowulf: nis paet heoru stow 1372 the mere; Eard git ne - const, frecne stow, faer $p u$ findan miht (fela) sinnigne secg 1378; grundbuendra gearwe stowe 1006 - the place where the soul is to 
go.

wael-stow

Battle-field:- paer hyne Dene slogon, weoldon wael-stowe B. 205l; yaet his wael-stowe wealdan moston 2984 .

II

As preface to this section one might quote those lines from the description fo the haunted mere, which contain seven words not found elsewhere in Ag. poetry:

\begin{tabular}{|c|c|c|}
\hline Ofereode pa & ae pelinga bearn & I. 1408 . \\
\hline steap stan-hlido & $\cdots \cdots \cdots \cdots \cdots \cdots \cdots \cdots$ & \\
\hline enge anpadas & uncud gelad & \\
\hline$\cdots \cdots \cdots \cdots \cdots$ & $\bullet \ldots \ldots \ldots \ldots \ldots$ & \\
\hline$\ldots$ & nicor.husa..fela & \\
\hline op - paet he faeringa & fyrgenbeamas & I. 1414. \\
\hline ofer harne stan & hleonion funde.. & \\
\hline gesawon da aefter watere & $\cdots \ldots \ldots \ldots \ldots \ldots$ & \\
\hline$\bullet \cdots \cdots \cdots \cdots \cdots \cdots \cdots$ & $\bullet \cdots \cdots \cdots \cdots \cdots \cdots$ & \\
\hline swylce on naes-hleodum & nicras licgean & \\
\hline đa on undern-mael & oft bewitigad & \\
\hline sorh-fulne sid & on segl-rade & \\
\hline
\end{tabular}

anpaed

Solitary path: enge an-padas B. 1410 beam,appearing in Beowulf only in the cp. fyrgen-beam.) 
fyrgen-beam

Mountain tree (T. ferhu oak; fergunja mountain. -Forest-covered mountain?) In Beowalf (only);

op paet he faeringa fyrgen-beamas ofer harne stan hleonian funde 1414 .

bearu

Forest: paet se mere standed ofer paem hongiad hrinde bearwas 1363 .

beorg

1. Mountain or hill (T. bergh to be high). B. 3164, 2241, 2299, 2304, 2322, 2524, 2580, $2755,3066,211,2546,2559,2842,3143,2272$, (according to Grein)

2. Burial mound, "tumultus":- in B. 2241, 2304, 2322, 2324, 2559, 2842, 2299, 3097, 3163, 2807, 2272 .

(according to Sedgefield)

In illustration:

Flota waes on youm bat under beorge B. 2II; on beorge baelfyra maest 3143; land gesew on brfm-clifu blic an beorgas steape 222.

stan-beorg

Rocky hill:- se-de on heaure haepe hord beweotode, stan-beorh steapne B. 2213. 
clif

Cliff, height:- paet hie Geata clifu ongitan meahton cu pe naessas B. 1911.

brim-clif

Cliff on the sea:- Heht da paet heado-weore to hagan biodan up ofer e (c) g-clif B. 2893 (only). hohn-clif

Sea-cliff, promontory. In Beowulf only:- syd $p$ an Aescheres on pam holm-clife hafelan metton 1421; from paem holm-clife hafelan baeron 1635 - Grendel's head; fa of wealle geseah weard scildinga se-pe holm-clifu healdan scolde 230.

stan-clif

Stony cliff, projecting rock:- hioro-sercean baer under stan-cleofu B. 2540 (down to dragon's hord). weall-clif

, cliff, cliff of the shore:- dracan ec scufun, wyrm ofer weall-clif B. 3132 (only)

ea-land

Island, land on the sea

In Beowulf;- Haefde lig-draca leoda faesten ealand utan......gledum forgrunden 2334.

fenn

Swamp. In Beowulf:- se- pe moras heold fen oud faesten 104; pa heo to fenne gang 1295. 
fen-freodo

Asylum in the swamp (fridu love, peace).

siddan dreama leas in fen-freoto feorb alegde $B$. 851 (only).

fen-gelad

Path in the swamp or moor:- Hie dygel lond warigead ...... frecne fen-gelad B. 1359 (only).

fen-hlid

Bank of the moor, hill in the moor:- feorh-seoc fleon under fen-hleođu B. 820 (only).

feor-weg

Far away: paer waes mađma fela of feor-wegum fraetwa gelaeded B. 37 .

haep

An uncultivated field, desert place:- on heaure hae $p e$ B. 2212. (Grundtvig). A mutilated part of the manuscript.

hlid

Slope, side of a mountain (T. hli to lean). In Beowulf:- no he mid hearme of hlides nosan gaestas grette 1892; Geworhton da Wedera leode hlaew on (h) lide 157 .

fen-hlid

See under fen.

mist-hlid

Misty slope:- Đa com of more under mist-hleop um Grendel gongan B. 710 . 
naes-hlid

Slope of the promontory: swylce on naes-hleodum nicras licgean B. 1427 (only).

stan-hlid

Rocky slope:- ofer-eode $p a$ ae pelinga bearn steap stan-hlid B. 1409 .

wulf-hlid

Slope infested by wolves:- Hie dygel lond warigead, wulf-hleođu, windige naessas B. 1358 (only).

holt

Wood, "silva!:- hy on holt bugon B. 2598; da hildlatan holt of-gefan 2846; in Hrefues-holt 2935. fyrgen-holt

Mountain wood: Ic hit pe gehate: nolhe on holm losap....ne on fyrgen-holt B. 1393 (only). hop

According to $\mathrm{Gr}$. "recessus, was in die Bedeutung von Bucht, Heer Übergeht .. Da das engl. hoop ... überhaupt jeder ringförmige oder ans Reifen bestehende gegenstand, Reifrock, Hühnerkorb .. sowie engl. to hoop mit Reifen umgeben, einfaszen, nicht füglich davon getrennt werden kann, so durfte wohl auch in hop zunachst die Bedeutung des Ringformigen zu suchen sein und die fenhopu, norhopu, des Beowulf; liedes waren die runden tiefen Waszer-tumpel inmitten der Sumpf-oder Moorflachen". The word appears in Beowulf only in compounds. 
fen-hop

Oozy, moist swamp (palus uliginosa); fen-heap or mound, B. T. says. Sarrazin'says, "Der hop ist ei ne hesondere art teich; nach Egilssons definition im Lexic. Poet. Septentr. hop: lacus vivus in mare propinquum se exonerans, aut per quem fluvius prope a litore mari influit quique accessu aestus marini restagnat". In Beowulf(only): and on weg panon fleon on fen-hopu 764 .

morhop

Moor cove, a bay or creek in the moor (moores-bucht), according to Grein; B. T. says, "a pool in a marsh" See Sarcazin's explanation under fen-hop. In Beowalf (only):- mearcad morhopu 450 (only).

leaf

Ieaf, follage:- gefraetwade foldan sceatas leomum ond leafum B. 97 - in an account of the creation. naes

Headland, promontory, ness. In Beowulf:- on naes togen wundorlic waeg-bora 1439; Naes ofgeafon hwate Scyldinga 1600 (on the bank of the haunted mere); Iyt swigode niwra spella se-đe naes gerad 2898; under Earna-naes 3031; (beorh) waeter-yđum neah niwe be naesse 2243; Hronesnaesse 2805 and also 3136 ; under naessa genipu 1360.

1. "Schauplatz des Ersten Beowulfiledes," Beitrage XI, p 162 . 
Promontory. In Beowulf (only):- brim-clifu blican beorgas staepe, side sae-naessas 223; ic sae-naessas geseon mihte, windige weallas 571. nicor-hus

House of sea-monsters. Sarrazin mentions "In der nahe hügel die als nixenwohen bezeichnet werden." In Beowulf only:- neowle neessas, nicor-husa fela 1411 .

nose

Promontory (From the low ablaut grade of nas nose). In Beowulf:- no he mid hearme of hlides nosan gaestas grette 1892; aet brines nosan 2803 .

sand

Sand. In Beowulf: streamas wundon, sund wid sande 213; nacan on sande 295; similarly 1896, 1917; mid his hand-scole sylf aefter sande sae-wong tredan 1964; Fundon da on sande sawul-leasne 30.33. stanboga

Stony arch. In Beowulf (only):- Geseah da be wealle ... sto $(n)$ dan stan-bogan 25.5 ; seah .. hu đa stanbogan stapulum faeste ece eord-reced innan heolde 2718 .

wang

Elain, field; B. T. says,"The word, which is almost confined to poetry, may be rendered by words denoting the surface of the ground taken in their most general sense field, plain, land, country, place." 
The word is included here because its compounds give it a somewhat special sense.

In Beowulf: he feara sum beforan gengde wisra monna wong sceawian 1413; wong wisian 2409; se almihtiga eordan worhte, wite-beorhtne wang swa waeter bebuged 93; Wedera leode on wang stigon (landed) 225; puhte him eall to rum wongas ond wic-stede 2462; cf. 3073 also.

fri đu-wong

Plain of peace or peaceful plain:- pa waes aeht boden Sweona leodum, segn Higelace: freodo-wong pone ford ofer-eodon sydđan Hredlingas to hagan prungon B. 2959 (only).

grund-wong

Bottom. In Beowilf (only): brim-wylm onfeng hilde-rince. Đa waes hwildaeges aer he pone grundwong ongytan mehte 1496; Me-waes paet ede sid paet se maera maga Ecgđeowes grund-wong pone ofgyfan wolde 2588 ; cf. also 2770.

meodo-wong

Mead plain, plain around the mead-hill. In Beowulf: gum-drybten mid modig on gemonge meodo-wongas traed 1643 (only).

sae-wong

Sea-shore, plain by the sea. In Beowulf: (se hearda) mid his hond-scole sylf aefter sande sae-wong tredan B. 1964 (only). 
warod

Sea-shore (T. Varu>a raised land, protected against flood). In Beowulf:- Gewat him fa to warode wicg ridan fegn Hrodgares 235; sae-wong tredan wide warodas 19651965 (aefter sande 1964).

weall

Wall: wealle beworhton 3161 (a description of the building of the barrowl.

eord-weall

Sea-wall or rampart:- Higelac Hrepling faer aet ham wunade selfa mid gesidum sae-wealle neah B. 1924 . westenn

Desert, waste, solitude. In Beowulf:- (the drake) hlaew oft ymbe-hwearf ealne utan-weardne; naes daer aenig mon on faere westenne 2298. $y a^{-1}-1$ af

Remains of waves, shore. In Beowulf: ac on mergenne mecum wande be yd-lafe uppe laegon 566 .

\section{III}

Of names for bodies of water, Mr. Lawrence says" "Sae holm, mere, sund, brim, maybe used of inland water, (as well) as of the sea)...... The stream which gushed out of the rock at the commend of $\mathrm{St}$. Andrew is called mere-flod (1526),

1. "The Haunted Mere in Beowulf", Pub. Mod. Iang. Assoc. Vol. 27, p 218 . 
sund (1528), geofon (1531), firgend-stream (1573), and brim $(1574)^{\prime \prime}$

brim

Woving water, sea (Grein evidently regards the word as coming from the prim. Germanic root brem to move unsteadily; Torp derives it from brem to roar, to make a noise. Brim oft oncwaed, yd oderre An. 442; brim berstende Exod. 477. In Beowulf: Đaer walo on blode brim weallende atol yá geswing eal gemenged 847 (on nicera mere 845); faet waes yd geblond eal gemenged, brim blode fah 1594; to brimes farode 28; aet brimes nosan 2803; beorht beacen godes brimu swadredon 570 .

farod

Fluctuation of the sea, sea (T. fer to go). In Beowulf: Hi hyne pa aetbaeron to brimes farode 28; Đa mec sae opbaer flod aefter farode on Finna land 580; se pe aer lange tid leofra manna fus aet farode feor wlatode 1916.

flod

Flood, current. By. 65 uses the word when speaking of the ebb and flow of the sea-tides; An. $956 \mathrm{em}-$ ploys it in connection with blood flowing in strearns. In Beowalf: op daet une flod todraf wado weallende 545; Đa mec sae opbaer flod aefter farode 580; under naessa genicu, nider gewited flod under 
foldan 1361; Flod blode weol 1422; sydfan flod ofsloh giganta cyn 1689; ofer fealone flod 1950; weg niman,flod faedmiam fraetwa hyrde 3133; on flodes aeht feor gewitan 42; faergripe flodes 1516; fyres feng odde flodes wylm 1764; nid-wundor seon, fyr on flode 1366; Cwom pa to flode fela-modigra haeg-stealdra (heap) 1888; se-de floda begang heoro-gifre beheold 1497; ofer floda begang 1826; ofer floda genipu 2808.

ford

ford, water-way. In Beowulf: syd $p$ an na ymb brontne ford brim-lidende lade ne-letton 568 . garsecgt

Ocean (etymology not clear). In Beowulf:- leton holm beran geafon on gar-secg 49 (on flodes aeht 42, ofer yđe 46); maeton mere-straeta... glidon ofer gar-secg 515; wit on gar-secg ut aldrum neđdon 537 .

B. T. says, "The myth of an armed man, a spear-man is employed by the Anglo Saxon as a term to denote the ocean and has some analogy to the personification of Neptune holding his trident". sund-gebland

Commingling of waves (T. blend, to mingle). In Beowulf (only): se-de mere-grundas mengan scolde, secan sund-gebland 1450 . 
yđ-gebland

Mingling of waves, flux; the tossing waves. In Beowlif (only): ponon yd-geblond up astiged won to wolcnum 1373; paet waes y-gebland eal gemenged, brim blode fah 1593; waeron yd-gebland eal gefaelsod 1620.

geofon

Sea, something flowing. In Beowulf: geofon ypum weol 515; syatpan flod ofsloh gifen geotende 1690; Her syndon geferede feorran-cumene ofer geofenes begang 362; Ic hit pe gehate: no he on holm losa... ....... ne on gyfenes grund 1394.

haef

Sea (T. hafjan to left; haba the sea). In Beowulf (only): Ongenđeowes eaferan ........ freode newolden ofer heafo healdan 2477 .

holm

1) Originally a rounded height, on island; 2) Highrising sea waves; 36 sea, water. In Beowulf: hine on morgen-tid ..... holm up aetbaer 519; holm storme weol 1131; holm heolfre weoll 2138; leton holm beran, geafon on gar-secg 48; ic on holm gestah sae-bat gesaet 632; no he on holm losad 1392; on holm wliton paet waes yđ́-geblond eal gemenged 1592; no he wiht from me flod-yđum feor fleotan meahte hrador on holme 543; he on holme 
waes sundes pe saenra 1435; Hrape waes aet holme hyd-weard gearu 1914; he to holme stag 2362; brontre ceol ofer lagu-straete laedan cwomon hider ofer holmas 240; cf also 2132.

waegholm

Deep sea; B. T. says, the billowy sea. In Beowulf: Gewat pa ofer waeg-holm winde gefysed flota fami-heals 217 (only).

lad

Way, path. In Beowulf: paet syd pan na....... ... brim-lidende lade ne-latton 569; Hu lomp eow on lade, leofa Beowulf, 1987.

brim-lad

Way or path of the sea. In Beowulf: para-pe mid Beowulfe brim-1(e)ade teah 1051.

sae-lad

Sea way. In Beowulf: he to gyrn-wrace swid or pohte ponne to sae-lade 1139.

$y đ-1 a d$

Sea way. In Beowulf (only): gode poncodon, paes pe him yd-lade eade wurảon 228 .

lagu

Lake, Sea, water (T. Iagu Nasz, "wetness"). lagu land gefeol Exod. 4820. In Beowulf:- lagu drusade waeter under wolcnum, wael-dreore fag 1630. 
mere

Sea, lake, pool; B. T. gives as the first meaning: sea, second mere or lake, third an artificial rool or cistern. In Beowalf: se mere standed ofer đaem hangiad hrinde bearwes (the haunted mere) 1362; on nicera mere 845; he (ne)-meahte on mere arifan hringed stefna; holm storme weol 1130; Gistas setan modes seoce ond on mere staredon 1603; from mere modge mearum ridan 855 .

rad

1) Riding; 2) way, road. The word appears only in cp. in Beowulf.

hran - rad

Whale-road, sea. In Beowulf: aeghwylc (para) ymbsittendra ofer hron-rade hyran scolde 10. segl-rad

Course or way of a sail, sea:- oft bewitigad sorhfulne sid on segl-rade wyrmas ond wildeor B. 1429(only). swanrad

Road of swans, the sea:- he, gud-cyning ofer swanrade secean wolde $B \cdot 200$.

sae

Iake, sea (T. sih to filter through, fall in arops; saivi sea). In Beowulf: mec sae op baer flod aefter farode 579; swa sae bebuged windge (e)ardweallas 1223; on sidne sae ymb sund flite 507; 
Wraec-maecgas ofer sae sohtan suna otheres 2380;

cf. also 2394, 318; be saem tweonum 858, 1297, 1685, 1956; wit aetsomme on sae waeron fif nihta fyrst 544. seolod

Bay, sea. In Beowulf (only): oferswam pa sioleda bigong eft to leodum 2367

Bugge makes this conjecture in regard to this passage: "Sioled mid kurzem vokale kann zum got. anasilan still werden (vom winde) gehoren, $\mathrm{vgl}$. schwed. dial. sil n. stilles gewasser (wwischen wasserfallen) in einem flusse. sioleda bigong wurde demnach das ruhige meer bezeichnen, was in diesem zusemmen-hange nicht un-passend scheint."

Schucking in his glossary says, "sioleda bigong den Bereich der Buchten -- das meer."

straet

Plat way or street: fealwe straete mearum maeton 916; cf. also 320 and 1634. In these three passages the word has the usual maning 'street', to be mentioned later.

lagu-straet

Way or path of the sea. In Beowulf (only): brontne ceol ofer lagu-straete laedan cwomon 239.

mere-straet

Sea-way, the road which the sea furnishes:- git eagor-stream earmum pehton maeton mere-straeta B.514. 
stream

Flowing of water, flood, river, torrent, sea. In Beowulf: stream ut ponan brecan of beorge 2545; streamas wundon sund wid sande 212; se-pe waeteregesan wunian scolde cealde streamas 1261.

brim-stream

Sea flood. In Beowulf: fleat famig-heals ford ofer yde bunden-stefna ofer brim-streamas 1911. eagor-stream

Current of water, sea. In Beowilf: paet git eagor-stream earmum pehton maeton mere-straeta 513 . fyrgen-stream

Mountain stream. In Beowalf (only): đaer fyrgenstream under naessa genipu ni $>$ er gewited 1359; hio paet lic aetbaer feondes faedmum under firgenstream 2128.

lagu-s tream

Fluctuation of the waters; (according to B. T.) sea, stream, river, water:- ofer lagustreamas (waters of the deluge)Exod. 367; folde and lagustream, earth and sea Met. 11, 43. In Beowulf:- op - paet eft byred ofer lagu-streamas leofne mannan wudu wundenhak 297.

sund

1) Swimming, 2) the ability to swim, of the sea, the narrow sea between two lands. In Beowulf: he on holme waes sumdes pe saenra 1436; se de on sunde oferflat 517; sona he waes on sunde ... waeter up purhdeaf 1618; streamas wundon, sund wid sande 213 ; pa 
waes sund liden 223; ymb sund flite 507; similarly 512, 539; sellice sae-aracan sund cunnian 1426; similarly 1444; meaning swimming 1510.

waed

Ford, shallow water, sea; B. T. says that the word is used only in poetry to mean the sea; in prose it has its first meaning. In Beowulf:- unc flod to-draf, wado weallende B. 546; đaer mec sae odbaer on Finna land, wadu weallendu 581, đaer git for wlence wada cunnedon 508 .

waeg

Fluctuation, wave (T. vago movement). Waeges weard An. 632; faran ofer wega gewinn An. 943. In Beowalf: leton weg niman flod faedmian fraetwa hyrde B. 3132 .

waeter

Water (vet to well forth). In Beowulf: se aelmihtig eordan worhte wlite-beorhtne wang swa waeter bebuged 93; waeter under stod dreorig ond gedrefed 1416; him naenig waeter wihte ne-scedede 1514; lagu drusade, waeter under wolcnum 1631; on deop waeter aldrum ne don 509; ofer sealt waeter 1989; ofer wid waeter 2473; he hine eft ongon waeteres weorpan 2791; similarly 2854; cf. also 471,516,1693,1425,1656,2722.

wylm

surging, flowing. There are numerous compounds, but those which follow are the only ones denoting the surging of the sea. 
brim-w $w_{\mathrm{y}}$

Surging of the sea. In Beowulf (only);
brim-wylm on-fing hilde-rince 1494 .

holm-Wylm

Billowing or tossing of the sea. In Beowulf (only); sae-wylm

Tholmwylme neh, yđ-gewinne B. 2411 .

Undulating, tossing of the sea, a billow. In

Beowalf (only); ge him synaon ofer sae-wylmas heardhicgende hider wil-cuman 393.

zd

Wave in Beowulf: hreo waeron yda. 548; ofer yta gewealc 464; atol yde geswinge 848 (on blode brim weallende 847); Ofer yta ful 1208; under yta gewin 1469; y $p$ a Prym 1918; flota waes on ytum weoll 515; having the general meaning of sea 421, 1437; 534; 46, 7909; 1132 . flod-yd

Wave of the sea. In Beowulf (only): No he wiht from flod-yp um feor fleotan meohte 542 .

waeter-yđ

Wave of the sea: waeter-ytum neah niwe be naesse

B. $2242(\mathrm{onl} j)$.

yđ-gewinn

Tumult of waves (T. Ven to struggle). Sumne Geata leod of flan-bogan feores getweefde yd-gewinnes B. 1434; hlaew under hrusan holm-wylme neh yd-gewinne 24I2. (In Beorralf only). 


\section{W.}

beacen

Signal, sign, portent, miracle. The word stands for the cross in El. 92. In Beowulf: beorht beacen godes 570--the sun; segn eac genom beacne beorhtest 2777--a banner found in the dragon's hoard; beadiz-rofes been 3160--the grave-mound. I Include this word in the list because of its use in 1. 570 as a metaphor for the sun.

candel and worold-candel

Candle, the sun, the light of the world. In Beowulf: hadre scined rodores candel 1572; world-candel scan, sigel sudan fus 1965. ( The second word occurs only in Beowulf).

fygr

Fire. In Beowulf:- fys on flode 1366--on the haunted mere; sawle bescufan in fyres feng 185 (of hell); eft sona bid paet dec adl adde ecg eafopes getwaefed odde fyres feng 1764; the fire belched forth by the dragon and wrapping him as he flies 2701, 288, 2274, 2209, 2595.

heado-fyr

Fire used in fighting, (by the dragon).

ic daer headu-fyres hates wene B. 2522; waes paere burnan waelm heado-fyrum hat 2547. (The word gled is found only in Beowulf).

gled 
gled

Fire, glowing coal, flame (T. glo to glow; glodi fire, a glowing coal). In Beowulf: faet minne lichaman mid minne gold-gyfan gled faedmie 2652; nu scealgled fretan 3114 (weaxan wonna leg); Đa se gaest ongan gledum spiwan 2312; lig-draca leoda faesten ......eord-weard done gledum forgrunden 2335; cf. also 2677, 3041.

heofon

Sky. In Beowulf:- heofon rice swealg 3155; no id on niht gefraegn under heofones hwealf heardran feohtan 576; similarly 2015; oppaet hrefn blaca heofones wynne blid-heort bodode 180; hoofones gim 2072; under heofenes hador 414; efne swa of hefene hadre scined rodores candel 15171; hie huru heofena helm herian ne-cup on daeda demend 1812; conventional use 505 and 52.

leg or lig

Flame. ( T. (luh) to light). In Beowulf,- Iig ealle forswealg 1122 (wael-fyra maest 1119); nu sceal gled fretan (weasan wonna leg 3115; swogende leg wope bewunden 3145; heađo-wylma bad ladan liges 83; nympe liges faem swulge on swa $p$ ule 781; liges 83; him of eagum stod ligge gelicost lioht 
unfaeger 727; wolde se lada lige forgyldan drinefaet dyre 2305; Haefde land-wara lige befangen 2321; helpan ne-meahte lind wid lige 2341; dracan lege 2549 ( heady-fyrum hat 2547).

Leoht

Light. In Beofulf: leoht eastan com beorht beacen godes567; him of eagum stod ligge gelicost leoht unfaeger 727; Lixte se leoma leoht inne stod efne swa of hefene hadre scined rodores candel 1570; suminan leoht 648; gum-aream ofgeaf, godes leoht faergeceas 2469; sunnan and monan leoman to leohte 9.

aefen-leoht

Evening light. In Beowulf (only): sidđan aefen-leoht under heofenes hador beholen weor $p$ ed $\mathbf{4 1 3}$. fyr-leoht

Pire-light. In Beowulf (only); fyr-leoht geseah blacne leoman beorhte scinan 1516 (in the den of Grendel's mother).

morgen-leoht

Morning light. In Beowulf (only); sippan morgen-leoht ofer ylda bearn op res dogores sunne swegl-wered supan scined 604; Đa waes morgen-leoht scofen and scynded917.

leoma

Light, splendor; leomena leas (blind) Vy 17. 
In Beowulf: lixte se leoma, ofer landa fela (the light from gold adorned Heorot311; Lixte se leoma leoht inne stod 1570), (In the den of Grendel's mother); of dam leoma (an) stod paet he pone grund-wong ongitan meahte 2769 ; of, also 95, 1517 . aeled-leoma

Torch, shining fire. In Beowulf (only); Sun on hande baer aeled-leoman, se-de on orde geong 3125. mona

Hoon. In Beowulf: gesette sige-hrepig sunnan and monan leoman to leohte land-buendum 94. sigel

Sun (also the name of the runic letter $S$ ). In Beowulf: Woruld-candel scan sigel sudan fus 1966. sunne

Sun. In Beowulf: sunne swegl-wered sup an scined 60; gesette sige-hrepig sunnan ond monan 94; sidđan hie sunnan leoht geseon (ne)-meahton $\underline{648}$.

swegel

Ether, sky (used to mean the sun in $\mathrm{Ph}$. 212, to mean symphony or melody (n. 871). In Beowulf: under swigles begong 860; similarly 1773; under swegle 1078; similarly 1197 .

wolcen 
wolcen

Cloud, especially common in the adverbial phrase under wolcnum B. 8,651, 714, 1631, 1770. ydgeblond up astiged won to wolenum (B. 1374) has some descriptive value.

roder

Sky, heaven. In Beowulf: rodores candel 1572; roderas reotad 1376; rodera raedend 1555; under roderum 310 .

In comment on the foregoing, it may be said that there are lines in the poem of bold clear concreteness, but the scene of action is lighted up for a brief space only to disappear altogether. for instance, among the forty-four words grouped under $\underline{2}$, twenty -nine occur only once. Indeed, the list, by its length, is misleading, clif, brim-clif, holm-clif, weall-clif, naes-hlid, naes, sae-naes, nose, all call up practically the same image in the mind. Fen-hop and mor-hop are interchangeable terms. We know that there were trees of various kinds and moorland vegetation in this region, but only once is a tree mentioned. of the sea and the seashore with its cliffs, the poet draws stranger, clearer lines than of the interior. 
Still, he has sixteen words which denote the andulation of the sea and six which speak of it as a path, as something to be traversed. No one of the se terms shows a gain in concreteness, in detailed picturing, over the others.

The abode of Grendel and his dam is something quite different from the open sea, but mere, brim, flod, stream, sund, are used of both the ocean and the haunted mere. Iagu is, in Beowulf, restricted to the pool where Grendel dwelt, but Beowulf, in coming to Heorot, sailed "ofer lagu -straete". yd-geblond, sund-geblond, brim-wylm are mentioned only in connection with the mere. Beowrif promises that Grendel shall not escape "on holm" or "on gyfenes grund", as though those were his haunts, However, farod, ford, garsecg, haef, waegholm, brim-dad, saeead, 迆-dad, hran-rad, segl-reed, swan-rad, sae, brimstream, eagor-stream, lagu-stream, waed, clearly denote only the wide sea, which men traverse in ships. of the first and last groups little need be said. The writer evidently has a love for unbounded spaces; only rarely does he sketch in details. He prefers, too, larger abstract terms like light to such words as sun and moon. 
The most natable bit of description in the poem, that of the haunted mere, is such a device as Poe might choose to heighten the sense of the weird and the terrible in the combat which was to take place there. "Nis paet heoru stow", (1372). 
E. "The Index of Things Mentioned In Beowulf."

As already stated, this section is a review of Doctor Clark Hall's study lists entitled Index of Things Mentioned in Beowulf, which he adds as an appendix to his own translation of Beownlf, and to his translation of Stgerna's Essays on Beowalf. Miss Keller's dissertation on Weapon Names in Anglo-Saxon and Mr. Schnepper's on Die Namen der Schiffe und Schiffteile im altenglischen have here served to furnish aditional comment on those parts of Doctor Hall's work treating weapons and shipping.

Generalizations offered in connection with these objects are based on the material offered by the scholars just named, although some independent study of the whole field has served to give a point of view, perhaps.

The section is divided into accounts of:

$$
\begin{aligned}
& \text { 1. The hall. } \\
& \text { 2. Wardress. } \\
& \text { 3. Weapons. } \\
& \text { 4. The Ship; } \\
& \text { 5. Valuables. } \\
& \text { 6. Miscellaneous. }
\end{aligned}
$$




\section{The Hall}

I.

To begin with the centre of the social life, the hall of the lord, we find here, from Dr. Hall's list, terms of three types, the nouns denoting dwelling place, the very general words for building or hall, and the words which usually denote Heorot, the residence of King Hrodgar, and hence seem Iimited to that type of dwelling. Examples of nouns of the first class are wic, ham, geard, hof; of the second class, bold, hus, aern, reced; of the third, heall, sael, sele. One can easily generalize too soon, however. Dr. Hall himself notes an overlapping of terms. Bold (selest) $2326=\underline{h a m}$, fold-bold (faeger) $773=$ win-sele; reced (selest) $412=\underline{\operatorname{sele}}, 770=$ win-sele, win-reced $704=$ gold sele, 993=gest-sele. And I note that Heorot, which is heal-aerna maest 78 is heal-reced 68 , medo-aern 69 , and sele 81; beorhte bold 997-win-reced 993-gest-sele 994; bold waes betlic 1924 -- on hean healle 1926. Certainly, it is not clear whether there was any distinction between reced and heall, for inst ance, or how the variation in names could be construed as ading anything to the concreteness of the idea. Once is a temple mentioned, heargtraef. 
The compoundsfor hall seem formed to satisfy the poet's desire for variety or to meet the exigencies of alliteration. They suggest the activities of the purpose of the hall rather than ita appearance. In any case many of them fall together: medo-aern, winaern, win-reced, medo-heall, medu-seld, beor-sele, win-sele, -- the banqueting hall; gif-heall, beah-sele gold-sele, hring-sele, the hall of the lord, who there dispenses gifts; đryd-aern, dryht-sele, perhaps gud-sele (which occurs only in Beowulf, and only there in 1.443 --referring to Heorot) -- the aboate warriors; heal-aern and heal-reced add nothing to the idea at all; Finally they all represent one and the same hall. The simplex sele seems to be a favorite in these compounds, but its root meaning is merely 'dwelling'; heorot is called hring-sele, but so is the dragon's hole $(2830,3053)$. only incidentally does the poet sketch for us the appearance of the hall. What did it look like, this best of hall-houses? Beorht, betlic, heah, maest micel, foremaerost, geatolic, faeger, we are told that it was, but an image therefrom refuses to rise. Here a detail, and there another, starts out in the course of the poem, but the picture is not complete. It was horngeap (81), timbred, gold-fah (307), irenbendum fiaest (997), but not all at once are we told these things. 
When Vulcan fashioned the shield of Achilles Qll 'the details of the work were set forth; when the Jewish hero built a temple, Jewish literature preserved a minute account of its appearance; but when the "ruler of the Bright-Danes" built Heorot, thus is the story told:

him on mod bearn I. 67 .

paet (he) beal-reced hatan wolde

medoaern mices

men gewyrcean

ponne yldo bearn

aefre gefrunon

ond paer on innan

eall gedaelon

geongum ond ealdum, swylc him God sealde

but on folcscare

ond feorum gumena

Đa ic wi de gefraeyn

weorc gebannan

manigre maeg $\nmid e$

geond pesne midangeard

folcstede fraetwan. Him on fyrste gelomp

aedre mid yldum

paet hit weard ealgeaso

healearna maest; scop him Heort naman

se - $p$ e his wordes geweald wide haefde.

$\mathrm{He}$ beothe aleh,

beages daelde

sinc aet symle.

Sele hlifade

heah ond horngeap

heado wylmas bad

lat an liges."

And thus we are left glimpsing the towering gables 
above the fog that surrounds the base, while the poet hastens on to graver matters:

"ne waes bit lenge pa gen paet se ecyhete a $p$ umsweorum aefter waelnipe waechan scolde".

His interest is not in the concrete. He would have you believe that Hrodgar lived in a hall worthy of the "protector of the scyldings"; then he would turn to the worthiness of the heroes themselves. of the details about the furnishing and arrangement of the house, Dr. Hall finds the following mentioned. bur, brydbur, (women's apartment), hrof, weall, flet, and flor, stapol, web aefter wagum, durn, heorras, syll, benc (ealo-benc, medu-benc)setl (medusetl) heah-setl, bregostol, gifstol, gumstol and yppe. It is said to be "horngeap."

In almost every case, the poet mentions these thing merely by the way, as though the reader had already a clear picture of the scene of the narrative. One experiences a species of surprise in learning that there was tapestry on the walls of Heorot. In short, the appearance of these concrete details leaves one with the senge that a sudden wide flash of light had given a swift glimpse of the outline of many things only to go out again and make one more conscious of the darkness. 
What shape was Heorot? How wa it "gold-adorned?" Where was the bur? What is meant by "im under eoderas?" Surely not all the people dwelt here. Where were the homes of the tillers of the soil? Were there halls of other lords near? It is dark, and we may not see.

\section{Wardress}

II.

If we are to look for concreteness anywhere, we may certainly expect to find it in accounts of the array in which the warriors went into battle, but even here, though the terms are numerous, the objects are, after all, few in number and the resultant picture certainly limited.

To begin with the dress, the following quotation from Miss Keller's dissertation, Weapon Names in Anglo1 Saxon, bears its own comment;

"The frequent mention of the byrnie in Beowulf and other poems leaves no room for doubt that it was known at an early period among the Anglo-Saxons, and not only the lorica squamata (scale armor), but the lorica

1. Anglistiche Forschungen 15, p.100. 
hamata, or chain mail, is frequently referred to. Of the thirteen words employed to designate the coat of mail in Beowulf byrne occurs most frequently, to which are applied the various epithets of har, hringed, gebrogden, hond-bocen, beorht, and sid, to which may be added the numerous compounds such as gud,-heard-, here-, isern-land -iren byrne.

"Of the countless circumlocutions of these words, waed, gewaed, with its compounds here-, hilde-,gut-, breost-, and eorl-waed; hraegl together with its compounds, and serce, are among the most important and frequent. Such expressions as heado-reaf, beaduscruda, fyrd-hom, hilde-sceorp, here-pad occur only once in Beowulf, although found in other poems. . . All of the above mentioned words refer, as a rule, in simplex to clothing in general, but in the poems are used with reference to the coat of mail."

Thus the epic shows us briefly the chain armor of the arrior. But did the Anglo-Saxons wear no other dress? Beowulf is said to don his armor (1441). What was he wearing before putting it on? The hraegl, Dr. Hall says, may have signified a mantle or cloak, 
(1195,1217). But many of the words used of the battle-shirt are merely general terms for dress. We wonder how Wealhdeo was clad; this is no savage society, and we look for robes worthy of a queen who is "cynna gemyndig(113)", "mode gep ungen"(624). We are told only that she was "gold-adorned" and went "under gylanum beage."

For contrast we look back to the world of Homer. In the Iliad XIII, 185, we behold the Ionians with trailing tunics and, in Book II, 42, Agamemnon when he "donned his soft tunic fair and bright, and cast about him his great cloak, and beneath his glistering feet he bound his sandals." ${ }^{1}$ Before us in Book XIV, I70, Hera "clad her in her fragrant robe that Athene wrought delicately for her, and therein set many things beautifully made, and fastened it over her breast with clasps of gold. And she girdled it with a girdlo arrayed with a hundred tassels, and she set earrings in her pierced ears, earrings of three drops, and glistering, therefrom shone grace abundantly. And with a veil over all the peerless goddess veiled herself, a fair new veil, bright as the sun, and beneath her shining feet she bound goodly sandals."

1. Lang-Leaf- Myer translation. 
To return to Beowulf, in dressing him for battle the anglo-Saxon warrior added to the byrnie the helmet and shield. The picture of the helmet is fairly complete in the epic. Dr. Hall notes the term helm, which is, in different places, headd-steap, hwita, sincegeweordad, besette swinlicum, heard, hyrsted golde, faettum befeallen, brun-fag, omig, entisc, has hleorbeorge, cheek-pieces (?), and wala, a rim or roll, which is wirum bewunden, and bears on its crest usually a boar image, eofor irenheard, or swin ealgylden. Miss Keller cites descriptions of grave-finds which suggest that the mention of the fore-going words would call up quite distinct images in the minds of the narrator's audience. However, the word helm is a very general one, which means 'protector' and is so used in Beowulf, itself,

" hie huru heofena helm (God) herian ne cupon" 182, The shield, which, according to Tacitus, is genuinely Toutonic, whereas the helmet and byrnie were foreign borrowings, is designated by a number of names. of these Miss Keller says, "In the glossaries the Latin words for shield seem to be used absolutely without reference to the distinction between the various kinds of shield, the Latin scutum, pelta, parma, etc., being glossed indifferently by scyld, bord, etc., so

1. See Miss Keller's article,p, 68 and 79 Ibid $p, 70$. 
that no conclusion as to the shape of the Anglo-Saxon shield may be arawn from the use of the Latin terms. .... The word lind is poetic only, found frequently in Beowulf and other poems, together with rand, or hilde-rand -.. more frequent in Beowulf than scyld .... and bord, bordwudu, pointing clearly to the material of which the shield was made." She aays that geolo-rand of B.438 may be taken as a reference to a golden brand encircling the shield rather than to the yellow color of the linden-wood, and she calls attention to the fact that "Boewulf orders an iron shield that will withstand the terrible fire of the deagon." From old manuscripts and grave-finds she reconstructs for the reader the old Anglo-Saxon shield. From the epic Beowulf, then, the hero steps forth, clad in a battle shirt of chain mail, made of iron rings, sometimes adorned with gold,1.552, carrying a shield of linden-wood (for which, on one occasion, a shield of iron was substituted), having perhaps some sort of ornamental boss --cf. byrduscrud as discussed by Miss Keller p.267 -- and finished with a rim of metal,-- carrying such a shield, and wearing on his 
head a helmet as described before. This is the concrete result of 49 different nouns denoting dress, i.e., it is the result of putting them all together $f$ their descriptive adjectives; at no one point does one get a full picture, even one so bare of detail as this.

\section{Weapons.}

III.

In an epic, the theme of which is warfare, one is not surpised to find an almost affectionate attention paid to the weapons of the warrior, his spear and particularly his sword.

Miss Keller"finds that the spear was the possession of every warrior, whereas only a chief or degn of high rank owned a sword. She notes that the spearshaft was of ash-wood -- hence, garag aescholt ufan graeg B.330 -. and that the gar was the heavier, the darod, the lighter spear; that the swords were often richly adorned, particularly as to the hilt, were two-edged usually, and fastened to a strap or chain called the fetel. "Mece, sweord, secg, and heoru. are 
synonymous terms, the last two being poetical words. Bil meaning sword is also found only in poetry, being especially frequent in Beowulf, but in the glosses is used to translate falcastrum, 'scythe.'

The sword and spear were the most important weapons. In adition, there was the seax, a one-edged sword or knife, described as brad and brun-ecg B.1545. Stjerna thinks that both the one and two-edged swords were necessary for complete armor; he calls attention to the fact that Grendel's mother possessed two swords (at least, a second hung upon the wall of her den) and that Beowulf was equipped with two in his fight with the dragon. The seax, however, is mentioned only twice in the poem (called waelseax 2703). The Anglo-Saxons also fought with arrows, but mention is made of these only nine times, including the terms flanboga, horn-boga, flan, sceaft, strael, and here-strael. The word horn-boga seems to indicate that the material of the bow was covered or tipped with horn.

When the poet considered these weapons, he looked at them in two ways. There are lines in which

2. Essays on Beowulf p.20. 
the sword or spear is set forth in the bare fact of it, as a weapon, iron, hard etc. And there are lines in which the sword seems regarded as endowed with a special nature, a capacity and desire for killing, in which the poet would raise, not a clear image of it as a physical concrete, but a feeling attitude toward or an abstract idea about the weapon. on the one hand, we have blodigan gare (2440), sweord swate fah (1286), ecg waes iren (2778), wreoden-hilt (1698), and that delightfully vivid line: fordon sceal gar wesan monig morgenceald mundum bewunden (3021) -to mention only a few instances of concreteness. Agrinst these stand such phrases as mid gryrum ecga (483), sige-eadig bil (1557), leoflic iren (1809) and the kennings, fela laf (1032), hilde-egese (3154) maegenfultum (1455), and gud-wine (2735). The concrete details outnumber the abstract and I think that, though very few weapons are shown and only one of those, the sword, in detail -- the spear is mentioned only 14 times in the epic, including the eofor-spreot, 'boarspear', and the waelsteng, or pole on which Grendel's head was 
carried -- still for the poet's audience and for those of us who are familiar with archaeology, the language here must be regarded as concrete. However, beside these lines one can not help holding those others, the passages in which the image of the sword seems dim in the poet's mind and the idea of destruction or victory in connection with the sword becomes the focal point.

This wavering of interest between the appearance of the weapon and an abstract character which he assigns to it is shown in the description of Hrunting, where the narrator throws out roughly a few details about its appearance, and then falls into the swing of a full sentence when he speaks of its might and trustworthiness.

"waes paem haeft-mece Hrunting nama 1457 paet waes an foran eald-gestreona ecg waes iren ater-tanum fah ahyrded hea po-swate; naefre hit aet hilde ne swac manna aengum $p$ ara- pe hit mid mundum bewand se-đe gryre-sidas gegan dorste folc-stede fara; naes paet forma sid paet hit ellen-weorc aefnan scolde." 


\section{The Ship.}

IV.

To seek out his enemies and to secure booty, the Northern warrior traversed the sea in ships. Evidently he loved his ship as good sailors have always done, but he particularizes very little about it in his poetry. One is struck again with the looseness in the use of terms in Beowulf.

Schnepper in his dissertation Die Namen der Schiffe und Schieffsteile im Altenglischen, says,

"obgleich ala wort scip fur alle fahrzeuge ohne rücksicht auf ihre form oder grösze gebraucht werden konnte, scheint es doch im engeren sinne nur fur gröszere schiffe angewendet worden zu sein;" and in another paragraph, "Im allgemeinen teilte man alle Schiffe nach ihrer grösze in zwei klassen, nämlich boote (bat, naca) und schiffe (scip)." Still he adds later, "Beide ausdrilcke (bat and naca) scheinen vorzugs weise der gehobenen dichterischen sprache anzugehören, da sie äuszer in glossen, in der prosa nichtbelegt sind. übrigens wird in der poesie für ein und dasselbe fahrzeug bald scip, bald naca oder bat geschrieben."

1. Dissertation Kiel, 1908,p.18. 
There are, then in Beowulf a series of nouns all of which denote ship without distinction and without contributing modifying details -.- scip, naca, bat, sae-bat, ceol, faer, flota, and the poetical terms, sae-genga, yd-lida, sae-wudu, sund-wudu.

Here and there the story-teller mentions some part of the ship, e.g. the ancor (303) and (1883), the ancorbend (1018), the bolca (231), the sal (302, 1916) the segl (1906), stefn (212), tar in the compound niwtyrwed (295). Note how scattered are the items. Bundenstefna hringed-stefna, wundenstefna show us the twisted or curved prow of the boat, and wudu wunderheals (298) and flota famigheals (218) present the same thing even more vividly. Beyond this we see nothing of the "good wave-travereer."

\section{Valuables.}

$\mathrm{V}$.

Under the heading of valuables are to be included objects made of precious metals or adorned with gold and precious stones, things which were found in the 
treasure hords of the Anglo-Saxons, regarded as worth having for their intrinsic value, rather than for the use that could be made of them, although they were sometimes useful, too. Because weapons have already been discussed they are omitted here, though they were among the objects most treasured by the Anglo-Saxons. Among the distinguishable objects of value, Dr. Hall notes, (1) vessels: the flagon (orc), the cup (bune, dryncfaet, ful, waege) and the dish(disc), beside the general work for vessel, fatu, with its compounds madmfaet and wundorfaet, the first element of which indicates costliness and curious workmanship, but does not call up an image of it;(2) ring, circlet, diadem (beag, which word is also used in the sense of money, possessions; likewise hringas=money, valuables decorationsl; necket, collar, carcanet (beag, healsbeag, hring, mene); bracelet (earmbeag, earmhread); breast decoration (breast-weordung, which is essentially an abstract word), sun-shaped ornaments (sigle); to these are added the sinc-faet, casket (?) setting of jewels (?) and the eorclanstan precious stone, of which sievers", regarding the word as related to the chaldean jarkan, says, "Der jarkan ist ein'gelblicher edelstein',

1. "Beitrage", 12, pp 182-3. 
wahrscheinlich topas, und in der glossierung im Spelmanschen Po.118, 127 steht wirklich eorcanstan für topazius."

Beside these particular names for precious objects, Hall records the vague general words for treasure, much more often used than the foregoing, very loose in application, rich in compounds, and suggesting that the general idea of vast wealth, unlimited by specific details, appealed especially to the Anglo-Saxon imagination. Only one clear reference to precious stones appears, as we have seen. Iron has been mentioned in connection with armor, but gold is the metal of which the poet delighted to speak, gold which was wunden, brad, faeted, haeden, unrim (twice).

\section{Miscellaneous}

VI.

Having reviewed the large groups of concretes, it will suffice to mention with little comment the other things which Dr. Hall finds in Beowulf;

1. Drinks: ealu, beor, medu, win -- words found most often in compounds. 
2. Tools: fel and hamer.

3. Musical instruments: horn (mentioned three times), byme (once), hearpe (five times). However, gomen-wudu pccirs twoce and gleobeam once, showing the writer's interest in the emotions awakened by music.

4. Gallons: galga, galgtreow.

5. Roads: straet, weg, paed, stig. The first was probably artificially built.

6. Trappings of a horse: sadol. A bit is inferred from gebaeted (1399) and some sort of headgear from faetedhleor (1036).

7. Wagon: waen.

8. Bed, usually used in a figurative sense according to Doctor Hall.

9. Banner: segn, cumbor. 
F. Some Terms and Accounts of Action which Give Objectivity to the Poem.

$$
-1-
$$

Words for Battle

beadu

Battle (T. ba to beat), B. T. translates it battle, war, slaughter, cruelty. Hence it would seem that the word tends to become abstract. In Beowulf: had bolgen-mod beadwa ge $p$ inges B. 709; braegd fa beadwe heard fa he gebolgen waes 1539 . Gefeoht

Fight (T. feht to fight). In Beowulf: paet waes fech-leas gefeoht fyrenum gesyngad 2441; Meaht đu, min wine, mece gecnawan fone fin faeder to gefeohte baer geweorc

Work of war. In Beowulf only: no ic me an here-waesmum hragran talige gud-weorca fonne Grendel hine 678; on gylp-spraece gut-geweorca 981; cf. also 1825. gewinn

Struggle, fight, tumult (T. ven to labor), struggle, win by struggle. In Beowulf: waes paet gewin to strang B. 133 (meaning tribulation here, Grein thinks); waes paet gewin to swyat, lap ond longsum, te on da leode becom 191; pa hie gewin arugon heard - hicgende, hilde-mecgas 798; 
he fram Sigemundes secgan hyrde.. Waelsinges gewin 877; under yda gewin 1469; ofer eald gewin eagum starige 1781; he paes gewinnes weorc prouade 1721; fyrn-gewinn.

\section{fyrn-gewinn}

Ancient war. In Beowulf (only); on đaem waes or written fyrn-gewinnes 1699.

guad

war, battle, (T. gen to beat; gunp io fight); a pootical word, according to B. T. In Beowulf: Iig ealle forawealq. - para-de aer gud fornam 1123; Haedeynne weard Geata dryhtne guct onsaege 2483; cf.also $1658,2536,527,483,630$, $1472,1535,1997,2353,2356,2491,2878,438,603,2512$, $2543,1958,2178$.

$\underline{\text { hild }}$

Fight, battle. ( $T$. hel to beat, break). In Beowulf: gif mec hild nime 452,1481; Siddan Heremodes hild swedrode ea(r) fod ond ellen 902 (battle power?); swa him aer gescod hild aet Heorote 1588 (gud-werigne 1586); faet-de gar nymed hild heoru-grimme Hre ples eaforan 
1847; cf. also $2076,1460,1659,2258,2575$, 2684, $2916647,1990,2298,2952$.

hlem

Crash, in. (T. hlem to sound). The word appears in Beowulf only in compounds.

hilde-hlaemm

Crash of battle. (T. hlem to sound). In Beowulf (only). fela nida gedigde, hildehlemma 2351, 2544 ; eft paet geeode ufaran dogrum hildehlaemmum, pa hyne gesohtan sige-peode hearde hilde-freca, nida genaegdon nefan Hererices. B. 2201 .

Uht-hlem

Tumult of battle before light. In Beowulf (only): awa begylpan pearf Grendeles maga aenig ofer eordan uft-hlem fone 2007 .

$1 \mathrm{sc}$

I)Play, contest, fight.

2) Gift.

The simple always has something of the second meaning in Beowulf,e.g., ofer heat u bringan lac ond luf-tacen 1863; cf. also 43, 1868, 1584. beadolac

Battle. (T. laik to jump, play). In Beowulf: 
hit (the sword) waes mare donne aenighon oder to beadu-lace aetberan meahte 1561 . gelác

In Beowulf: đonne sweorda gelac sunu-Healfdenes efnan wolde 1040; ecga gelacum 1168 . heado-lac 1

Battle (T. hap to fight; laik to spring,play).

In Beowulf (only): wigendra hleo . . lifigende cwom head-0-laces hal to hofe gongan 1974;

Breca naefre git aet heado-lace ne gehwaep er incer, swa deorlice daed gefremede 584 .

orlege

War, strife, hostility. 10. Sax. orlegas, battle cry; Icel. or-lygi, fate, battled. In Beowulf: ponne we on orlege hafelan weredon 1326; se daes orleges or onstealde 2407 . orleg-hwil

Time of combat, of struggle. In Beowulf (only): hwylc (orleg)-hwil uncer Grendles weard on tam wange 2002; N ys leodum wen orleg-hwile 2911; Fela ic on giogote gud-raesa genaes orleg-hwila 2427.

1. heado-- appears only in poetry and only in compounds. No other derivatives from its base are found in any of the Germanic languages. 
plega

(T. pleg to beat. However, Torp expresses a doubt whether Agr. plegian and plega come from this form).

1. Quick movement; 2. fight, 3. play. The simplex does not appear in Beowulf. lind-plega

Battle of shieldbearers. In Beowulf (only): to đam Iind-plegan 1073; cf. also 2039. raes

Attack. (T. ras, res to plunge or rush in). In Beowulf: đaet he gude raes . . . fremman sceolde 2626; (he) gude raesum . . . swealt bille gebeaten 2356 . gud-raes

Battle rush, violence, attack. In Beowulf: geald pone gud-raes Geata dryhten 2991; Grendle forgyldan gudraesa fela 1577; Fela ic on giogode guđ-raesa genaes orleg-hwila 2426. hand-raes

Battle (with hands) Ic sceal ford sprecan gen ymbe Grendel paet du geare cunne sinces brytta, to hwan syđdan weard honàraes haeleda, B. 2072 (only). 
heado-raes

Rush of battle. In Beowulf (only): heaporaes for-nam mihtig mere-deor 557; tealh du heado-raesa gehwaer dohte, grimne gude 527 .

hilde-raes

Rush of battle. In Beowulf (only): swylcum gifepe bid paet pone hilde-raes hal gediged 300 .

maegen-raes

Powerful onslaught. In Beowulf (only): maegen raes forgeaf hilde-bille 1519.

wael-raes

Deadly attack, battle. In Beowuff(only):

wael-raes weora wide gesyne 2947; me fone wael-

raes wine scildunga faettan golde fela leanode

2101; Denum eallum weard aefter pam wael-raes will a gelumpen 824; hwaeder sel maege aefter wael-raese wande gedygan uncer twega 2531.

sacu

Contention, hostility. (sag to track, hence pursuit strife here). In Beowulf: (sceal) sacu restan inwitnip as 1857; secce ne-wene to 
Gar-Denum 600; se- pe aer aet saecce gebad wig-hryre wadra 1618; ofsloh da aet paere saecce . . huses hyrdas 1665. of. also 953, 2612, $2659,2681,154,1977,1989,2347,2499,2562,2029$. wael

Grein gives three meanings:

1. The number of those selected by the Valkyrie for Valhalla, and hence a warrior fallen in battle, destruction. 2. The warrior's dead body. 3. The battle-field full of corpses. Torp, however, gives no support for the first definition offered by Grein. According to Torp, the Germanic base is vala, valu the corpse on the battle-field, the battlefield.

In Beowulf: byred blodig wael 448 (Grendel will carry off the bloody corpse); op-de on wael crunge feond-grapum faest 635; wael reafodon 1212; he (hrefn) wit wulf wael reafode 3027; sume on waele crungon 1113; naefre on ore laeg wid-cu $p$ es wig donne walu feollonl042. weorc

Work. The sumplex is to be discussed in a later list. 
beadoweore

Work of war, battle. Hwaedre hilde gefeh, beaduweorces 2299.

heado-weore

Opus belli: work of war. In Beowulf (only):

Heht da paet heado-weore to hagan biodan 2892 . wig:

1. Fight ( $T$. vih to fight);2 ability to fight. In Beowulf: fonne wig cume 23; wig ealle fornam 1080; waes paes wyrnes wig wide gesyne, nearofages nid 2316; gif he gesecean dear wig ofer waepen 685; waes his mod-sefa manegum gecyded, wig ond wisdom 350 (This last has the second meaning; like it are 1. 1042,2323,2348). For further instances, of. $2872,1083,65,886,1268$, $1084,1337,2629,1656,1770,1783$.

feđe-wig

Fight on foot. In Beowulf: nealles Hetware hremge porfton fecte-wiges 2364. paet me Hagenan hand hilde gefremede and getwaemde fedewige Wald.25.

wy Im

Surging, tumult 
heado-wylm

Direful surgings (of fire). A poetical word. In Beowulf: ( $S e l e$ ) heado-wylma bad ladan liges 82; aer he bael cure hate heado-wylmas

Wael, uht-hlem, hilde-hlem, lind-plega, furnish some materials for concreteness; we can glimpse the battle-fiedd strewn with the dead, hear faintly the uproar of the struggle, and get some sense of movement in the play of the shields. Beado-lac and heado-lac, raes and hand-raes, fyragewinn and fede-wig, serve to qualify somewhat the general concept of warfare, though very abstract.

Certainly, very little of the warfare in Beowulf could be represented pictorially -- not that anyone regrets this. To show the comparative absence of objectivity just where the ordinary thinker would expect to find it, I am adding here as graphic an arrangement as possible of what may, for convenience, be called (a) the outer and (b) the inner history of the fight with Grendel,1. 720-836 of Beowulf, with occasional omissions of a few words. 

rinca manigel

samod

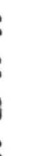$$
\begin{aligned}
& \text { swefan sibbe-gedriht } \\
& \text { samod }
\end{aligned}
$$

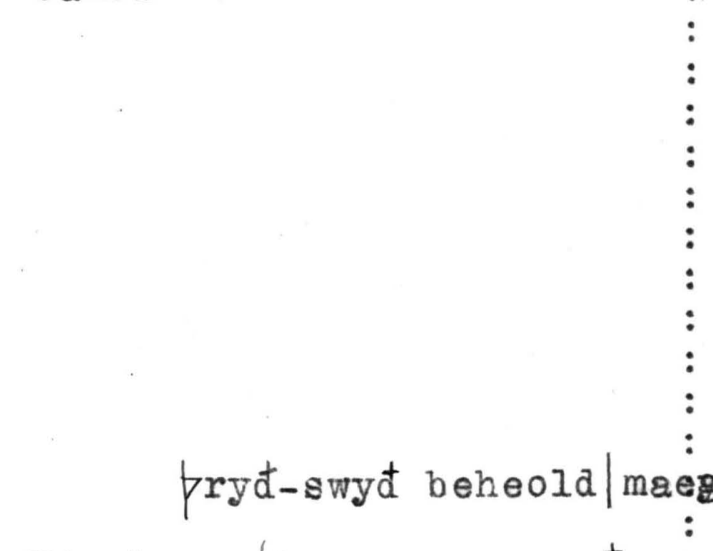

Higelaces/hu se man-scada

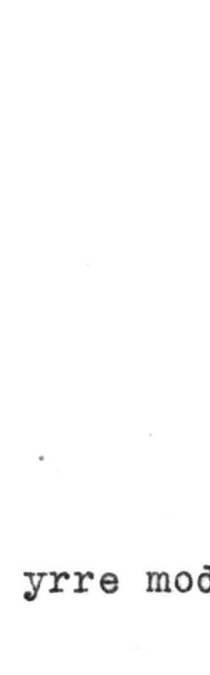


under faergripum|gefaran wolde): : Ne faet se aglaeca/ylan pohtel

ac he gefeng hrade/forman side: slaependne rinc|slat unwearnum: bat ban-locan etc.

$$
\text { Fordnear astop|nam } p a:
$$
mid handa|hige-pintigne/rinc : on raeste/raehte ongean/feond : mid folme|

:he onfeng hrape/inwit:pancum|

ond widearm gesaet|

: Sona paet on funde|fyrene : hyrde/paet he ne-mette|mid:dan-geardes|eor $p$ an sceattal :on el(d)ran men|mund-gripe :maran;| helon mode weard|forht : on ferhde

no $p$ y aer from meahte

:hyge waes him hin-fus/wolde :on heolster fleon/secan deofla :gedraeg;| ne-waeshis arohtod paer| 
up-lang astod ond :

him faeste widfeng.| Fingras: burston $\mid$ eoten waes ut-weara|: eorl furp ur stopl dryht-sele dynede|Denumeallưm weard|. . eorlum ealuscerwen|

Reced hlyngode $\therefore$ swylce he on ealder-dagum| aer gemette|Gemunde $p a$ se $\bmod (g)$ a maeg Higelace aefen-spraece

Mynte se maera|hwaer he meahte swa|widre gewindan/ond on weg fanon|fleon on fen-hopu; wiste his fingra geweald/on grames grapum|faet waes geocor sid|paet se hearm-scapa|to Heorate ateah. 
iren-bendum|

searo-poncum besmi fod

paer fram sylle abeag:

medu-benc monigl

mine gefraege|

golde geregnad, paer $p a$

graman wunnon!

betic ond ban-fag|tobrecan:

paes ne-wendon aer|witan

scyldinga|paet hit a mia

gemete|manna aenig

meahtel

nym $p$ e liges fae $p m$ :

swylge on swapule.| sweg up:

astag|niwe geneahhe|

para- $p e$ of wealle|wop

gehyrdon|gryre-leod galan| : sige-leasne sangl. . . $\quad$ :

Heold him to faeste:
Nord-Denum stod|atelic egesa| anra gehwylcum|

se-pe manna waes/maegene strengest|on paem daege|pysses lifes. Nolde eorla hleo| aenige 
(a)

(b)

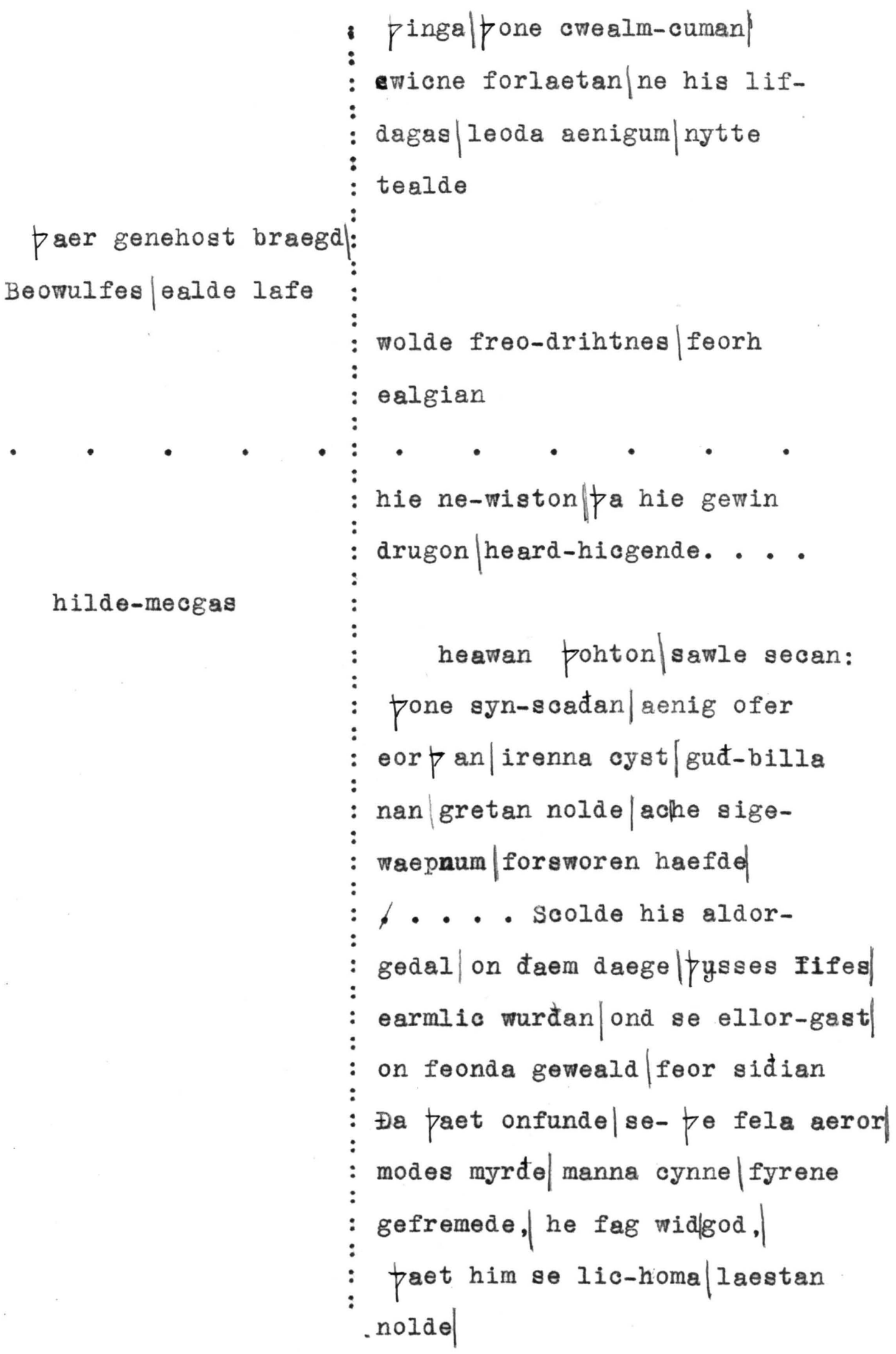


(a)

achine se modegal maeg Hygelaces|haefde be honda|

Iic-sar gebad|atol aglaeca|him on eaxle weard| syn-dolh sweotol; seonowe onsprungen|burston ban-locan|: scolde Grendel fonan: feorh-seoc fleon|under fenhleođu|secean wynleas wic|:

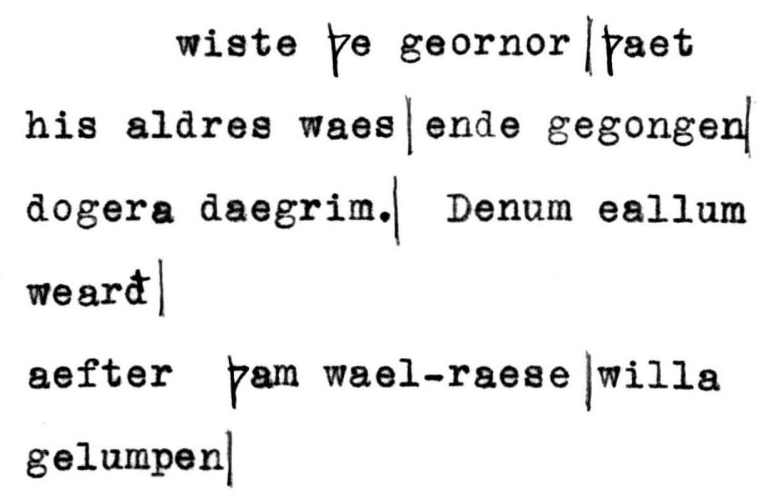

(b)

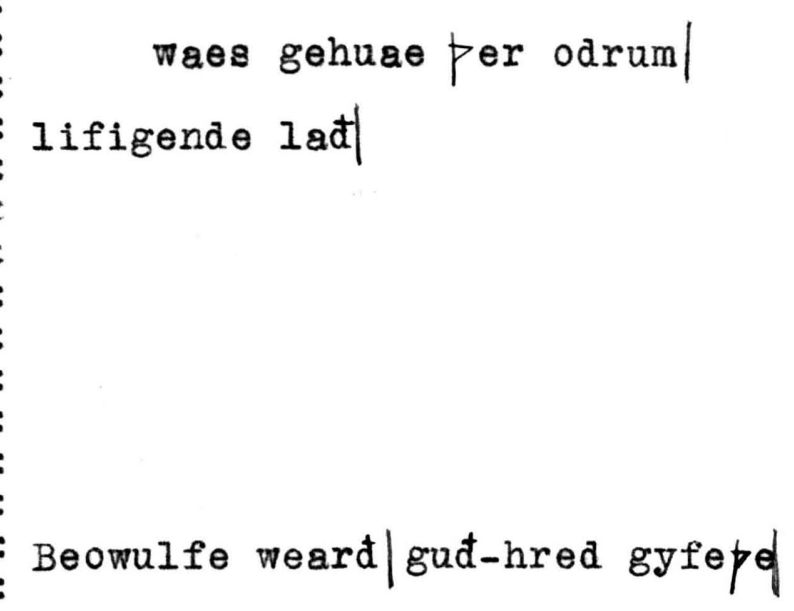

Beowulfe weard|gud-hred gyfepd

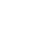


(a)

(b)

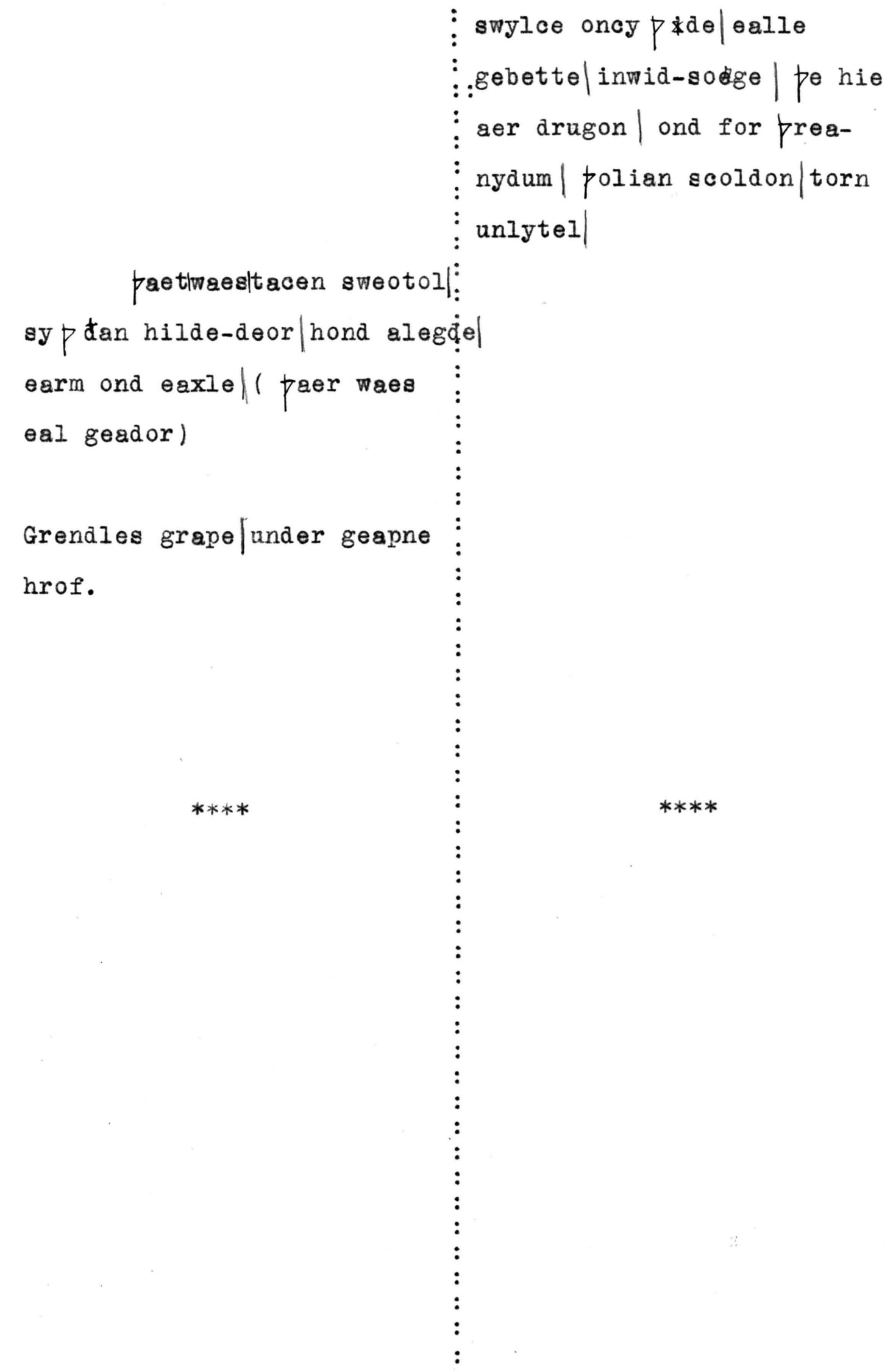




\section{x. Disposal of the Dead.}

I am here again indebted to $\mathrm{Dr}$. Clark Hall's 1

study for the following list of things:

Ad

Funeral pyre. In Beowulf: aet faem ade waes e p-gesyne swat-fah syrce ll10; Hildeburh aet Hnaefes ade 1l14; Him da gegiredan Geata leode ad on eordan 3138 .

Adfaru

Way to the funeral pyre. In Beowulf (only): Na is ofost betost paet we peod-eyning faer sceawian ond fone gebringan, pe us beagas geaf on ad-faere 3010.

bael

Funeral pile, balefire. In Beowulf: betst beadorinca waes on bael gearu 1109; on bael don 1116; hy hine ne-moston.... on bael hladan leofne mannan 2126 (Aeschere has been denied the burial rites); Hatad heado-maere hlaew gewyrcean beorhtne aefter baele 2803; paet waes pam gomelan gingaeste word . . aer he bael cure 2818; mid baele for (of the dragon); of. also 2322.

1. See next page. 
bael-fyx

Bale-fire. In Beowulf: ongunnon pa on beorge bael-fyra maest wigend weccan 3143 .

bael-stede

Place of the funeral pile.

In Beowulf (only): faet ge geworhton...

in bael-stede beorn fone hean 3097.

bael-wudu

Wood of the pyre.

In Beowulf (only): paet hie bael-wudu feorran feredon 3112.

baer

Bier: - Sie sio baer gearo aedre geaefned fonne we ut cymen ond ponne geferian frean userne 3105. "This was probably a portable bed, somewhat like that apparently intended for the body of the dead Viking which was found in the Golsstad ship".

1. "Index of Things Mentioned in Beowulf", appendix to his prose translation of Beowulf $(\mathrm{p} .209)$ and to his translation of Stjerna's Essays on Beowulf $(242, p)$ 
beoris

\section{Barrow.}

In Beowulf: Beorh eall -gearo wunode on

wonge 2241 (waeter-yđum neah, nearo-craeftum faest), hwilum on beorh aethwearf sinc-faet sohte 2299; Waes da gebolgen beorges hyrde 2322; Nelle ic beorges weard oferfleon 2524; stream ut ponan brecan of beorge 2546; under beorges hrof 2755; cf. 2529, 2559, 2580, 2842, 3066. All of the foregoing denote the barrow in which was found the dragon's hoard. paet ge geworhton aefter wines daedum in bael-stede beorh fone hean 3097-- Beowulf's barrow; similarly 2807. In 211, 3143, 222, 2272 the word means simply 'hill, height', as has appeared in another list. 
It is worth remark here that Beowulf's barrow and that containing the dragon's hoard differed considerably in appearance. On a high point by the sea, over the remains of the pyre, Beowulf's men built the barrow with its high wall - and took ten days in building it. The treasure cave, on the other hand, though called stanbeorh V. 2213, and apparently intended as a burial place (1f. 2213-2270), is not an ordinary grave-mound. As Stjerna points out, ${ }^{l}$ it is, in one place, described as a cave under the ground(2410f); it had an arch of stone through which the dragon spewed forth fire(2545); it is a huge treasure house(2279) upheld by stone arches and firm pillars within(2718).

hloew

In his note on stjerna's discussion of this word ${ }^{2}$ Doctor Hall says that etymology does not warrant our considering the term to mean more than 'mound' or 'elevation'. In Beowulf: hlaew oft ymbe-hwearf ealne utan-weardne (the dragon is pictured as circling around the barrow, seeking the thief) 2296; Đa ic on hlaewe gefraegn hord reafian 2773; he ofer willan giong to daes-de he

1. "Essays on Beowulf", p 37 .

2. "Ibid", p 206. 
eord-sele anne wisse hlaew under hrusan 2411

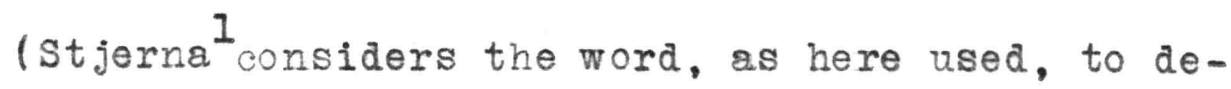
signate the grave chamber as distonguished from the outer walls; Schucking's glossar so translates the word; but, as we have seen, Clark Hall objects); Hatad heado-maere hlaew gewyrcean beorhtne aefter baele aet brimes nosan 2802 (Beowulf's Barrow); similarly 3157, 3169; Wand to wolcnum wael-fyra maest hlynode for hlawe 1120 (Here is meant the mound on which the funeral pyre was built); $I$. 2212 (2211, according to Hall) is doubtful as the manuscript is not clear; Schücking and Eoltthausen follow zupitza in reading on heapo-haewe, Sedgefield has heaum hae Wyatt-Chambers healum hopel. hodma

Covering, here the grave. In Beowulf: ridend swefad haeled in hodman 2458 .

Three times do funeral ceremonies take place in the course of the narrative. Upon the death of Scyld, "his fast friends" laid him in a "ring-prowed vessel" and placed beside him "many treasures, ornaments from far-off lands".

"Essays on Beowalf", p 206. 
The narrator had never known a ship "more fairly fitted out with war-weapons and battle gear, with bills and wi th byrnies". "They set a golden banner high over his head". And the ocean bore him away, no man knew whither.

In all the puzzling Finn episode nothing else stands out with half the clearness of the scene at Huaef's funeral pyre; leading his audience away from the council hall where the survivors are making the ir compact with Finn, the poet shows them in seventeen short lines the last rites of the dead hero. Before them "the best of War - Schildings, of battle-heroes" lies "ready on the pyre". The blood-stained corselet and the helmet with its boar-crest leal-gylden, irenheard) are pointed out in the subdued and solemn manner befitting the occasion. Hildeburh enters, and with the authority of one greatly bereaved, commands that her son be consumed on this same pyre. First she weeps upon his shoulder, and then as is fitting, she sings the dirge for the dead. While she does so, the warrior mounts upward in the greatest of bale-fires". We see the head consumed, the gashes gaping, the blood springing forth. The poet closes with a touch of awful finality, "Iig ealle forswealg .... ... waes hira blaed scacen". The scene seems to me to be one of unusually vivid pictur ing. The mood of the pas-

1. According to Holder and Schucking; Hol thausen has eame for MS. earme. 
sage is made evident only through concrete details.

There is enough of concrete in the description of Beowulf's funeral obsewuies, the firmly built pyre around which helmets and shields and corslets are hung, the great fire (with its smoke and its roaring) which consumes the bony flame, the aged woman who, with hair bound up in token of grief, sings a dirge for the evil days to come, the high barrow which the Geats build over Beowulf's ashes, close by the sea, the ornaments which they place therein, the march of the twelve about the completed barrow, singing dirges -- all these details are carefully presented. But in the account the writer finds place, as he did not in the Finn episode, for such lines as,

"Higum unrote

mod ceare maendon mon-dryhtnes owealm; 3148-9

"hie hyre (hearn-dal gas hearde on (ar) ede, wael-fylla worn wigl lend es egesan hy (h) do ond haef(t) nyd" 3153-55.

"eahtodan eorlscipe ond his ellen-weorc duguđum demdon swa hit ge-defe bid paet mon his wine-dryhten wordum herge ferhtum freoge ponne he ford scile of Iic-haman lysed weorđan". $3173-77$.

It shoud be noted that, as stjerna points out, there (Note carried to next page). 
is some inconsistency in the account of the burial, that the treasure from the dragon's hoard is said to be burned wi th Beowulf, and is then later said to be put in the barrow, that the corselets are declared to be shining which, earlier, were described as rusty. However, this does not alter the fact that the description is here fairly objective and vivid. Of the burial ceremonies of the past the three scenes leave us a comparatively clear picture.

$$
\text { Still, beside this picture arises in one's mind the }
$$
noble scene of grief when Achilles mourned for Patroclas (Iliad XVIII); ${ }^{1}$ where the narrator delights in giving details as the Beowulf poet does not.

"Thus spake noble Achilles, and bade his comrades set a great tripod on the fire, that with all speed they might wash from Patroclas the bloody gore. So they set a tripod of ablution on the burning fire, and poured therein water and took wood and kindled it beneath; and the fire wrapped the belly of the tripod, and the water grew hot. And when the water boiled in the bright bronze, then washed they him and anointed him witholive oil, and filled his wounds with fresh ointment, and laid him on a bier and covered him with soft cloth from head to foot, and thereover a white robe. Then all night around Achilles fleet of foot the Myrmidons made lament and moan for Patroklos".

(note I contd. from preceding page). "Essays on Beowulf", pp 198-200. 1. Lang-Leaf---Meyer translation p 276. 


\section{Court Etiquette}

Dr. Clark Hall, in the introduction to his prose translation of Beowulf, cites several pasages as evidence "that court etiquette is quite a prominent feature in the first part of the poem." other passages than those he cites also appear.

There is first the etiquette for the reception of strangers. After the coast-guard has satisfied himself of the good intentions of Beowulf's band, he offers to guide them to Heorot and to set a guard over their ship as it lies on the beach. Then, having led them to the point where they can see "the Bright hall of the Brave," he turns his horse, makes them a little farewell speech, and goes back to his post. Wulfgar, the herald of King Hrodgar, comes out to meet them as they approach the hall. Under the cloak of compliments he inquires their business, but Beowulf with quiet stateliness intimates that he is reserving his message for the ears of the king himself. Accordingly, Wulfgar goes back to Hrodgar, and standing at the king's shoulder announces the arrival of the Geats; whereupon Hrodgar bids him summon them into the court. The Geats in entering, however, must leave their shields and 
spears outside, and wear only the helmet and corselet. Upon Beowulf's return to the court of Higelac, much the same ceremonial of reception is observed; the degn on guard at the shore assists him in landing and someone else announces his arrival to Higelac. However, of course, he is no stranger here, and the formalities are therefore cut short.

Throughout the poem are touches, suggesting what was considered courtesy in the ordinary life of the hall. When Wealhdeo, Hrodgar's queen, enters the hall -- and we are expressiy told that she was "cynna gemyndig" -- she first greets all the men; then, meadcup in hand, she passes round the room and proffers the cup to each of those present, to the king first, then to the "seniors and juniors", and finally to Beowulf. To him, in particular, she makes a formal speech of welcome, to which he replies with a dignified beot, which greatly pleases the lady. The duties of queenly courtesy performed, Wealhdeo takes her seat beside the king. Iater, we see Freawaru, too, performing, in her father's hall, the same gracious task of serving the warriors. When Hrodgar would retire to his bower, all arise and the old king wishes Beowulf good fortune and confers upon him power over the 
whole house. On the morning after the death of Aeschere, Beowlf, ignorant of the disaster, is represented as entering the hall with his band to salute Hrodgar and to inquire whether he had enjoyed a quiet night. We are told that on the night following the fight with Grendel's mother, one of the degns of the hall (it seems best to give no more definite title to selebegn 1794) assisted the tired warrior and guided him to his resting place.

The ceremonials in connection with the honoring of the victorious hero are not to be overlooked. After the fight with Grendel, there is singing and harp music, and the rehearsal of old stories within the hall; there is the conferring of gifts by both the king and queen and the making of long complimentary speeches. Hrodgar does not renew his gift-giving after the fight with Grendel's mother, but Beowulf, before his departure, bestows a handsome sword upon the boatkeeper, and either he gives back to Unferth the sword lent him or Unferth gives him another sword, according to one's translation of the puzaling lines 1807-1812. Finally, all of the treasure which Beowalf has gotten at Hrodgar's court, he presents to Higelac, his overlord at home. 
All these details are interesting to the student of early society, but they are chiefly valuable to the poem because they contribute to the objectivity of the whole. 


\section{G. A Few Very Vague concretes and Some}

Abstracts of Which the Beowulf Poet Seems Fond.

This section is divided into (I) some vague concretes, and, (2) abstract terms which are often used.

I

weore

(1) Word, deed. In Beowulf: $\boxplus a$ ic wide gefraegn weorc gebannan.........fole-stede fraetwan 74; Ic faet unsofte eldre gedigde wigge under waetere weorc gene $\nmid$ de earfodlice 1656; secg weorce gefeh 1569; sceal scearp scyld-wiga gescad witan worda ond worca 289; ic, pooden min pine leode weordode weorcum 2096; daer aenig mon wordum ne worcum waere ne-braece 1100; he mec frerman side $w(e)$ ordum ond worcum 2893; 
2) Burden, pain, labor. In Beowulf: he daes gewinnes weorc đrowade, leodbealo longsum 1721; feower scoldon on paem wael-stenge weorcum geferian ........ Grendles heafod 1638.

beadu-weorc

Word of war. In Beowulf: Hwaedre hilde gefeh beadu-weorces 2299 .

ellen-weorc

Things bravely done. In Beowulf: gif $p u$ paet ellen-weorc aldre gedigest 661; we paet ellenweorc estum miclum feohtan foohtan fremeldon 958. hit (the sword) ellen-weorc aefnan scolde 1464; hlaford us pis ellen-weorc ana adohte to gefremanne 2643; eahtodan eorlscipe ond his ellen-weorc dugudum demdon 3173; he nida gehwane genesen haefde sliđra geslyhta sunu Ecydiowes ellenweorca 2399. heado-weorc

Work of war. In Beowulf (only): Niht-weorce gefeh ellen-maer $\nmid$ um 827 (Beowulf is represented as rejoicing in his victory over Grendel).

geweorc

Work. The prefix ge - had originally collective force, but Wright ${ }^{l}$ says that it was later used as an intensive particle. In Beowulf: paet is Hredlan

1. "Old English Grammar", p 290, sec. 574. 
laf Welandes geweorc 455; god ond geatolic giganta geweore (the sword) 1562; wundor -- smi p a geweore 1681; seah on enta geweorc 2717 - the barrow containing the hord; hord reafian eald enta geweorc 2774; paet dam peodne waes siđas(t) sige-hwila sylfes daedum worlde geweorces 2711 .

aergewe orc

Ancient work. In Beowulf: Gylden-hilt ... enta aergeweorc 1679 .

fyrn-geweorc

Ancient work, or work finished long ago. In Beowulf: Frea sceawode fira fyrn-geweorc 2286 - the hord.

guct-gewe orc

Work of war. In Beowulf (only): No ic me an here-waesmun hnagran talige gud-geweorca fonne Grendel hine 678; on gylp-spraece gud-geweorea 981; Gif ic ,... maeg .... maran tilian ... donne ic gyt dyde gud-geweorca 1825. hond-gewe orc

Work of the hands. In Beowulf: he eordan gefeoll for daes hild-fruman hond-geweorce 2835. land-geweor c

Iand building. In Beowulf (only): hie wideferht leoda land-geweorc lap um beweredon 938Heorot. nip-geweorc

The work of fighting. In Beowulf (only): peah 
he rof sie nidgeweorca 683. (I have repeated here some cpp. found elsewhere for the sake of the camulative effect).

wundor

Wonder, portent, wonderful deed or thing. In Beowulf: eodon unblide .... wundur sceawian 3032 (it is not clear whether wunder denotes the fire drake or the fact that $B$. had killed the fire drake). .. mandor sceawian lapes lastas 840; maeg god wyrcan wunder aefter wundre 931; wundur on wealle 2759; wundur under wealle 3103; hine wundra faes fela swe lild te on sunde 1509. hond-wundor

Wonderful thing made by hand. In Beowulf (only): segn ealb-gylden heah ofer horde, hond-wundra maest 2768 .

nid-wundor

Wonder of the deep (according to Gr.); a wonder that bodes evil, a portent, (according to B. T.). In Beowalf: paer maeg nihta gehwam nid-wandor seon, fyr on flode 1365 (only).

searo-wund or

Wonderful thing. In Beowulf: edde scealc monig ....... searo-wundor seon 920 (only). 
wundorsien

A wonderful sight, appearance. In Beowulf(only): Gold-fag scion web aefter wagum, wundor-siona fela 995 .

wyhn

Surging, boiling, tumult (T. Vel to seethe, be hot). In Beowulf: geofon ypum weol wintrys wylm(el) 516; flodes wylm 1764; od-daet deades wylm hran aet heortan 2269; purh waeteres wylm 1693; waes paere burnan waelm heado-fyrum hat 2546; Ic da daes waelmes pe is wide cud grimme gryrelicne grund-hyrde fond 2135; heortan wylmas 2507. breost-wylm

Thumult in the breast. In Beowulf: paet he pone breast-wylm forberan ne-mehte 1877 .

bryne-wylm

Fervor or surging of fire. In Beowulf: bolda selest bryne-wylmum mealt 2326 . cear-wylm (waelm)

Welling of care, agitation. In Beowulf: gyf pa cear-wylmas colran wurdap 282; him wif-lufan aefter cear-waelmum colran weordad 2066. fyr-wylm

Surging flame. In Beowulf (only): fyø-wylmum fah 2671. 
headu-wylm

Awful, hideous tumult, surging. In Beowulf:

heado-wylma bad ladan liges 82-fire; aer he

bael cure, hate heato-wylmas 2819.

sor h-wylm

F'luctuation of care. In Beowlf: ic paes mod- 
ceare sorhwylmum sead 1993; cf. also 904. Compounds referring to the sea have been cited elsewhere.

\section{II}

bealu

Evil, calamity, tribulation (T. balva evil, misfortune). In Beowulf: egeslic eord-draca ealdre be reafod bealwe gebaeded 2826; se- pe him bealwa to bote gelyfde 909; gyf him edwendan aefre scolde bealuwa bisigu 281; bona blodig-tod bealewa ge myndig: 2082.

cwealn-bealu

Deadly evil. In Beowulf (only): hit sceadenmael scyran moste cwealn-bealu cydan 1940. ealdor-bealu

Evil affecting life. In Beowulf: pu ondraedan ne dearft on pa healfe aldorbealu eorlum 1676. feorh-bealu

Deadily evil. In Beowulf: paer waes Hondscio hild(e) onsaege feorh-bealu faegum 2077; gud nimed, feorh-bealu frecne, frean eowerne 2537; similarly 2250; wiđ manna hwone maegenes Deniga feorh-bealo feorran feo pingian 156. hreder-bealu

Evil of heart, agony, a grievous thing. In Beowulf (only): se-pe aefter sinc-gyfan on sefan greote hre per-bealo hearde 1347 . 
leod-bealu

public calamity. In Beowulf (only): paet he paes gewinres weorc prowade leod-bealo longsum 1722; hio leod-bealewa laes gefremede 1946. morđor-bealu

Deadly hurt, murder. In Beowlf (only): heo under swegle geseon meahte mor por-bealo maga 1079; similarly 2742 .

niht-bealu

Nocturnal evil. In Beowrilf (only): on da leode becom nyd-wracu nip-grim niht-bealwa maest 193. sweord-bealu

Evil or hurt inflicted by the sword. In Beowulf (only): Fin eft begeat sweord-bealo sliden aet his selfes ham 1147 .

wig-bealu

Evil of war. In Beowulf (only): purh hredra gehygd higes cunnian wit-bealu weccean 2046 . aream

Singing, harmony (T. dru to make a noise); joy, jubilation. The idea of noise is always associated wi th the word, although we translate it 'joy'. In Beowulf: paer waes haeleđa dream dugud unlytel Dena ond Wedera 497; he dogora gehwam dream gehydre hludne in healle 88; fa he hean gewat areame bedaeled deap-wic seon 1275; siddan dreama leas 
in fen-freodo feorh alegde 850; Swa da driht-guman dreamum lifaion 99; Com $p a$ to recede rinc sidian areamum bedaeled 721 .

gleo-aream

Jubilation. In Beowulf (only): se here-wisa hleahtor alegde gamen ond gleo-dream 3021.

gum-dream

Joy of men. In Beowrilf (only): He ....... gumdream ofgeaf, godes leoht geceas 2469 .

mon-dream

Joy of men. In Beowulf: od paet he and hwearf mon-areamum from 1715; he pa fag gewat ... mondream fle on 1264 .

medu-dream

Joy of the mead-drinker. In Beowulf: ne-seah ic widan feorh ........ medu-dream maran 2016 . sele-dream

Joy in hall. In Beowulf: gesawon sele-dream 2252. eafod

Strength (T. $a b$, ob to work(?)) In Beowulf: frecne geneddon eafodpuncupes 960; eafop es craeftig 1466; paet pec adl odde ecg eafopes getwaefed 1763; he wid aglaecan eofodo daele eorlscipe efne 2534; hine mihtig god maegenes wynnum eafe $p$ um stepte 1717. Cf. also 902, 602, 2349. 
egesa

Horror, then object of horror ( $\mathrm{T}$. ag to be afraid). In Beowulf: Nord-Denum stod atelic egesa anra gehwylcum 784; egesan ne-gymed 1757 (more concrete); (wigen) des egesan 3155; eawed purh egsan 276; frec ymb-sittend egesan pywad 1827; pe mec gud-winum gretan dorste egesan deom 2736.

gled-egesa

Terror of flames. In Beowulf (only): gled-egesa grim 2650;

lig-egesa

Fiery horror. In Beowulf (only): longe hwile

ligegesan waeg 2780 .

waeteregesa

Terror or tumult of waters. In Beowulf: waeteregesan wunian 1260.

elien

Strength, vigor, courage, fortitude. (T. al to spur on, drive on; aljana eagerness, comrage). In Beowulf: hu da aepelingas ellen fremendon 3; Ic gefreminan sceal eorlic ellen 637; Wyrd oft nered unfaegne eorl, ponne his ellen deak 573; ne him paes wyrmes wig for wiht dyde eafot ond ellen 2349; ellen cyđan craeft ond cenđu 2695; Eft waes anraed nalas elnes laet .. maeg Hy (ge) laces 1529; 
(only): he mid dy wife wael-faehda dael saecca gesette 2028.

firen

Sin, crime, evil deed (T. ferina something extraordinary; ass. firen crime). In Beowalf: faehde ond fyrene 137; similarly 153, 879, 2480; hine fyren onwod 915; Mod Đrydo waeg, frecnu folces cwen, firen ondrysne 1932; Swa fela fyrena feond man-cynnes ..... oft gefremede 164; fyrena hyrde 750 -.- Grendel; se-pe of flan-bogan fyrenum sceoted 1744; feoh-leas gefeoht fyrenum gesyngad 2441 ; cf. also 628,811 .

gamen

Joy, gayety (T. gem to jump). In Beowulf: Gamen eft astah beorhtode benc-sweg 1160; nis hearpan wyn gomen gleobeames 2263; nis paer hearpan sweg gomen in geardum 2495; hleahtor alegde gamen ond gleodream 3021; (fuglum) to gamene 2941; gyrn aefter gomene, seođdan Grendel weard eald-geuwinna 1775 .

healgamen

Joy in hall. In Beowrif (only): donne healgamen Hro 7 gares scop aefter medo-bence maenan scolde 1066.

maerđo

Glory, fame, honor. In Beowulf: he ne -upe paet aenig oder man aefre maerda fon ma... 
.... gehedde 504; gemyne maer $p 0$, maegen-ellen cyd 659; onmunde usic maerda 2640; maerda gem dig 1530; syđda(n) hie da maerda geslogon 2996; Đaer waes Beowulfes maerđo maened 857; halig dryhten maerdo deme 687; gud-cyning maerda gemunde 2678; maerdo fremede 2134 (the word thus comes to mean glorious deed); haebbe ic maerda fela ongunnen on geogop e 408; similarly 2645, 2514 . ellen-maer $>u$

Glory of fortitude or glorious fortitude. In Beowulf(only): Niht-weorce gefeh ellen-maer $p$ um 828; paer he dome forleas, ellen-maerdum 1471. nid

Envy, hatred, malice, spite, ill-will. In Beowulf: Waes paes wyrmes wig wide gesyne nearofages nid 2317; Wa bid prem-de sceal purh slidne nid sawle bescufan in fyres fae $p^{m}$ 184; eawed purh egsan uncudne nid 276; wraec Wedera nid 423; sele Hrodgares genered wid nide 827; gudbill geswao nacod aet nide 2585; nipe genyded 2680; he werig-mod on weg panon nida ofercumen.. ..... feorh-lastas baer 845; hearde genearwod niđa genaeged 1439; nida craeftig 1962; cf. also $882,2170,2206,2350,2397$.

bealo-nid

Evil purpose, malice. In Beowulf (only): Bebeorh $p^{e}$ done bealo-nid, Beowulf leofa 1758; hwanan sio 
faeht aras bealo-nid biorna 2404; cf. 2714 . faer-nid

Evil hostility (T. fera danger, sudden attack; from fer to gol. In Beowulf: hwaet me Grendel hafad nit his hete pancum faernita gefremed 476 . (The word occurs in Beowulf only).

here-nid

Hostility. In Beowulf: hetenidas waeg fyrene ond faehde 153.

inwit-nid

Evil purpose. In Beowulf: sacu restan inwitni pas 1858; hio leod-bealewa laes gefremede, intitrida 1947 .

searo-nit

Crafty malice, treachery. In Beowulf (only): he searo-nidas fealh Eormenrices 1200; ic heold min tela, ne sohte seare-nidas, ne me swor fela ada on unriht. 2738 no ic wiht fram $p e$ swylcra searonida secgan hyrde, billa brogan 582; cf. also 3067 .

wael-nid

Fatal enmity, mortal fight. In Beowulf: se (s)ecg-hete apum-swerian aefter wael-nide waecnan scolde 85; syddan Ingelde weallad wael-nidas 2065 .

sorh

Care, anxiety. In Beowulf: Sorh is me to secganne ..... hwaet me Grendel hafad... faer-nida 
gefremed 473; Sorh is geniwod Denigea leodum 1322; he worna fela Sige-Scyldingum sorge gefremede 2004; He da mid paere sorhge ... gum-dream ofgeof 2468; sorge ne-cudon wonsceaft wera(s) 120; heortan sorge weallinde waeg 2463; sidra sorga 149; cf. also 2600 and 1149.

hyge-sorh

Care, solicitude. In Beowulf: paet dam godan waes hreow on hredre hyge-sorga maest 2328. inwit-sorh

Sorrow inflicted through malice. In Beowlf(only): ne him inwit-sorh on sefan sweorced 1736; ealle gebette inwid-sorge pe hie aer drugon 831. pegn-sorh

Sorrow over the loss of men. In Beown if (only): polode prydswyd pegn-sorge dreah 131.

đearf

Need, use, lack. In Beowulf: pa him waes manna pearf 201; swylce hira man-dryhtne pearf gesaelde 1250; paer de bid manna pearf 1835; Naes him aenig pearf 2493; gif him $p$ yslicu pearf gelumpe 2637; pa him waes elnes pearf 2876; ac seo ecg geswac đeodne aet pearfe 1525; swylc sceolde secg wesan pegn aet dearfe 2709; fremmad ge nu leoda pearfe; ponne his diodcyning pearfe haefde 2579; on hyra man-dryhtnes miclan pearfe; se for andrysnum ealle beweotlde pegnes pearfe 1797; cf. also 1456; 1477, 2694. 
fyren-dearf

Very great distress. In Beowulf(only): fyrendearfe ongeat paet hie aer drugon, aldor-lease lange hwile 14.

nearo-dearf

Need, pressing need. In Beowulf: nearo-pearfe dreah 422.

wyn

Delight, joy (T. veni expectation, hope). In Beowulf: nis hearpan wyn 2762; wisse he gearwe paet he daeg hwila gedrogen haefde, eordan wynne 2727; Weorod waes on wynne 2014; paer hell) aer maeste heold worolde wynne 1080; seled him on e ple eor $p$ an wynne 1730; op-paet hrefn blaca, heofones wynne, blid-heort bodode 1801 .-- the sun; hwilum hilde-deor hearpan wynne gomen-wadu grette 2107; deah-pe hine mihtig god maegenes wynnum eafe $p$ um stepte 1716; similarly 1887.

e đel-wyn

Joy in the fatherland, a splendid estate. In Beowulf(only): Nu sceal sinc-pego ond swyrd-gifu eall eđel-wyn eowrum oynne lufen alicgean 2885; he me land forgeaf, eard eđel-wy ne 2493. hord-wyn

Most precious treasure. In Beowulf (only): Hordwynne fond eald uht-sceada 2270 .

lif-wyn

Joy, or good in life. In Beowulf: he on weg losade lytle hwile lif-wynna breac 2097. 
lyft-wyn

Joy in the air. In Beowulf: (se legdraca)

lyft-wynne heold nihtes hwilum 3043. I The word

occurs only in Beowulf).

symbel-wyn

Joy in feasting. In Beowlf (only): Ga nu to setle, symbel-wynne dreoh 1782.

In review of the foregoing, certain general points may be observed. Weore, for instance, an original abstract, ${ }^{1}$ is here made concrete, but its fluid and uncertain outline enables it to be fitted over any given idea; hence it is vague and abstract in its effect. Wundur, regularly concrete in the poem, always standing for something, is still a symbol of the effect of that thing upon the mind; substituted as it is for the object itself, it, too, adds to the impression of abstractness. Once an abstract term, always more or less abstract, one might say. Thus, because it is properly an abstract formation, Wylm never attains clear concreteness, even in such a compound as fyr-wylm.

Indeed, these compounds one element of which is concrete and the other abstract are particularly in-

1. Kluge, "Nominale stammildunglehre", Sec. 104. 
dicative of the temper of the poet's mind. We are told, not that the aragon flew through the air, but that he "held joy in the air in the night time"; not that Grendel dwelt in the stormy deeps, but that he inhabited "the terror of the waters". The modifying first element does not alter the essential nature of the second. 


\section{In conalusion}

Looking back at the world of Beowulf, through the glasses furnished by the man who tells his story, we are surprised at the blanks left in the picture presented. There are no children here, ${ }^{I}$ and few women. The warrior is the only man of whom we know much certainly. Of the hall in which he lived there is little detailed description. There is no mention of the food he ate, no account of the ordinary dress of men and women. No homes of men dwelling outside the hall appear. But once is a temple seen. There is the slightest possible reference to occupations other than warfare, the merest hint at hunting, no suggestion at all of the tilling of the soil. There are no domestic animals except the horse; ${ }^{2}$ no fields of grain, no flowers, a single tree! It is a drab and somber world with only the red of blood and the yellow of gold to light up the scene. Never is the grass green or the sky blue in Beowalf. 3

Still, al though the lack of concreteness impresses the reader, he finds in it no fault. The "Innerlichkeit"

the mead-bench.

2. The single mention of the dog may be discounted, I think, for there is only an implication that it was a hunting dog nd not a wild beast.

3. Mead, "Color in OE. Poetry", Publ. Mod. Iang. Assoc. $\mathrm{XIV}, \mathrm{p} 169$. 
more than compensates for all the concrete details that we miss. The life story of a hero who could with calm steadiness admit that "Wyrd goes ever as it must", $I_{\text {who }}$ is not afraid to boast,"I will show knightly courage, or in this mead-hall pass my latest day", who ruled his people well for fifty winters and then left them with, "Fate has swept all my kinsfold off, undaunted nobles, to their doom. I must go after them" -.- this tale, in short, of the hero ideal of an old time and people asksfor no elaboration of concrete detail to make it convincing. It touches an epic strain in the minds of men which is more real to them than the world of sense, a quality of mind wi thout which no epic could ever be.

1. Dootor Hall's translation is used here. 


\section{BIBIIOGRAPHY}

Balawin, James M.

Dictionary of Philosophy and

Psychology. New York, London.

The Macmillan Co. 1901-0b.

Bosworth, Joseph. An Anglo-Saxon Dictionary. Ed. and enl. by $T$. Northcote loller.

Oxford. The Clarendon Press

$1882-98$.

Brandl, Alois I. Geschichte der altenglischen

Literatur. Strassburg, 1908.

Chadwick, Hector, M. 1. The Heroic Age. Cambridge

University Press, 1912.

2. The Origin of the English

Nation. Cambridge University

Press, $190 \%$.

3. Studies in Anglo-Saxon In-

stitutions. Cambridge University Press, 1905.

Fick, August

Vergleichendes worterbuch der

Indogermanischen Sprachen.

Dritter Teil, Wortschatz der

germanischen Spracheinheit,

ganzlich umgearbeitet von Alf

Torp. G8ttingen, 1909. 
Forster, liax

$$
\text { Golther, Wolfgang } \begin{aligned}
& \text { Handbuch der germanischen } \\
& \text { Mythologie. Leipzig, } 1896 .
\end{aligned}
$$

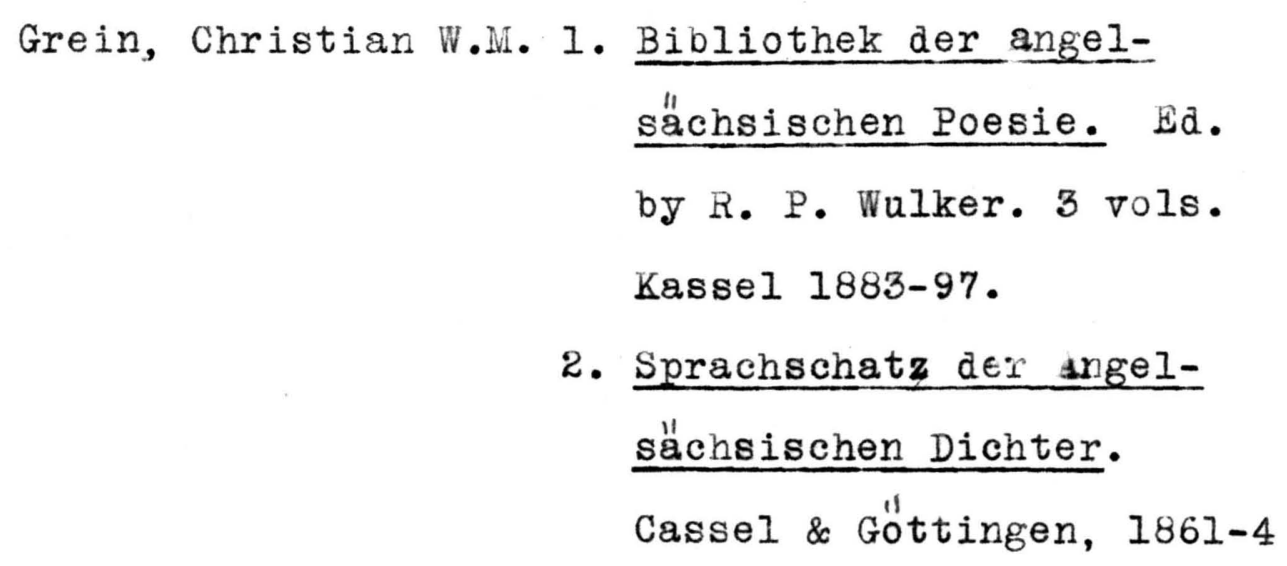

Gummere, Francis B. The Anglo-Saxon Metaphor. Halle, 1881.

2. The Oldest English Epic;

tr. in the original meters.

New York. The Macmillan Co.

1909-10. 


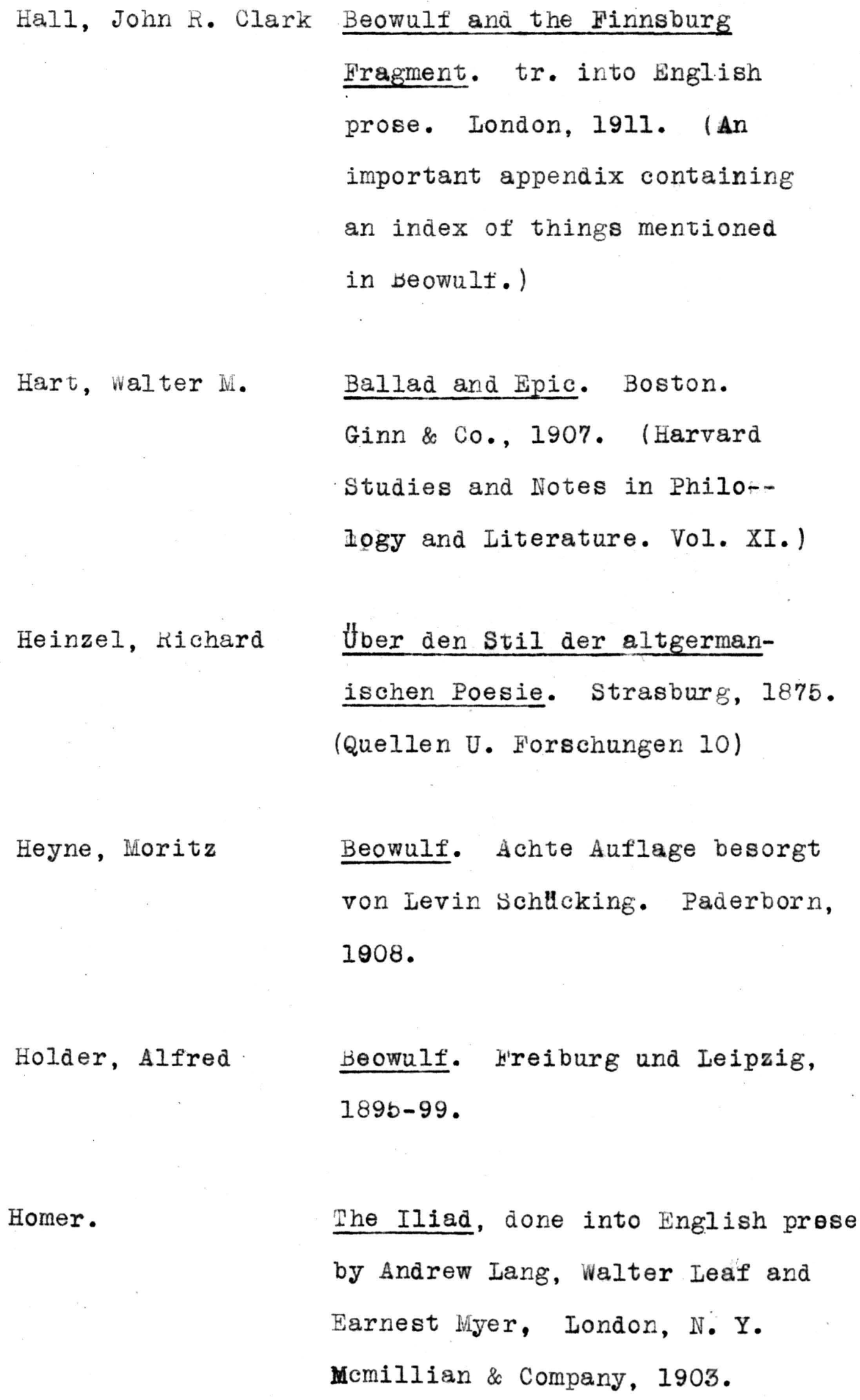

Homer.

The Iliad, done into English prese

by Andrew Iang, Walter Ieaf and

Earnest Myer, Iondon, N. Y.

Mcmilian \& Company, 1903. 
Hoops, Johannes

KArre, Kar 1

Keller, May
1. Reallexilson der germanischen

Altertumskunde (Work incomplete.

Last issued Dritter Banā, Erste

Lieferung.)

2. Waldbaume und Kultur. Pflanzen

im Germanischen Altertum.

Strassburg, 1905.

Nomina Agentis in 0ld English.

Dissertation Upsala 1915; as

review by Leonard bloomfield

for the Journal of English and

Germanic pilology (v. 1b, p.143)

The Angl0-Saxon Weapon Names. Anglistische Forschungen, Heft 15.

Kistenmacher, Kichard. Die wortlichen Wiederholungen in Beowulf. Greifswald, 1898.

Kluge, Friedrich Nominale Stammbildungslehre der

altgermanischen Dialekte. 2

Autl. Halle, 1899.

Krackow, ottc

Die Nominalcomposita als Kunst-

mittel im altenglischen Epos.

Weimar, 1903. 
$\begin{array}{ll}\text { Lawrence, W. W. } & \text { The Haunted Were in Beowulf. } \\ & \text { Publications of the Wodern } \\ & \text { Language Ass'n. V. 27, p. 208. } \\ \text { Mead,Wm. E. } & \text { Color in Old English Poetry. } \\ & \text { Publications of the Modern } \\ & \text { Language Assn. V. 14, p. 169. } \\ & \text { Aesthetische Studien zur an- } \\ \text { Merbot, Reinhold } & \text { gelsdschsischen Poesie. Breslau 1883. }\end{array}$

Muller, Sophus 0. I'Europe Prehistorique; tr. du

danois avec la collaboration de

l'auteur par Emmanuel Philipst. Paris, $190 \%$.

Paul, Herman

Grundriss der germanischen

Philogie.

Sarrazin, G.

Der Schauplatz des ersten Beowulf

liedes und die Heimat des Dichters.

(Beitr명 p 158 ff.)

Scheinert, $\mathrm{M}$.

Beirtage
Die Adjectiva im Beowulf als

Darstellungsmittel. Halle, 1905. 
Schnepper, $0 . \quad$ Schiffe und Schiffsteile im Altenglischen. Diss. Kiel, 1908.

Schrader, Otto. Reallexikon des indogermanischen Altertumskunde. strasburg, 1901.

Sedgfield, W. J. Beowulf. Manchester. The University Press, 1913.

Sedgwick, Alfred The Use of Words in Keasoning. London, 1901.

Sievers, Ḣ.

Altnordisches im Beowulf.

(in Beitrage 12, 168)

Stjerna, Knut

Essays on Questions Connected with

the 0ld English Poem of Beowulf.

tr. and ed. by John K. C. Hall.

Coventry, 1912. (An appendix con-

taining Dr. Hall's Index of Thing:s.)

Tolman, Albert H. The Style of Anglo-Saxon Poetry.

Transactions of the Modern Ianguage

Ass'n. Vol. III. Baltimore, 1887.

West, Alfred S. An English Grammar for Beginners.

Cambridge, The University Press, 1900. 
Wyatt, Alfred J. Beowulf with the Finnsbury

Fragment. New Edition, re-

vised with introduction and

notes by $R$. W. Chambers,

Cambridge, The University

Press, 1914. 
Grateful acknowledgement is here to be made to the members of the English faculty of the University of Missouri, to Dr. Belden especially, and also to Dr. Fairchild and Dr. Rankin, for assistance so great and covering so long a tine that it cannot well be stated. The writer is conscious that much which seems to her most completely her own is doubtless, after all, only the echoing of a suggeation given by one of her teachers. 


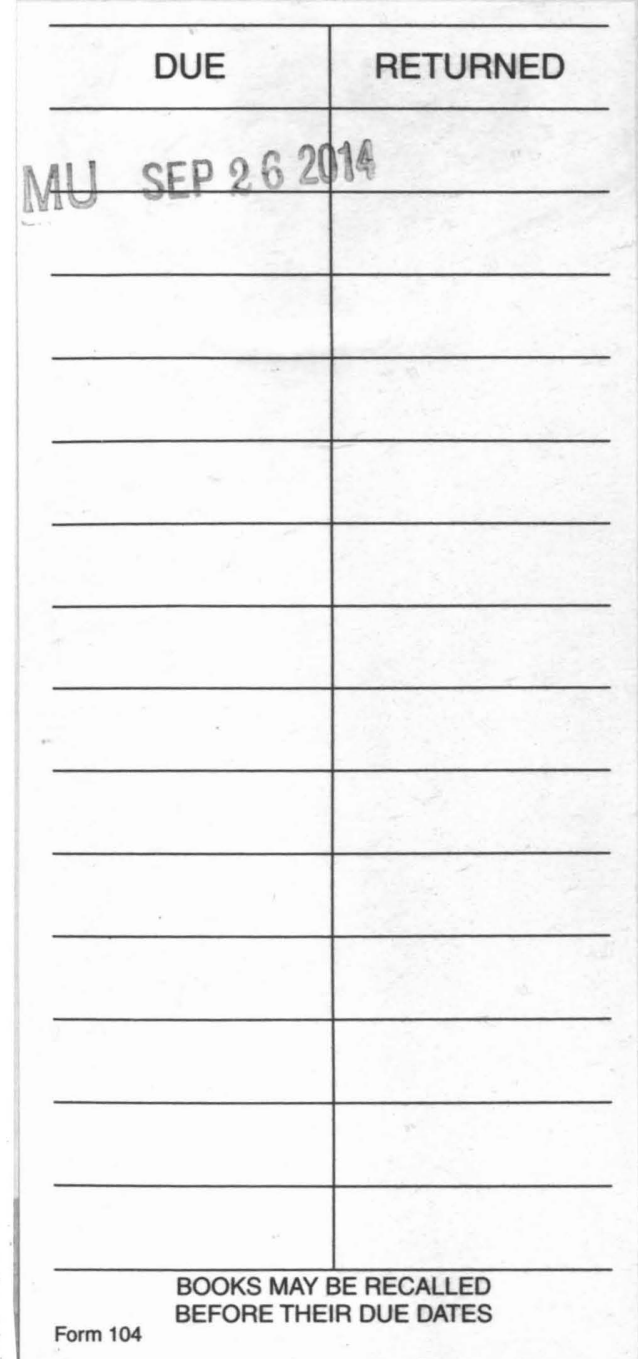


$x^{2}$

4.

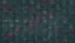


MU Li braries

University of Mi ssouri-.-Col umbia

Digitization Information Page

Local identifier ConcretesabstractsBeowulf

Citation (first title in volume)

AUTHOR

TI TLE

I MPRINT

Capture information

Date captured

Scanner manufacturer

Scanner model

Scanning system software

Optical resolution

Color settings

File types

Notes

Source information

Content type

For mat

Source I D

Notes
Cratty, Estella Faye.

Concretes and abstracts in the 1916 .

old English epic Beowulf.

$06 / 2014$

Zeutschel

OS 15000

Omniscan v.12.4 SR4 (1947) 64-bit

$600 \mathrm{dpi}$

24 bit color

$\mathrm{tiff}$

some page curvature due to tight binding.

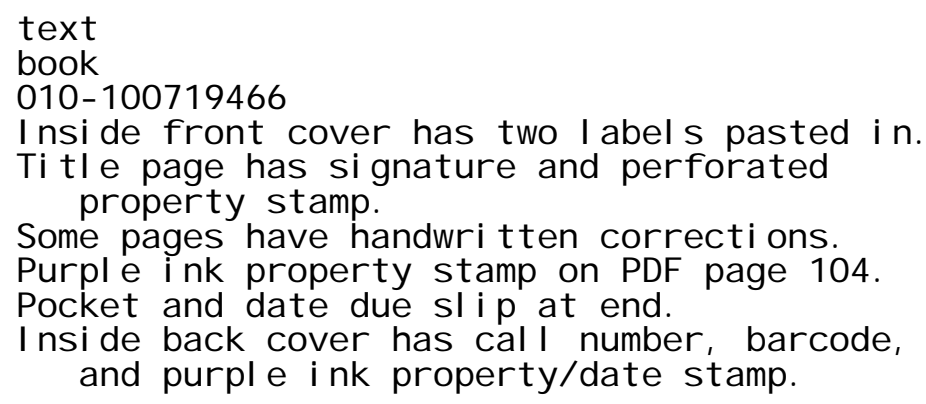

Derivatives - Access copy

Compression

Editing software

Editing characteristics

Resolution

Color

File types

Notes
Tiff: compression: 1

Adobe Photoshop CS5

Pages cropped and resized.

$400 \mathrm{dpi}$

gray scale / color

$p d f$

Pages typed single-sided. Blank pages removed from access copy. 